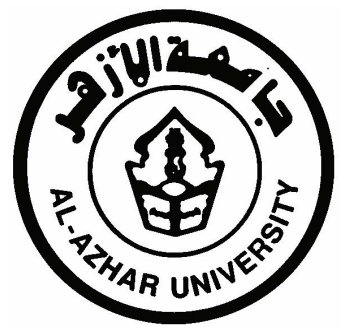

$$
\begin{aligned}
& \text { جامعست الأزهــــر } \\
& \text { كليـت أصــول الديـن } \\
& \text { والدعوة الإسلاميتَ بالمنوفيت }
\end{aligned}
$$

$$
\text { هزاعم أفطاء الكاتب }
$$

\title{
إعار الركتور
}

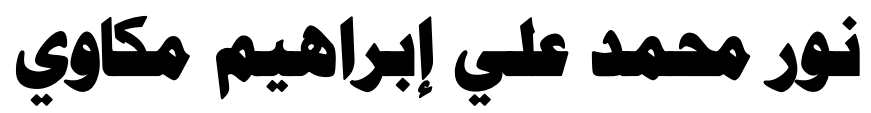

$$
\begin{aligned}
& \text { أستاذ مساعد بقسم التفسير وعلوم القرآن } \\
& \text { كلية أصول الدين والدعوة } \\
& \text { فرع جامعة الأزهر بالزفازيق }
\end{aligned}
$$





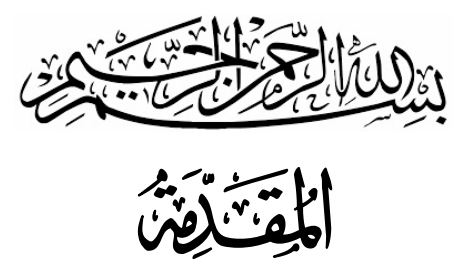

الحمد لله الذي صان كتابه من عبث العابثين، وتحريف المبطلين، وتكفّل

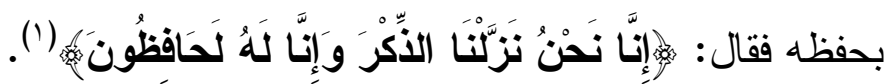

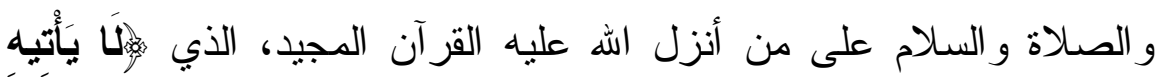

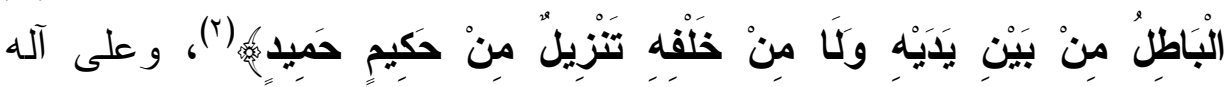

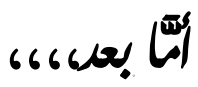

وصحبه أجمعين.

فلأن القرآن الكريم هو أصل الدين، ومصدر الإسلام، فقد حاول الطاعنون في القرآن منذ زمن بعيد التشكيك فيه مستغلّين ما وجدوه من روايات ضعيفة، و آثار و اهية، وموضو عات كاذبة، وذللك ليلبسو ا على الناس دينهم، ويشككو ا في قر آنهم، ويقنعو ا مرضى القلوب أن يد التحريف قد أصابته، وغير ذلك مما يفترونه ويز عمونه.

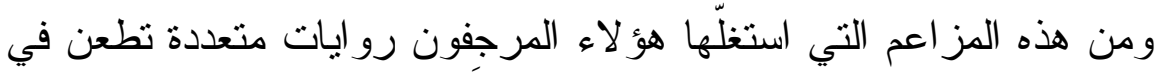
القرآن، وتز عم أن كُّاب المصحف عند جمعهم للقرآن أخطأو آفي كتابة كلمات و ألفاظ، فحرّقو ا وغيّرو ا، وز ادو ا، ونقصو ا. وحول هذه المز اعم يدور موضوع هذا البحث الذي سميته: المز اعم أخطاء الكاتب في القرآن - عرض ونقده.

$$
\text { (1) سورة الحِجْر الآية: } 9 .
$$




\section{أسباب اختيار الموضوع وأهميته:}

1- جمع ما تفرق حول هذا الموضوع في بحث مستقل يفي بالغرض، ويحقق فائدة أكثر .

r- مشاركة من سبقنا في الرد على بعض هذه المز اعم، دفاعًا عن القر آن. r- الحاجة الماسّة اليوم إلى الردّ على هذه المز اعم و غير ها؛ وذلك لانتشار

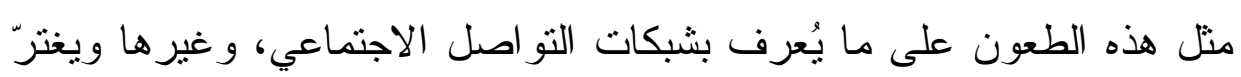

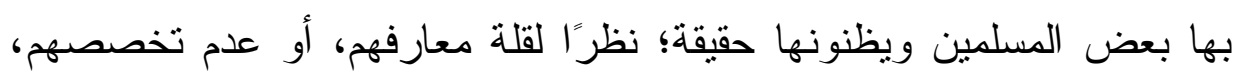
ونحو ذلك.

ع- يبان حقيقة هذه المز اعم، و أنها مصدر من المصادر الضعيفة التي اعتمد عليها الطاعنون في القرآن.

هذا، وقد قسمتُ البحث إلى: مقدمة، وتمهيد، وأربعة مباحث، وخاتمة. المقدمة: وتشتمل على أسباب اختيار الموضوع و أهميته، وخطة البحث. التمهيذ: ويشتمل على مسائل متعلقة بالبحث. المبحث الأول: كُتّاب المصحف وعنايتهم بالقرآن. المبحث الثاني: ما ورد حول خطأ الكاتب في تبديل كلمات، وحروف. ويشتمل على ثُلاثة مطالب:

المطلب الأول: ما ورد حول خطأ الكاتب في تبديل كلمات بكلمة. المطلب الثاني: ما ورد حول خطأ الكاتب في تبديل كلمة بكلمة. المطلب الثالث: ما ورد حول خطأ الكاتب في تبديل كلمة بحرف. المطلب الر ابع: ما ورد حول خطأ الكاتب في تبديل بعض الحروف. المبحث الثالث: ما ورد حول الزيادة، والنقص. ويشتمل على مطلبين: المطلب الأول: ما ورد حول زيادة حرف. 
المطلب الثاني: ما ورد حول نقص كلمة.

المبحث الر ابع: ما ورد حول خطأ الكاتب من الناحية النحوية.

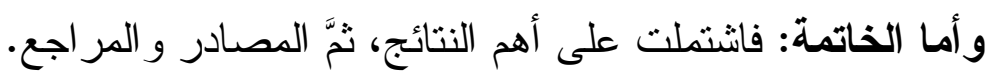

\section{مدود البمث:}

1- هذا البحث يدور حول جمع الألفاظ و الكلمات القر آنية التي وردت في بعض الأقو ال المنسوبة لبعض الصحابة أو التابعين، و التي فيها: ״هذا خطأ من

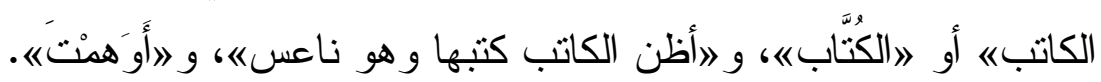
ويلحق بها ما فيه إثـارة و اضحة إلى خطأ الكاتب، وذللك في الآتي:

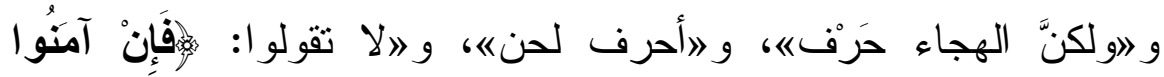

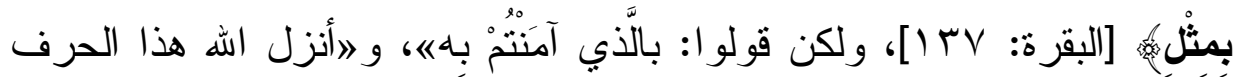

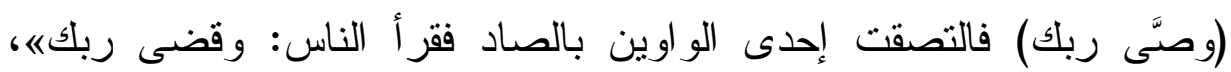

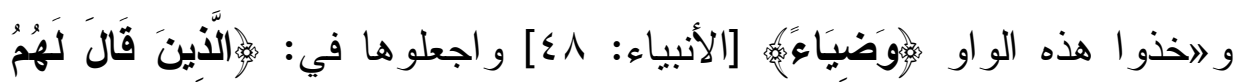

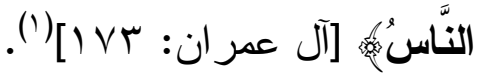

أمَّا باقي المز اعم و الطعون التي تطعن في القرآن، أو رسم المصحف خاصة - و التي ليست فيها هذه الأمور التي ذكرتها - فلا تدخل في موضوع البحث.

(1) حصرتُ هذه المو اضع من: الإتقان في علوم القر آن للسيوطي (T/Y / Y (T)، وما بعـدها،

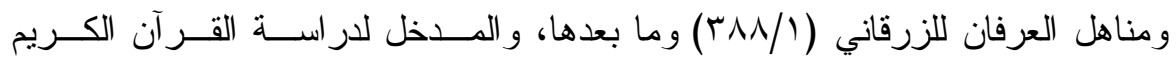

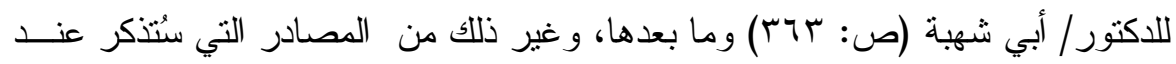
توثيق هذه المز اعم، ودر استها إن شاء الله تعالى. 
r- الردّ على هذه المرويّات ونقدها من خلال كُبت التفسير، وعلوم

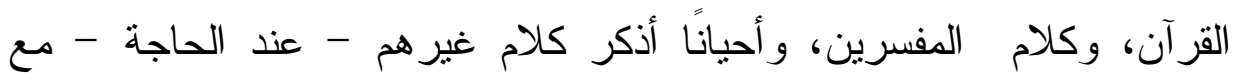
دراسة موضع الطعن في الآية وتوجيهه التوجيه السليم، إن استدعى الأمر ذلكانك.

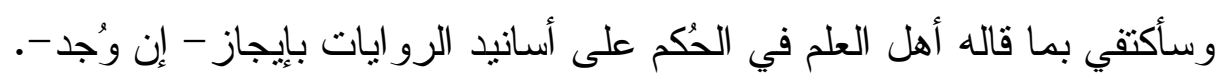

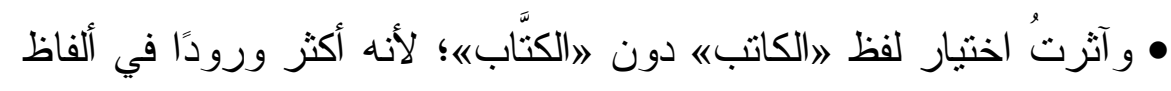

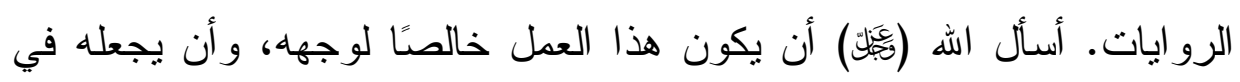

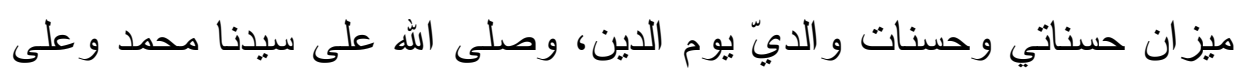

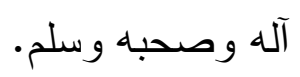




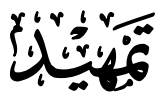

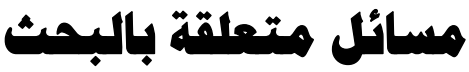

\section{المسألة الأولى: همطالمات البمث:}

1 - معنى مزاعم: تدور مادة ازعَمش في اللغة حول أمور منها: القَّل، ومنه:

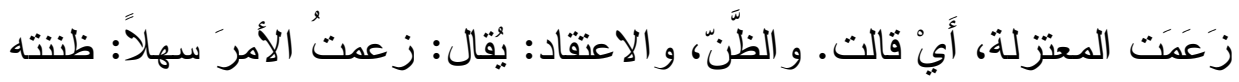

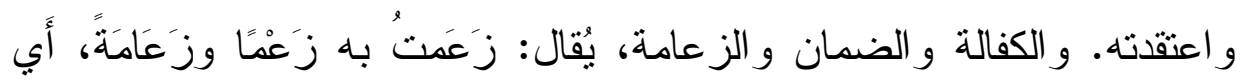

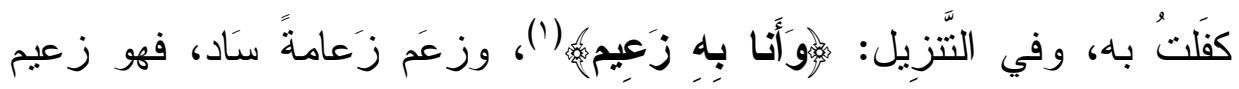

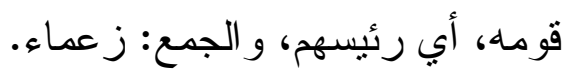
و الكلام الكذب، أو الذي فيه شكَّ وارتياب، أو الذي لا يُونثق بها، يُقال:

$$
\text { تز اعمَا، أي: تحادثا بِما لا يوثق به من الأَحاديث (r). }
$$

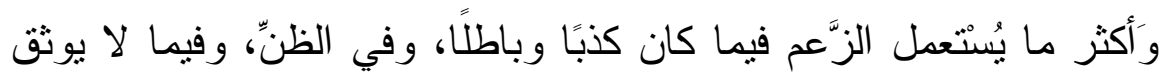
بها من الأَحَادِيث. و هذا هو الذي يتعلق بموضو ع البحث.

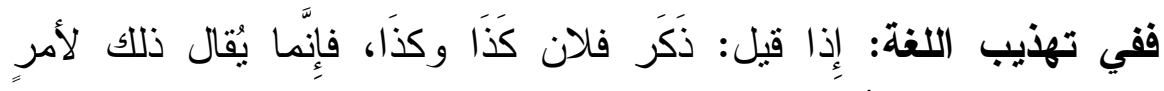

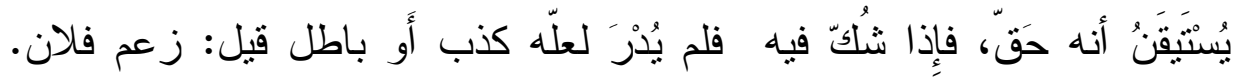

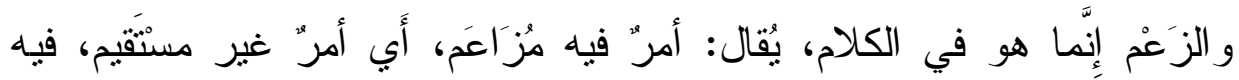

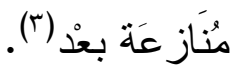

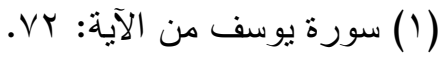

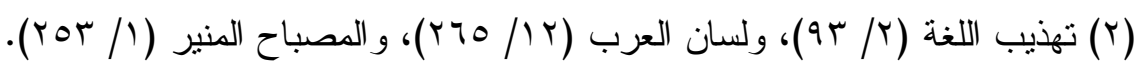

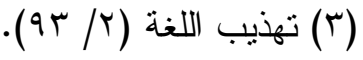


وفي المفردات للراغب: الزَّعْم: حكاية قول يكون مظنّة للكنب، ولهذا جاء

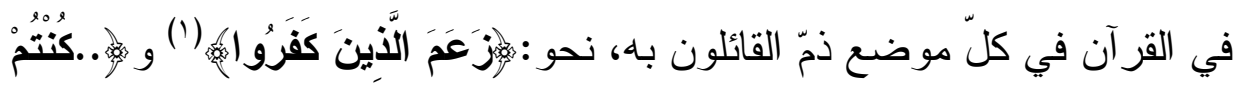

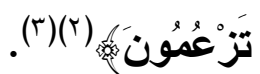

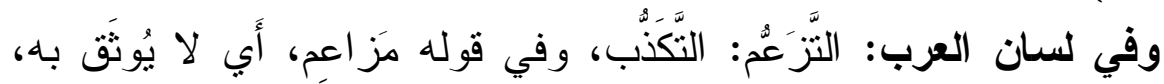

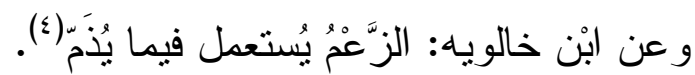

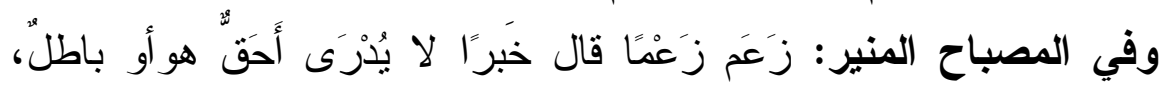

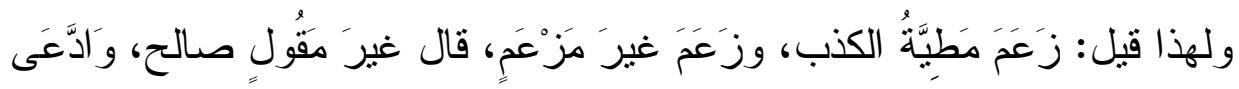

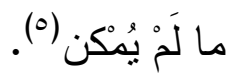
وفي ضوء ما سبق: نسنطيع القول أن المقصود بالمزاعم في موضوع البحث: تلك الأقوال المختلقة المخالفة للحقّ والواقع، التي استُغلتّ للطعن في

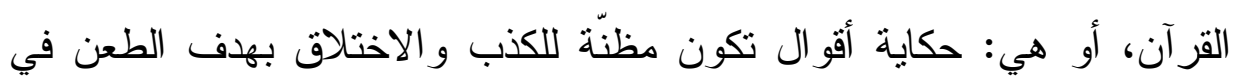

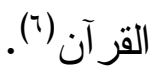

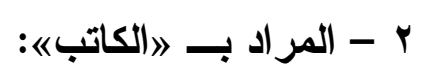

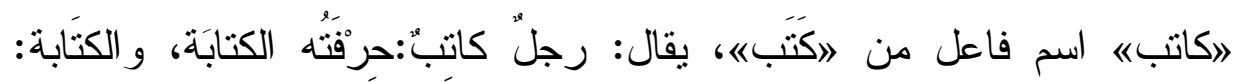

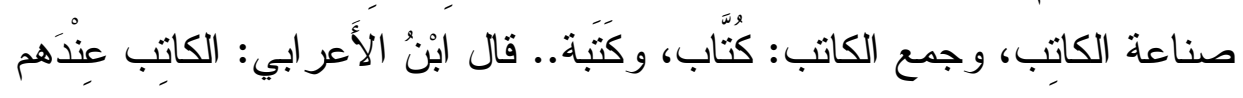

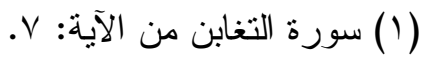

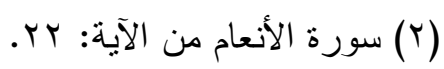

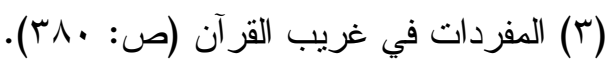

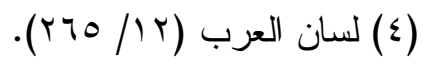

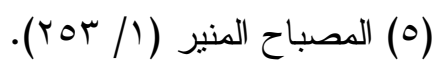

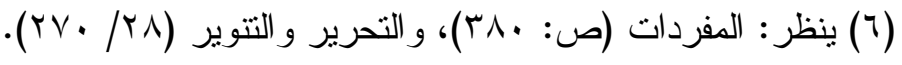




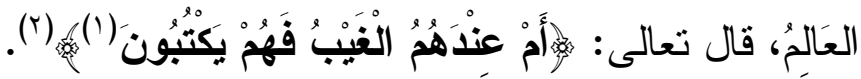

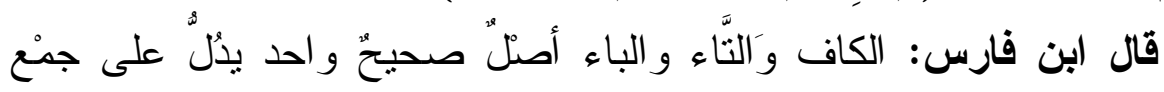

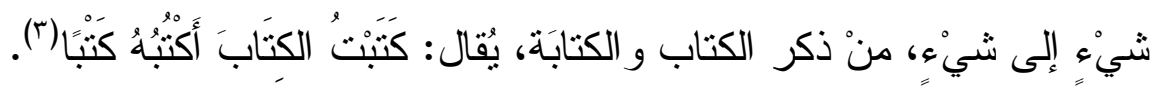

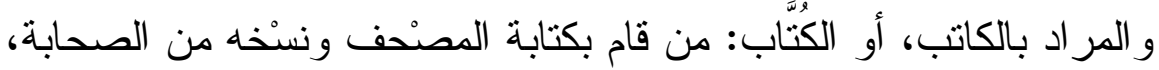

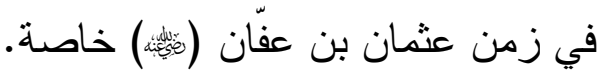

فالمقصود بعنوان البحث: دراسة الأقوال المختلقة المنسوبة لبعض الصحابة و التابعين التي تُفيد أن الكاتب قد أخطأ في كتابة بعض ألفاظ القرآن عند جمع عثمان.

\section{المسألة الثانية: هبّية قول المهابي، وقول التابهي:}

هذه المزاعم التي يدور حولها هذا البحث منسوبة لبعض الصحابة

و التابعين، لذا سنتكلم عن حجّية قول الصحابيّ، وكذا قول التابعي. • أمَّا عن قول الصحابي: فقيه خلاف بين أهل العلم، نذكر منه ما يلي بايجاز :

• منهم من قال: أنه حجة، بشرط ألا يُخالف نصنَّا، و لا صحابيًّا آخر ، فإن خالف نصنًا أُخذ بالنص، و إن خالف صحابيًّا آخر أُخذ بالر اجح. و الأكثرون على ولى

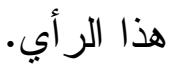

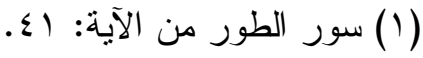

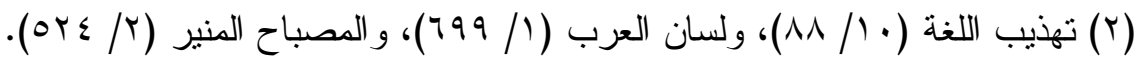

$$
\begin{aligned}
& \text { (r) مقاييس اللغة (101/ (101). }
\end{aligned}
$$


ومنهم من قال: الحجة من أقوال الصحابة قول أبي بكر وعمر (مثلَّمَ)

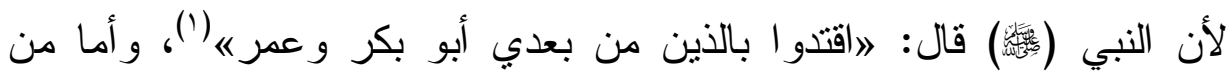

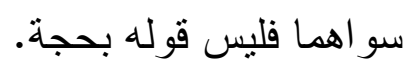

ومنهم من قال: إن قول الصحابي ليس بحجة؛أنه بشر ويصيب

ويخطئ (r)

و وأمَّا عن قول التابعي: فهناك من قال يجوز الأخذ به، وهناك من قال لا يُؤخذ به، لأن التابعين ليس لهم سماع من الرسول،ولم يشاهدوا القرائن

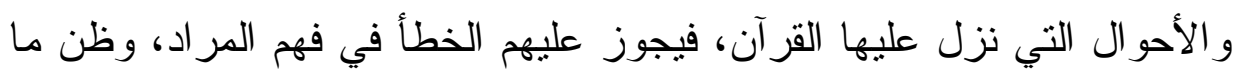

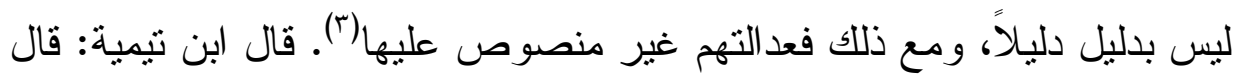

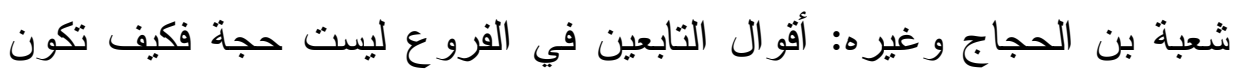

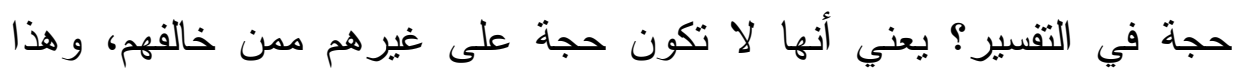

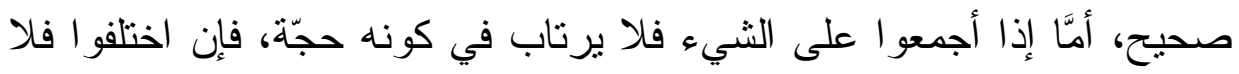
يكون قول بعضهم حجّة على بعض و لا على من بعدهم (ई).

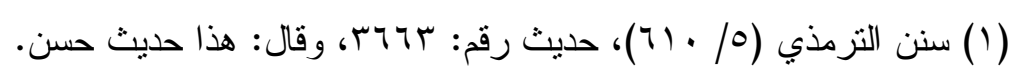

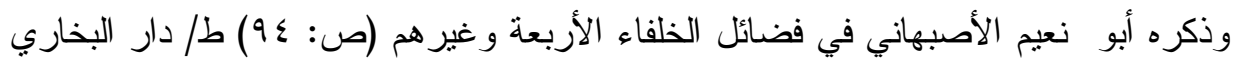

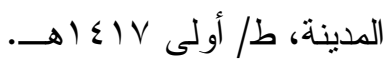

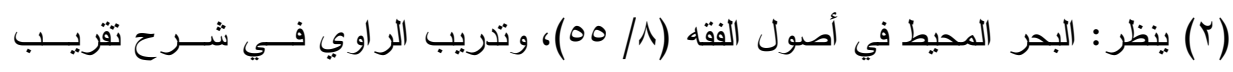

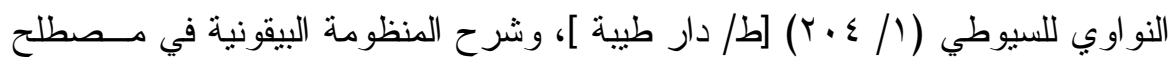

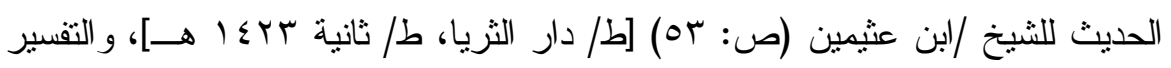

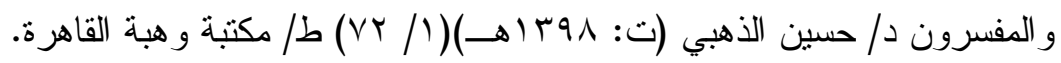

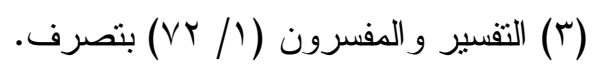

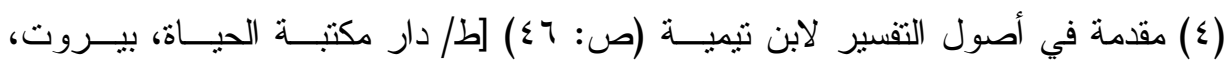

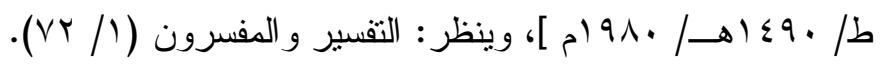




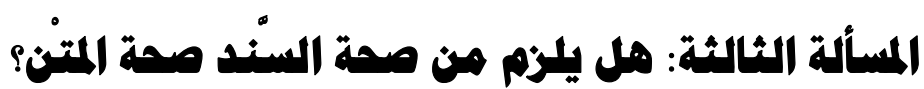

ما قرره المحدِّتون أنه لا بلزم من صحة السند صحة المتن، و لا يلزم من

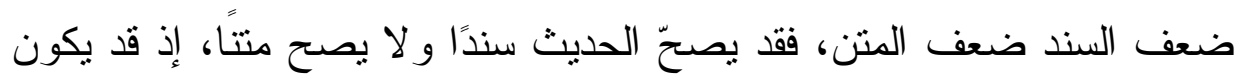

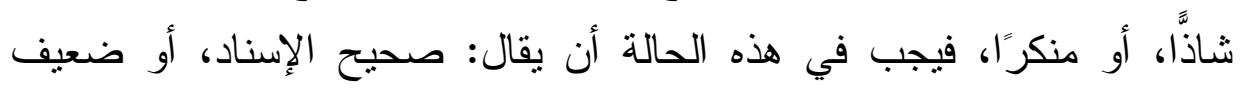
الإسناد، ونحو ذلك.

وقد يضعَف السند ويصحّ المنن لوروده من طريق آخر، فليس لنا أن نقول هذا ضعيف، ونعني به ضعف منت الحديث بناء على مجرد ضعف ذلك

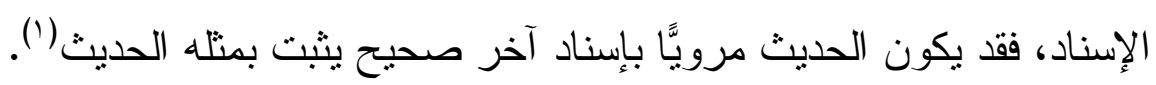
• كما أنه لا خلاف في أن الحديث إذا استوفى شروطه الموجبة لصحتهسندًا ومتتًا- فإنه يحكم له بالصحة، ويُقال عنه حديث صحيح، بمعنى أنه قد تحققت فيه جميع شروط القبول التي تؤهله لجو از الحكم عليه بالصحة، و إن فقد شرطًا من تلك الشروط أو أكثر فإنه يضعف بذلك، و الحديث إنما يصح بمجموع تؤه أمور منها: صحة سنده وانتفاء علته، وعدم شذوذه ونكارته، وأن لا يكون

راويه قد خالف التقّاتَ، أو شَذَّ عنهم (r).

(1) علم التخريج ودوره في حفظ السنة النبوية د/ محمد محمود بكار (ص: 990) [ط/ مجمع

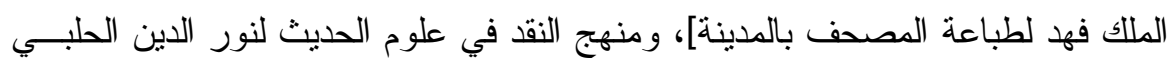

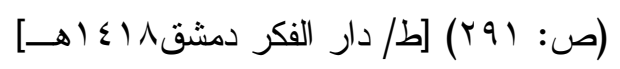

(Y) علم التخريج ودوره في حفظ السنة (ص: می)، وينظر : معرفة أنواع علوم الحديث لابن

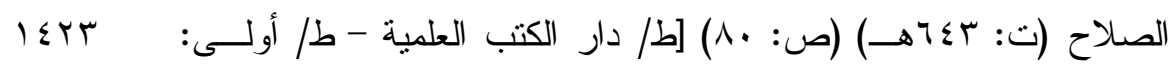

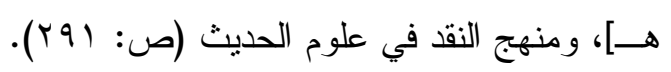




\section{المبحث الأول \\ كُتَب المصف وعنايتهم بالقرآن}

نظرًا لأن المز اعم الواردة في هذا البحث تطعن في كُتاب القرآن وتتههمج

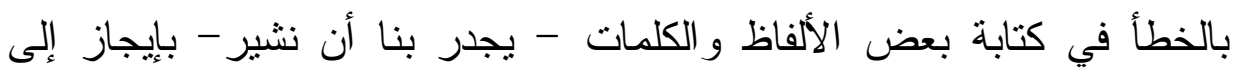

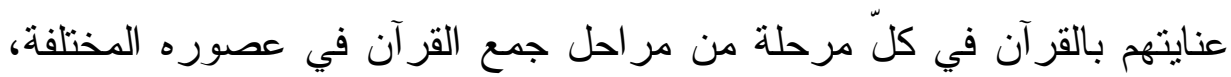

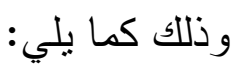

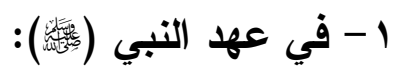

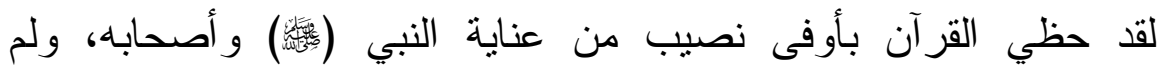
تصرفهم عنايتهم بحفظه و استظهاره عن عنايتهم بكتابته ونقشه، ولكن بمقدار ما

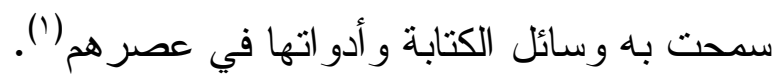

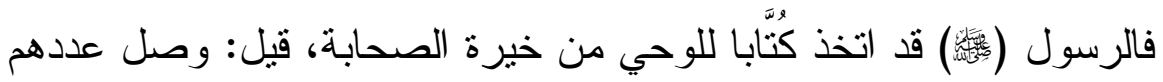

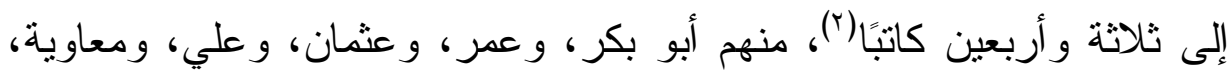

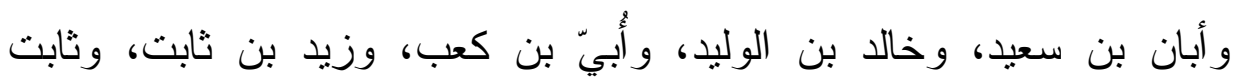
بن قيس، و المغيرة بن شعبة، و الزبير بن العو ام و وغير هم كثير .

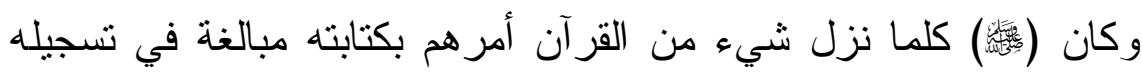
وتقييده، وزيادة في التوثق و الضبط و الاحتياط (ّ).

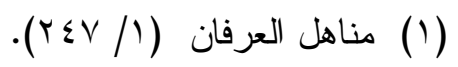

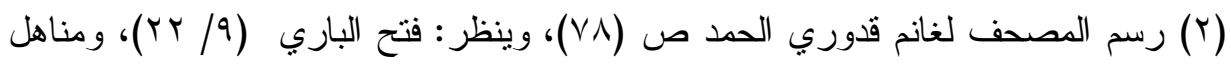

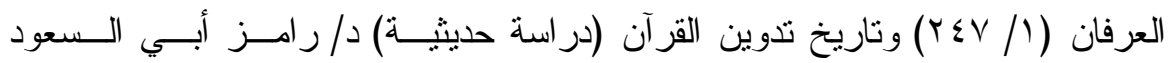
ص (109) [بحث منشور بمجلة جامعة الإمام بالسعودية]

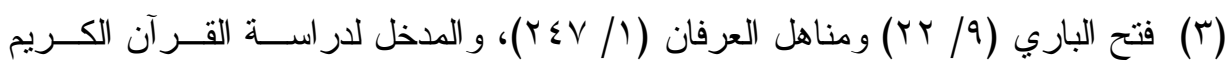

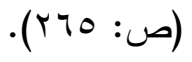




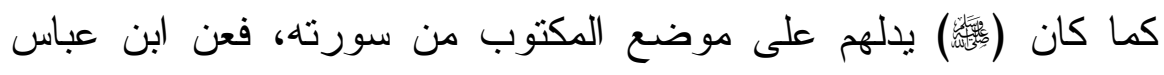

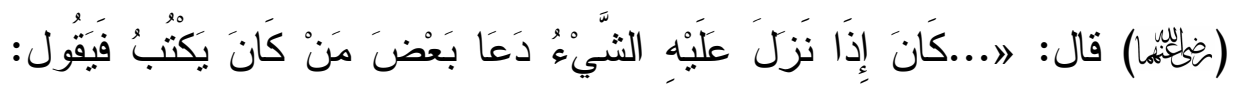

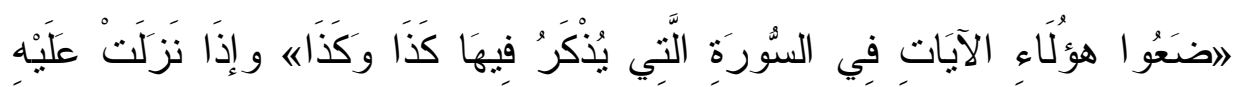

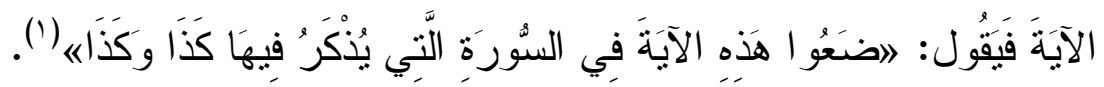
وكتب الصحابة القرآن الكريم فيما تيسّر لهم من العُسب (جريدة النخل المستقيمة يقشط قوسها)، و اللخاف (حجارة بيضاء رقيقة)، و الرقاع (قطعة من

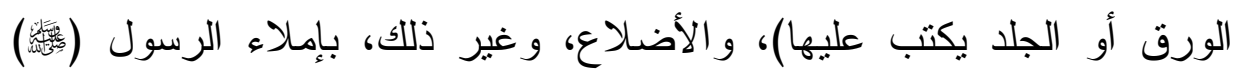
عليهم مباشرة:(r). وكان (2) لا يكتفي بإملاء القرآن على أصحابه، بل كان بر اجعهم فيما يكتبون، فإن وجد بعض خلل أو سقط أقامه وصحّحه (َّ).

( (1) جز ء من حديث أخرجه أبو داوود في سننه (Y/ • 9)، كتاب: الــصلاة، بـاب: الجهـر

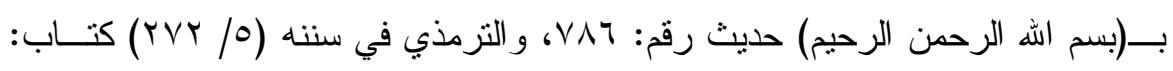

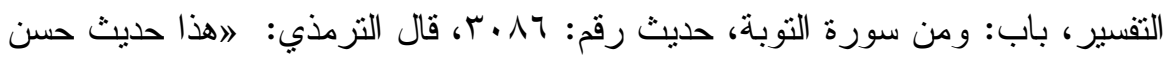

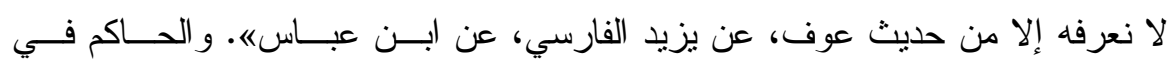

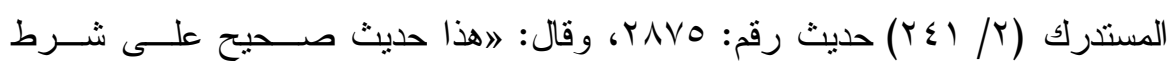

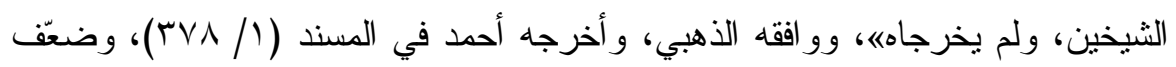
إسناده الثيخ شاكر في حاثية المسند.

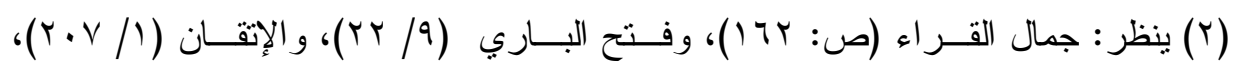

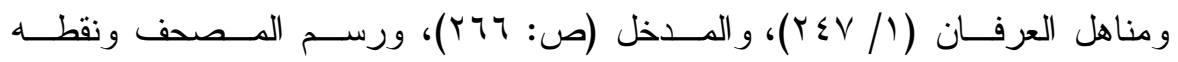

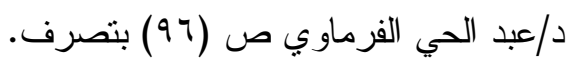

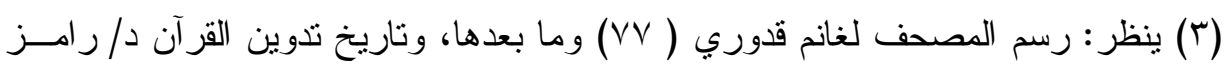

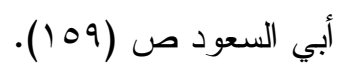




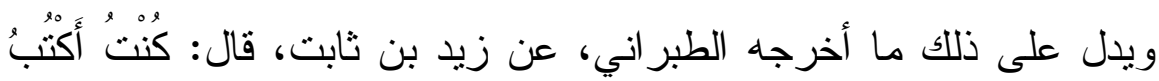

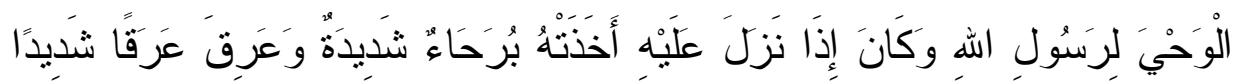

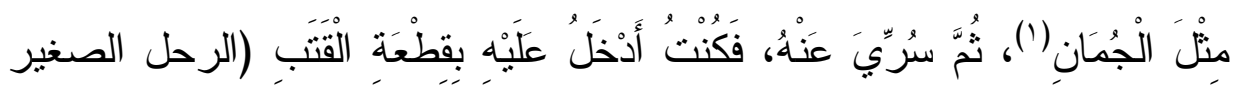

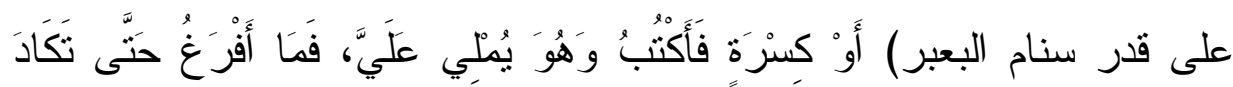

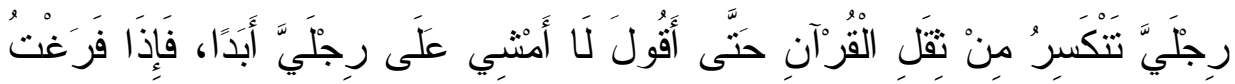

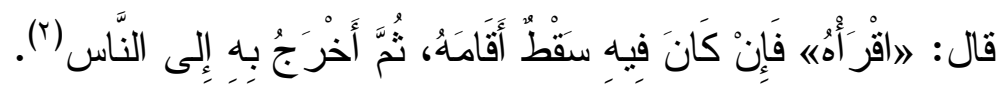

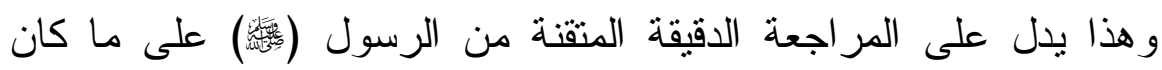

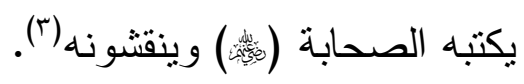
كما كان في بعض الأحيان تُعاد كتابة الآية أو الآيات مرة، أو مرات إذابها لزم الأمر،كأن تعاد من أجل الترتيب، ونحو ذللك، ومن الضروري أن الصحابة

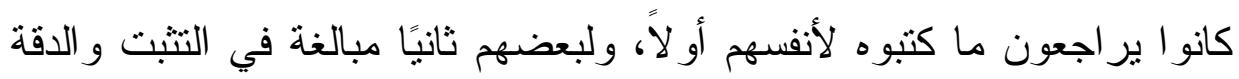

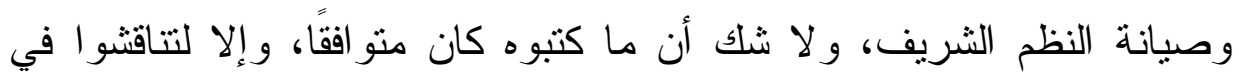

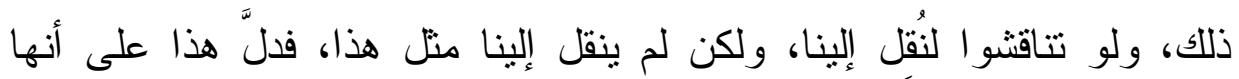

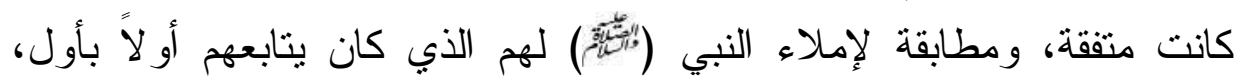
ويملي عليهم بنفسه مباشرة:(ఓ).

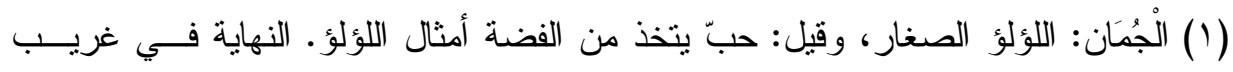

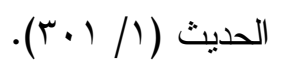

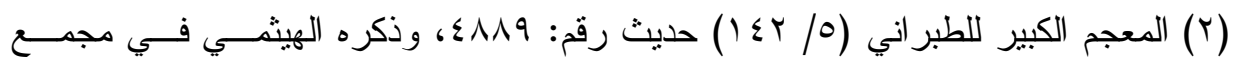

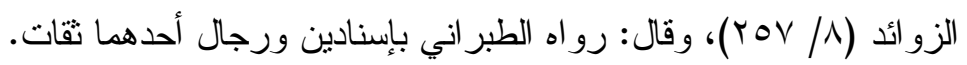

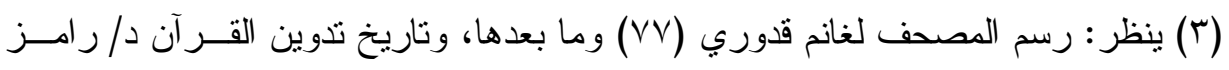

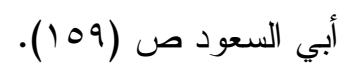

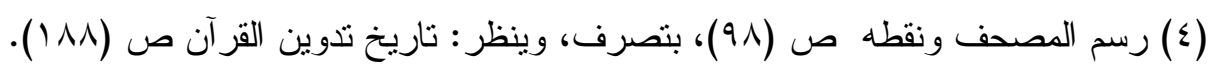




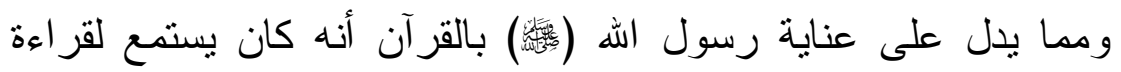

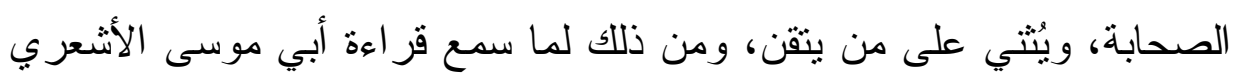

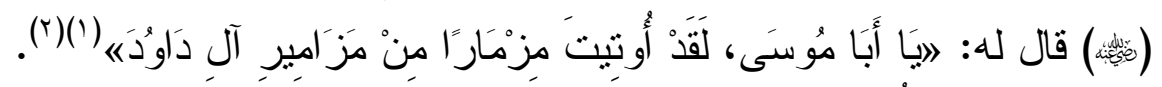

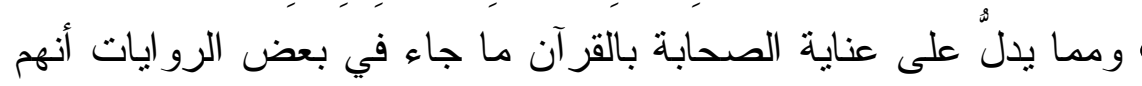

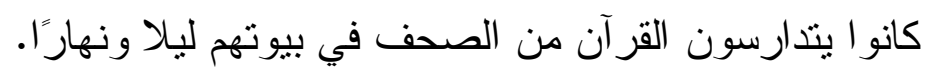

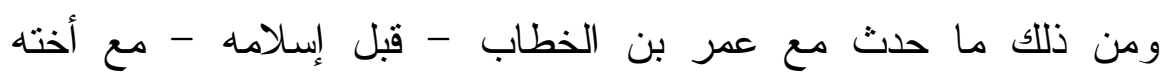

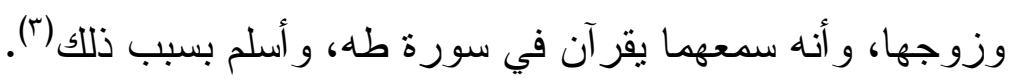

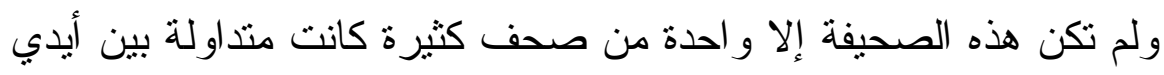

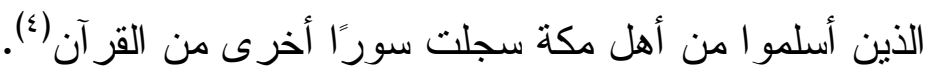

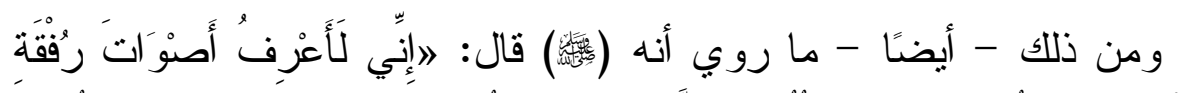

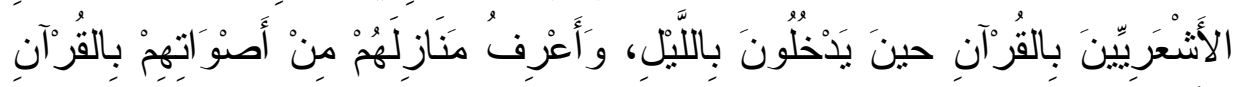

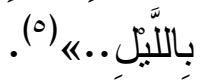

(1) أخرجه البخاري (1/ 190/) كتاب: فضائل القرآن، باب: حُسن الصوت بالقراءة للقر اءة

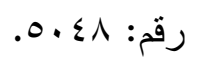

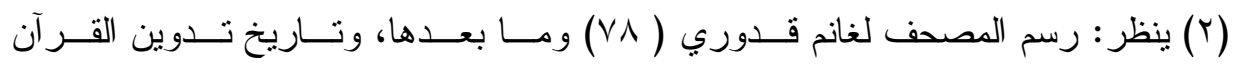

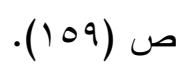

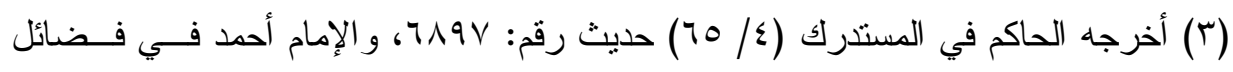

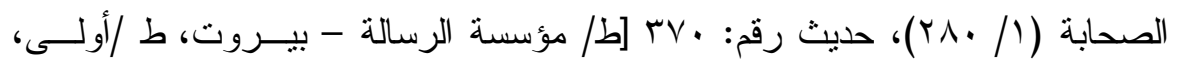

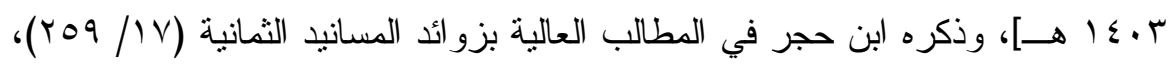

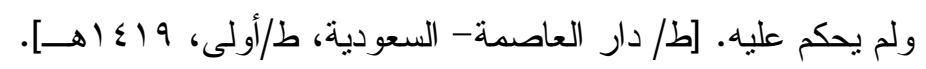

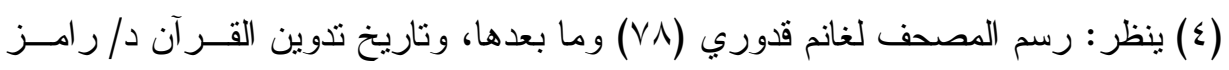

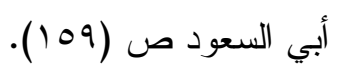

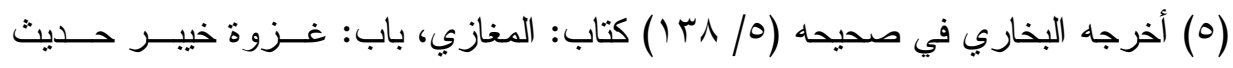

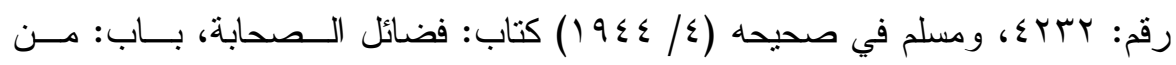

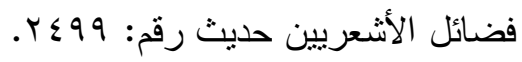




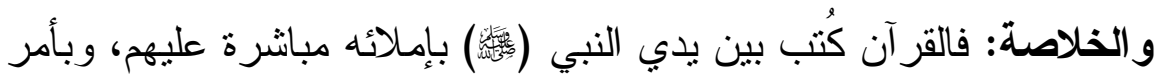

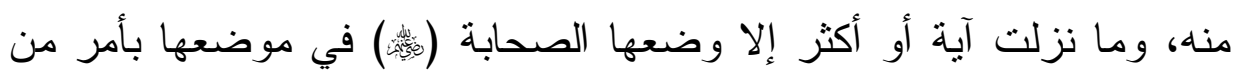
النبي (ئس وحفظ عدد كبير من صحابة رسول الله القرآن الكريم حفظًا منقنًا - كما أُنزل- سورًا و آيات وكلمات وحروفًا، فما ضاع منهم حرف واحثة واحد، ومات

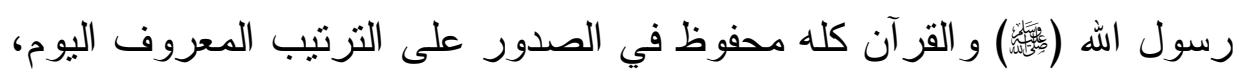

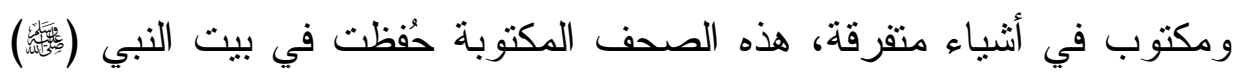

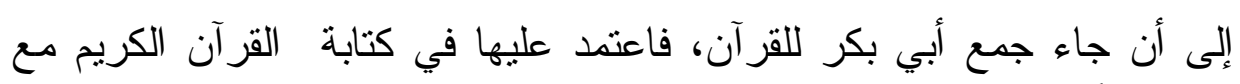

حفظ الحُفَّاظ (').

\section{r - في عهد أبي بكر الصديق (نبئن):}

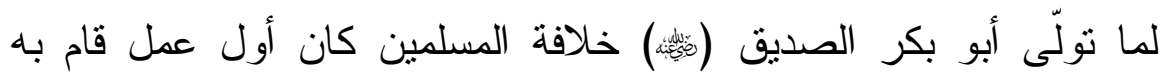
محاربة أهل الردة و القضاء على هذه الفتنة، ولما كانت موقعة اليمامة استشهي

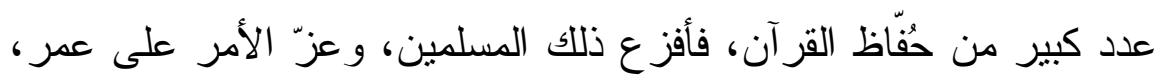

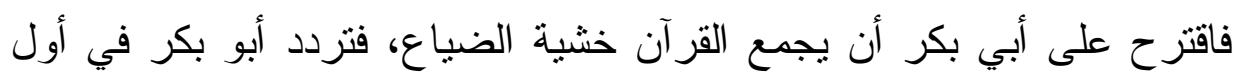

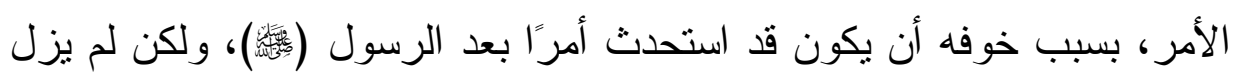

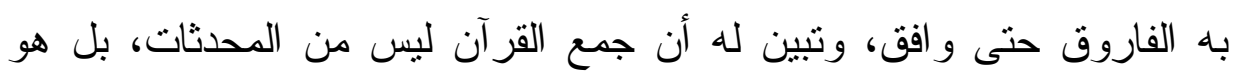

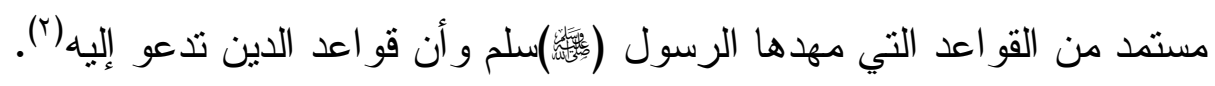
فأرسل الصدّيق إلى زيد بن ثابت، وندبه للقيام بهذا العمل الجليل لأنه من

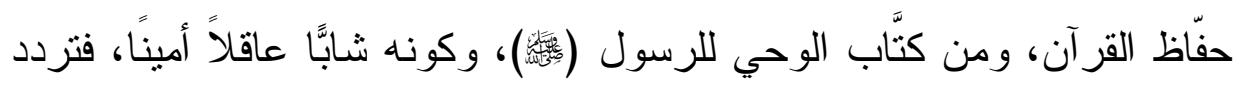

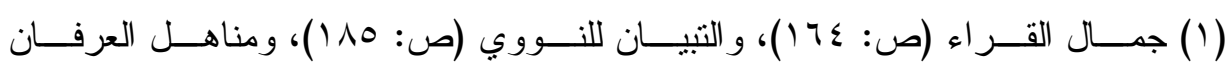

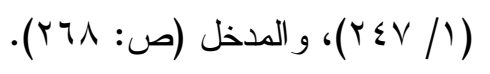

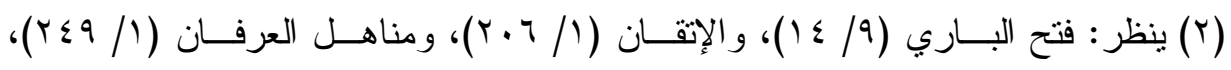

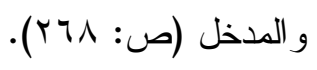


زيد بن ثابت في بداية الأمر، ثم بيّن له أبو بكر وجه الصواب، و اقتتع بذلك ثم تتبعو ا القر آن فجمعوه من الأثياء التي كتب فيها منل العُسب و اللخاف و غيرها، مع حفظ الحُفَّاظ، ثم بعد الجمع قوبلت تلك الصحف بما تستحق من عناية فائقة،

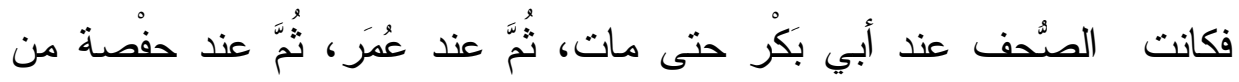
بعده (') ( n)

وكان من شدة عنايتهم بالقرآن أنهم اتبّوا أوثق طريقة لجمع القرآن فيها حذر دقيق، فلم يكتف زيد بما حفظ في قلبه و لا بما كتب بيده، ولا بما سمع بأذنه، ولكن اعتمد على مصدرين اثثين: أحدهما: ما كتب بين يدي رسول الله

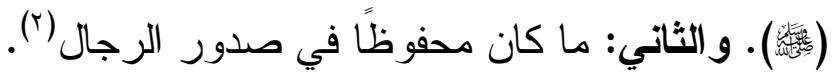

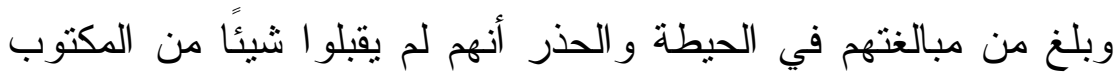

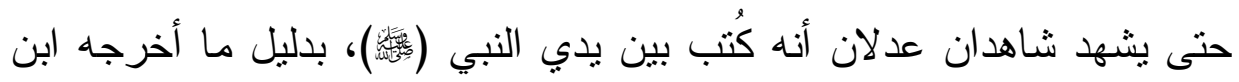

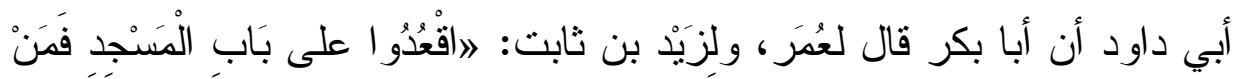

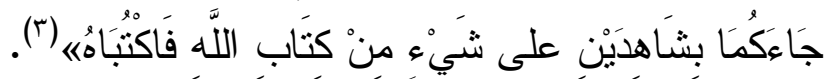
فهذا يدلّ على أن زيدًا كان لا يكتفي لمجرد وجدانه مكتوبًا حتى يشهد بهابه من تلقاه سماعًا مع كون زيد كان يحفظ، فكان يفعل ذلك مبالغة في الاحتياط(؟).

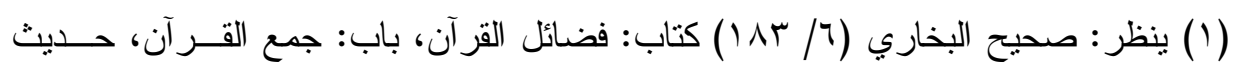

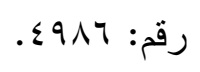

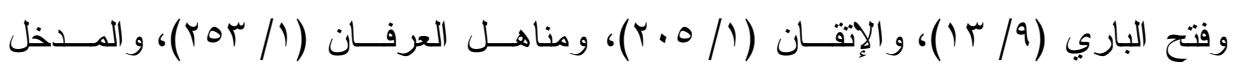
(صV ( ( )

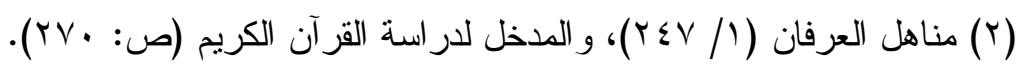

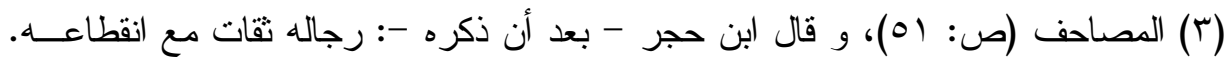

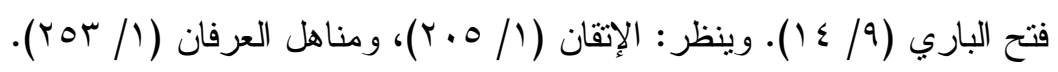

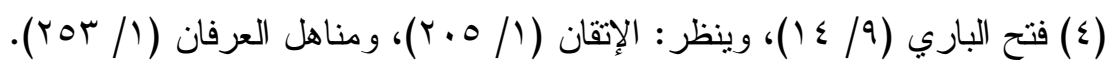


ومعنى الحديث: من جاءكم بشاهدين على شيء من كتاب الله الذي كتب

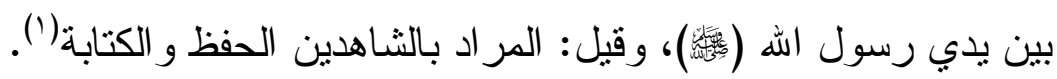

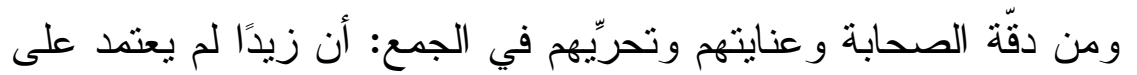
الحفظ وحده، ولذلك قال في الحديث الذي رواه البخاري(r) إنه لم يجد آخر سورة براءة إلا مع أبي خزيمة، أي: لم يجدها مكتوبة إلا مع أبي خزيمة الأنصاري، مع أن زيدًا كان يحفظها، وكان كثير من الصحابة يحفظونها، منهم عمر بن الخطاب، و أبي بن كعب، ولكنه أراد أن يجمع بين الحفظ و الكتابة زيادة في التوثق، ومبالغة في الاحتياط، حتى لا يكتب القرآن إلا من عين ما

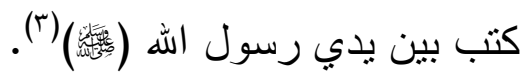
• ومما يُشتار إليه أن زيد بن ثابت لم ينفرد وحده بجمع القرآن، بل شاركه

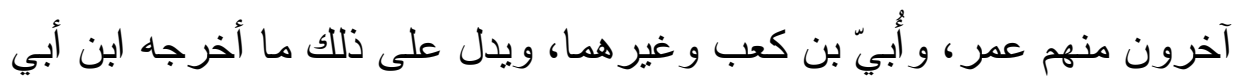

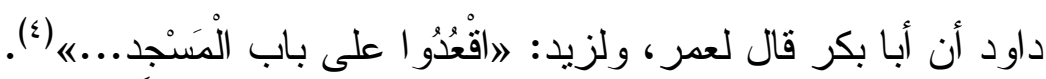
وفي رواية سفيان بن عيينة: الققال أبو بكر: أمّا إذا عزمتَ على هذا فأَرسل إلى زيد بن ثابت فادعه....حتى يجمعْه معناه (0).

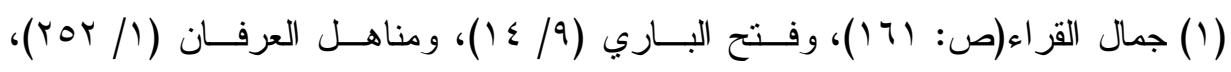

$$
\text { و المدخل (ص: • (YV) }
$$

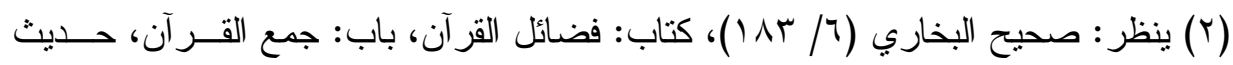

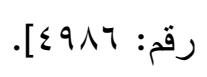

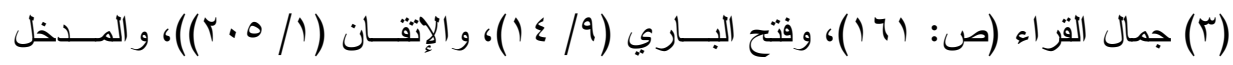

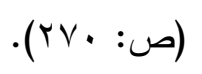

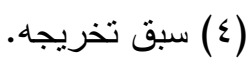

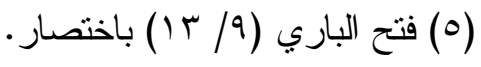


اومن طريق أبي العالية: أنهم لما جمعو ا القرآن في خلافة أبي بكر كان

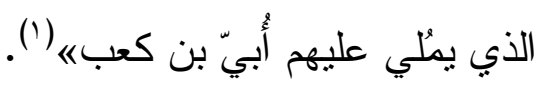

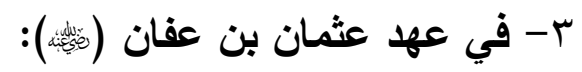

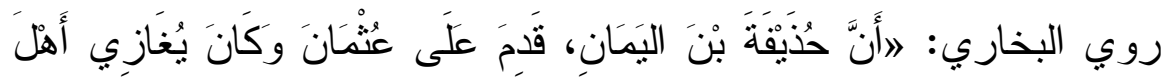

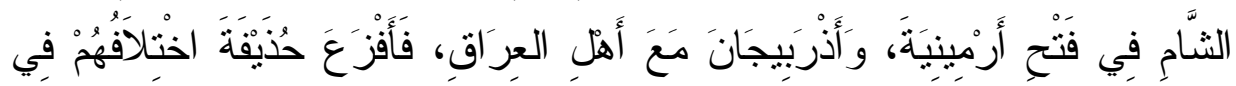

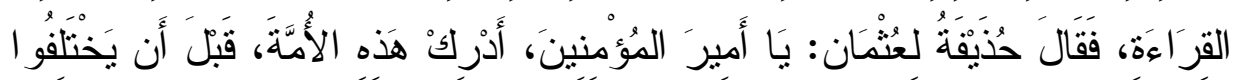

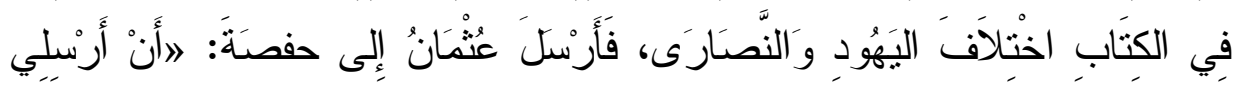

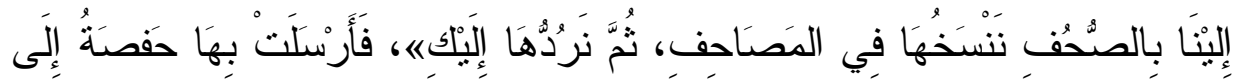

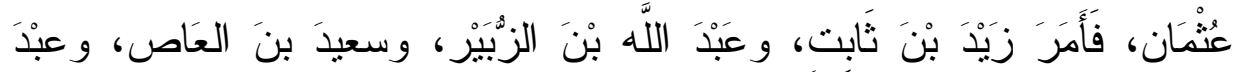

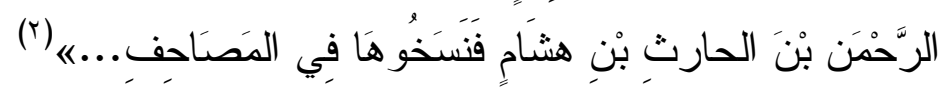

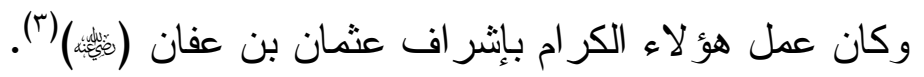

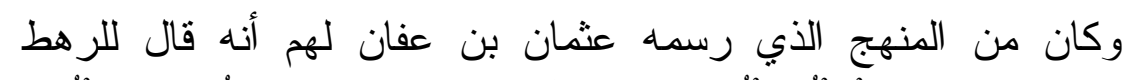

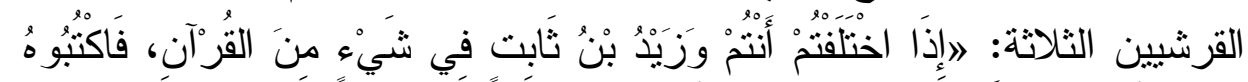

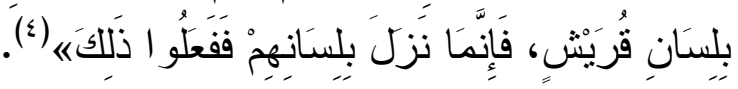

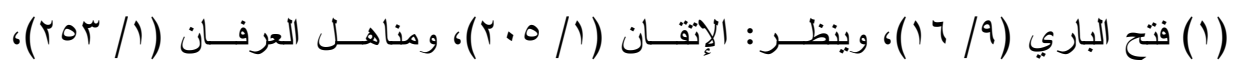

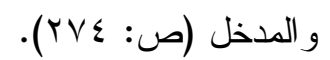

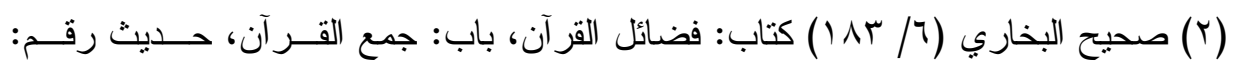

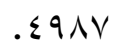

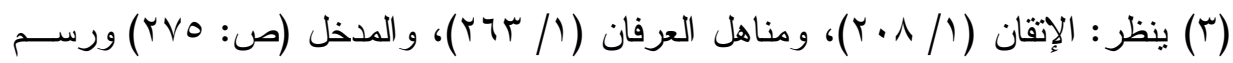

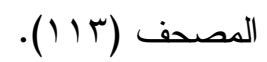
(乏) جزء من حديث البخاري السابق تخريجه. 
وكان هدف عثمان (نبلئن) هو توحيد الأمة وجمعها على حرف و احد، حتى

يقضي على أي شيء يفتح بابًا للفتتة أو الاختلاف ('). و أخذ الكُتّاب من الصحابة في نسخ هذه الصحف بكل دقة وحرص، وكانو ا لا يكتبون في هذه المصاحف إلا ما تحققو ا أنه قر آن، و علمو أنه قد استقرَّ في

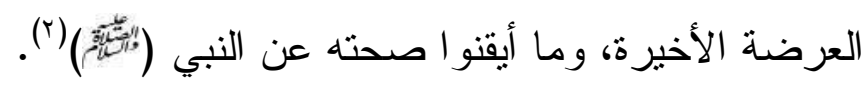
ومن أمتلة الدقة و الضبط والإتقان و التحري اختلافهم في »التابوته قال الزهري: فاختلفو ايومئذ في »التابوت، و التابوه《 فقال القرشيون: التابوت، وقال زيد: التابوه، فرفع اختلافهم إلى عثمان، فقال: 》اكتبوه التابوت؛ فإنه نزل بلسان

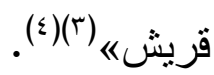

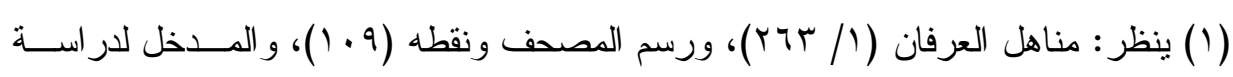
القرآن (ص: (Y) (Y) (Y)

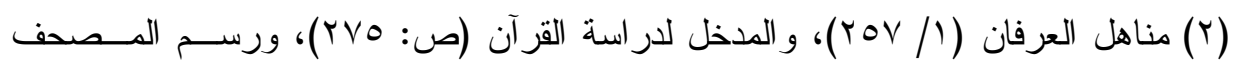

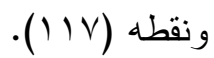

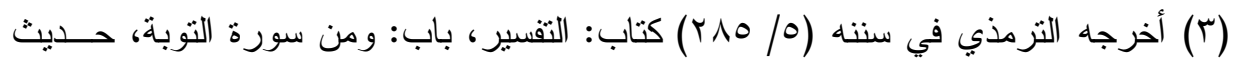

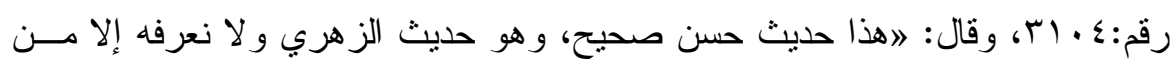

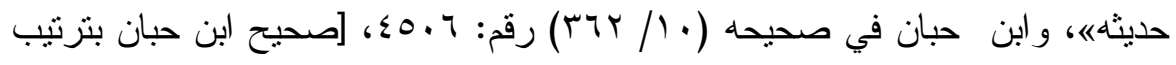

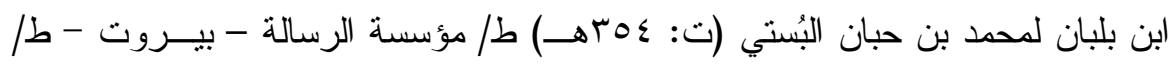

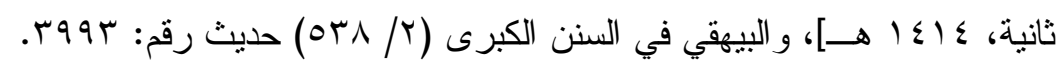

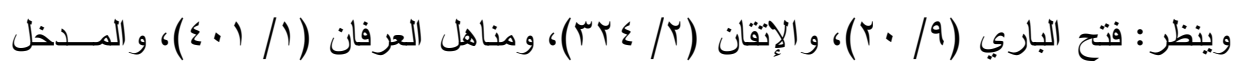

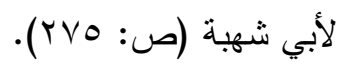

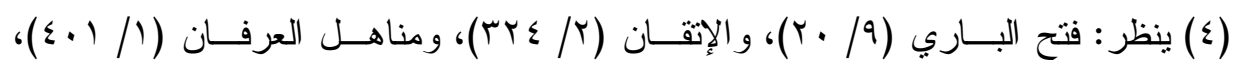

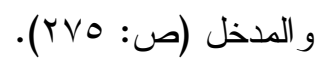




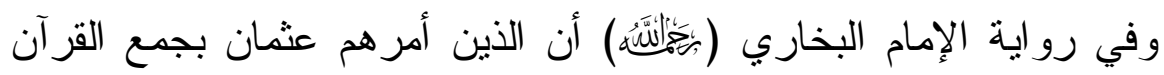

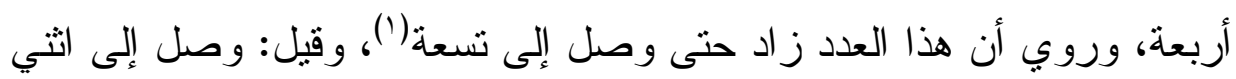

عشر رجلاً من قريش و الأنصار (r). ولا تعارض بين هذه الروايات، يقول ابن حجر: وكأنَّ ابتداء الأمر كان

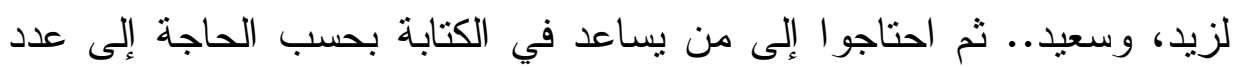
المصاحف التي ترسل إلى الآفاق فأضافو ا إليهم (广).

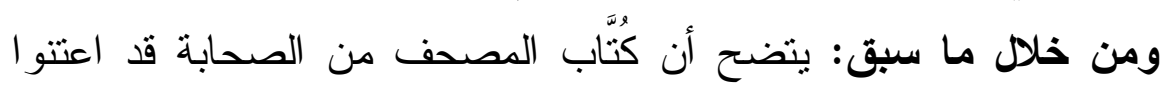

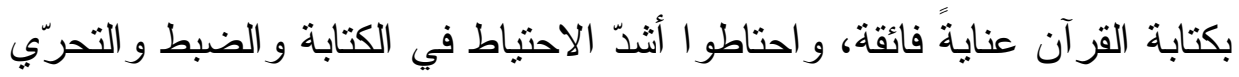

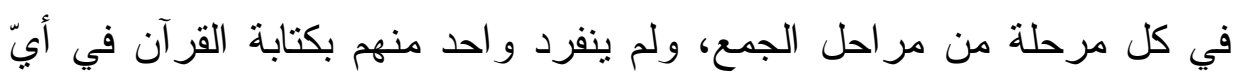

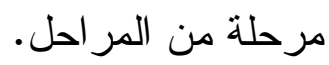

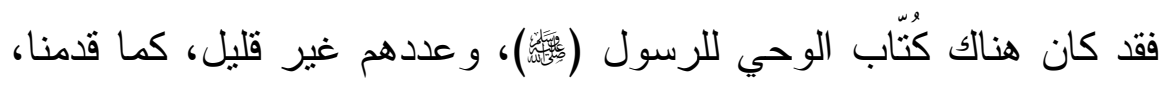

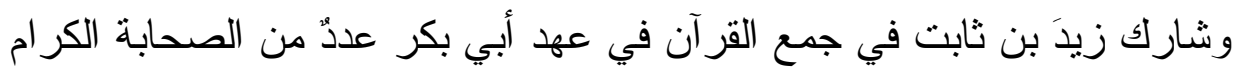

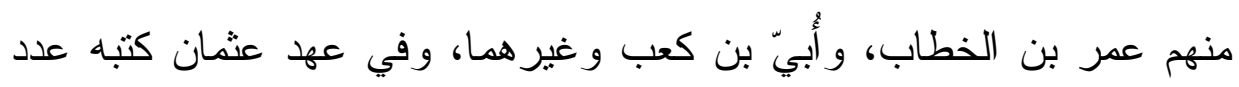

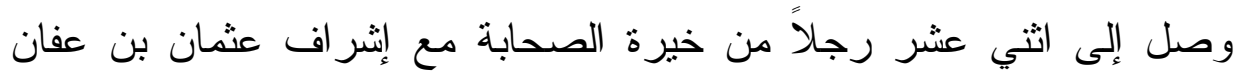

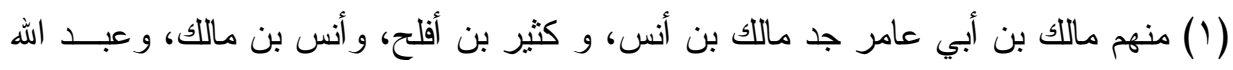

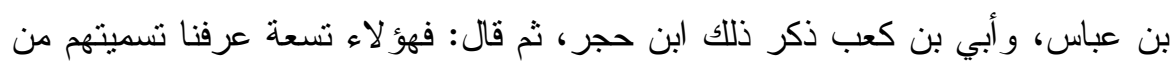
الاثثى عشر . فتح الباري (19/ (19).

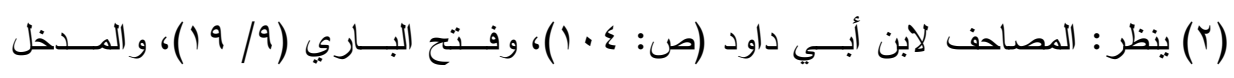

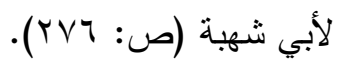

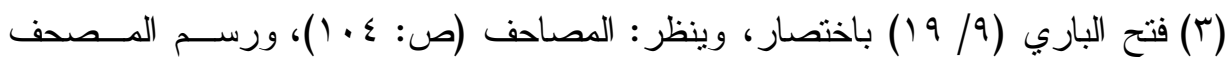

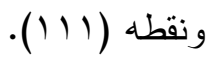




\section{الهبحث الثانيب \\ ما ورد هول همأ الكاتب في تبديل كهمات وحروف}

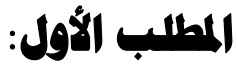 \\ ما ورد في تبديل كلمات بكلمة}

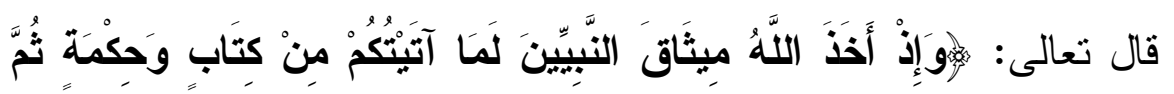

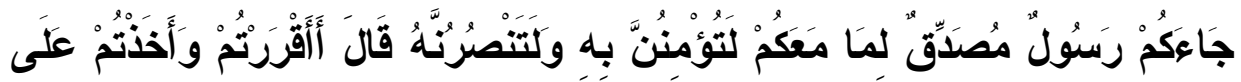

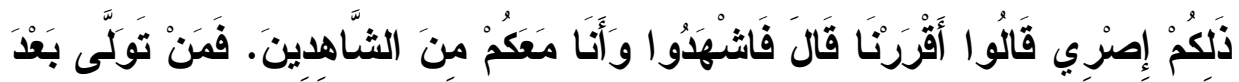

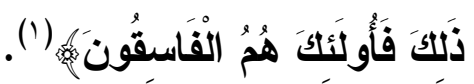

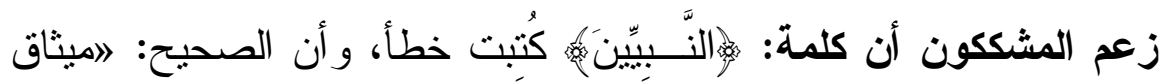
الذين أُوتوا الكتابه و استدلو ا على هذا الزعم بما أخرجه الطبري من طريق

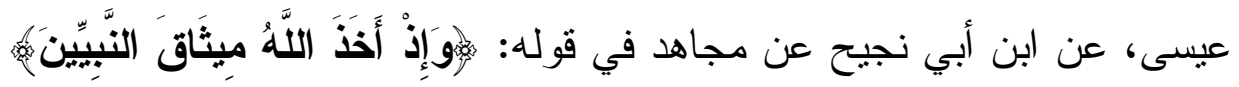

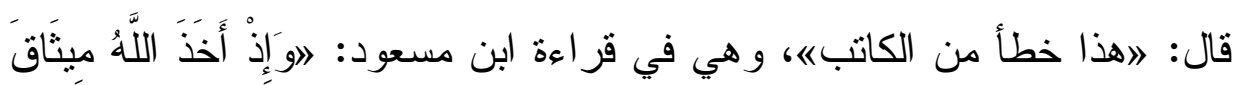

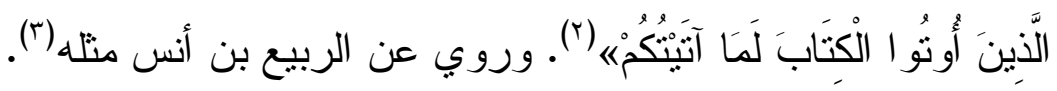

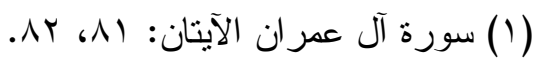

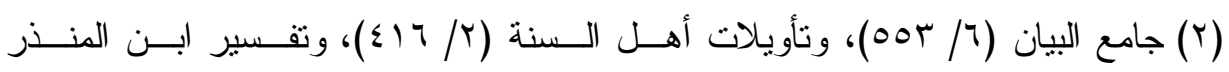

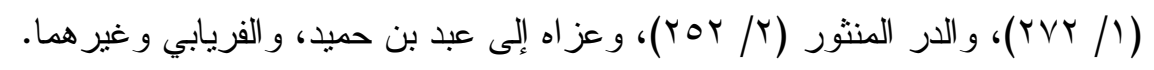

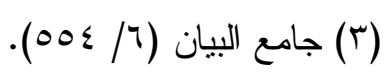




\section{دراسة الزتعم والمكم عليه}

\section{أولًاً: الد|فع للهذ|الزعم:}

لعلَّ ما دفع مجاهدًا، أو الربيع - إن صحَّ عنهما - أو دفع من وضعه عليهما أن يقول: 》هذا خطأ من الكاتبه ما يأتي:

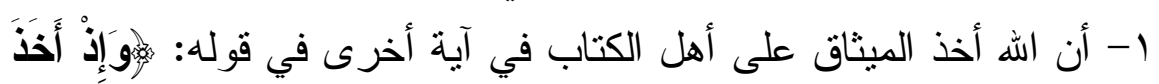

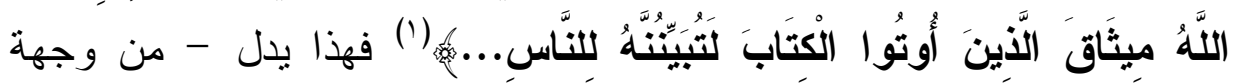
نظرهم - على الخطأ في الكتابة، وأن المخاطبين هم أهل الكتاب، قال مجاهد

و الربيع: إنما أخذ ميثاق أهل الكتاب، لا ميثاق النبيين(؟).

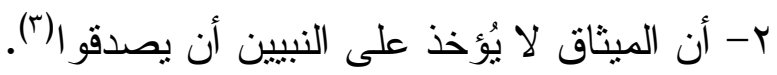

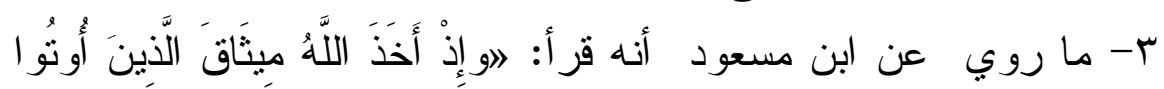
الكتاب

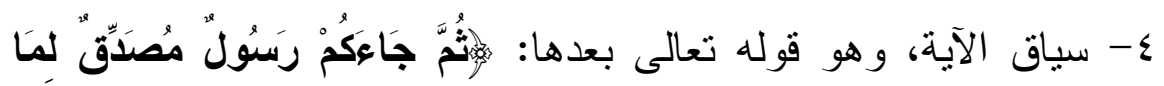

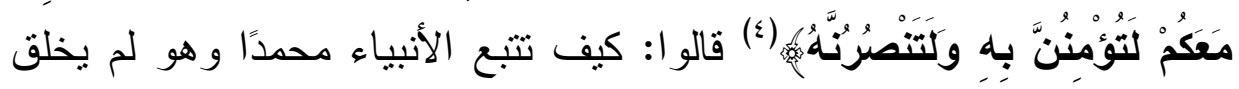
بعد، وكيف ينصرونه وهم غير موجودين وقت بعثته؟!ومن ثمّ فالمر اد أهل

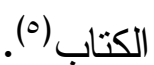

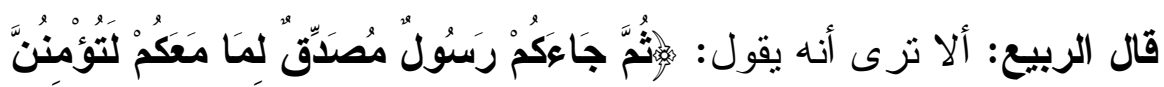

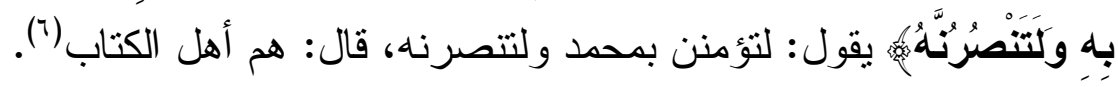

$$
\begin{aligned}
& \text { (1) سورة آل عمران من الآية: INV. }
\end{aligned}
$$

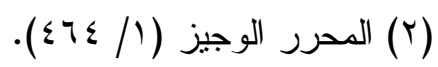

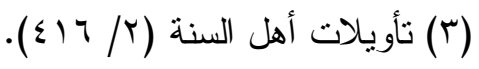

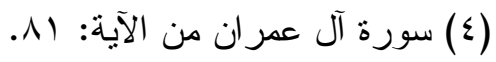

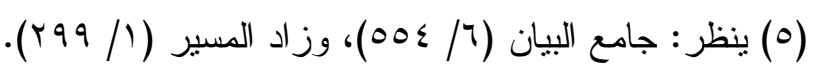

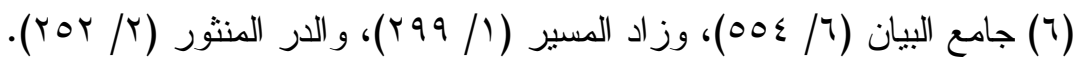




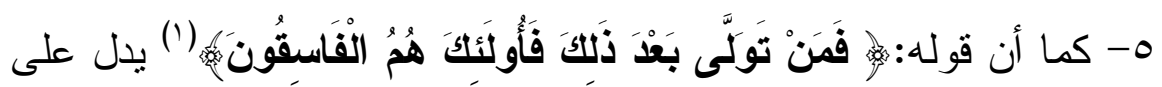

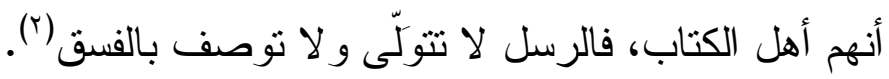
وفي بيان هذه الحجة قال الطبري: قالوا: إنما أخذ الله بذلك ميثاق أهل ألهل

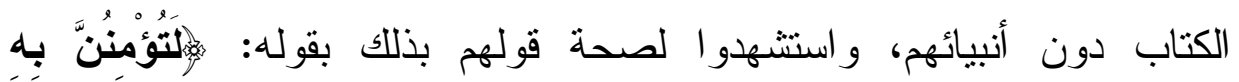

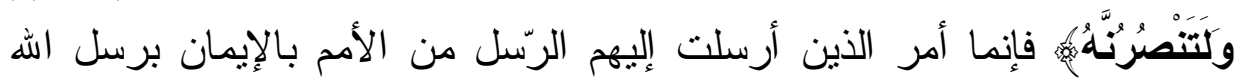

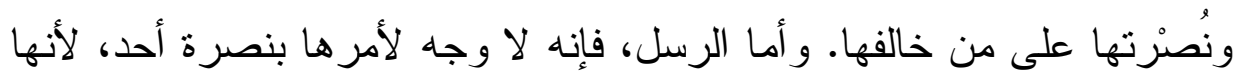

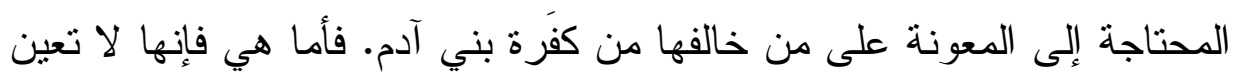

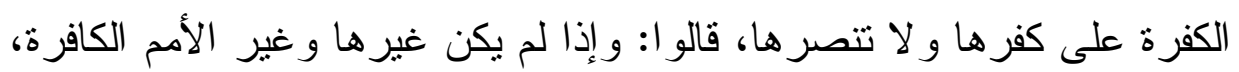

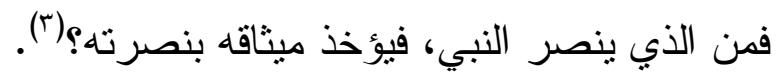

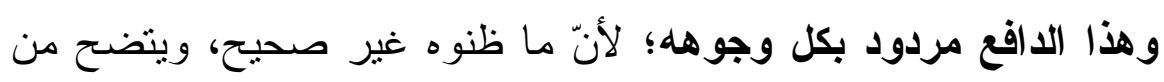

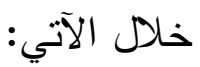

1- أن الميثاق كما أُخذ على أهل الكتاب أُخذ على النبيين، وعلى بني آدم.

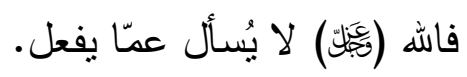

r- وأما الزعم أن الميثاق لا يُؤخذ على على النبيين أن يصدقوا(و)، فهذا

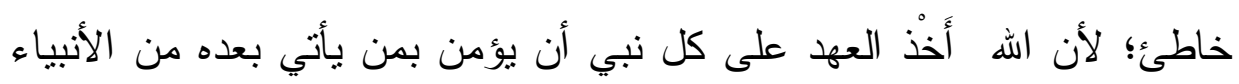

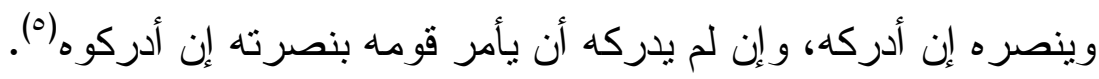

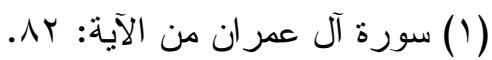

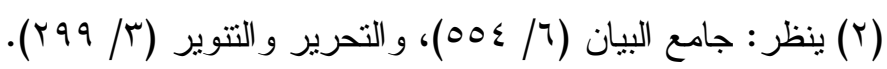

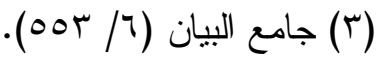

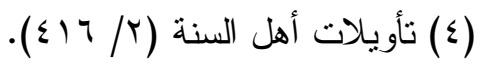

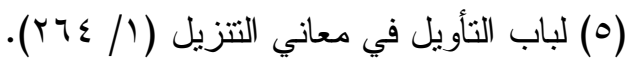




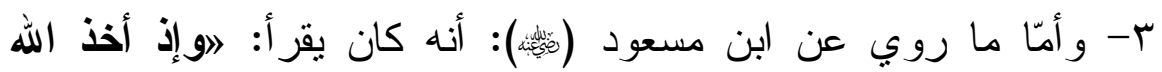
ميثاق الذين أوتوا الكتاب لما آتيتكمه فهذا غير صحيح، لأن الثابت عنه والذي لئي

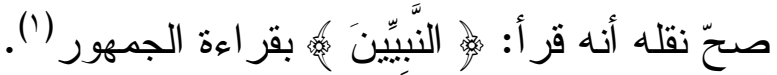

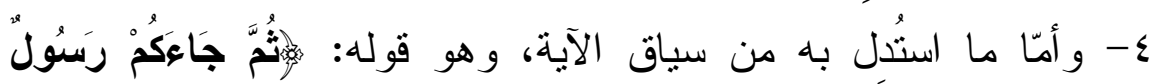

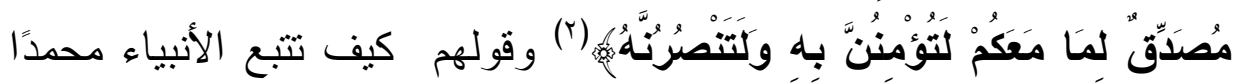
وهو لم يخلق بعد، وكيف ينصرونه وهم غير موجودين وقت بعثته - فهو

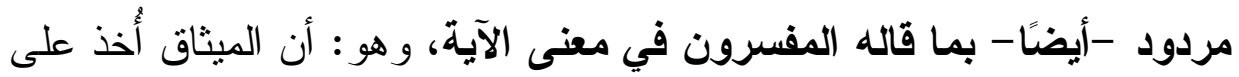
الأنبياء؛ لأن الأنبياء قد أمر بعضنها بتصديق بعض، وفي هذا يقول الطبري:

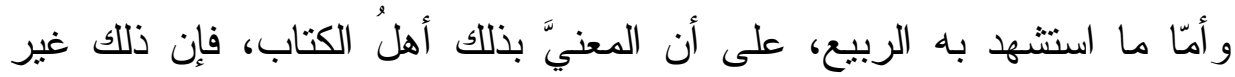

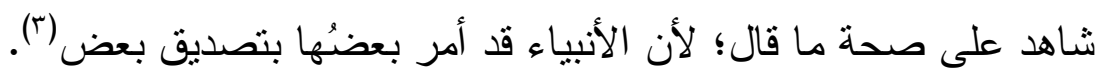

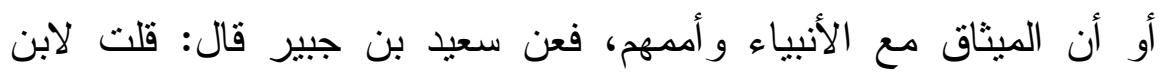
عباس: إن أصحاب عبد الله يقرؤون: 》ميثاق الذين أوتوا الكتابه ونحن

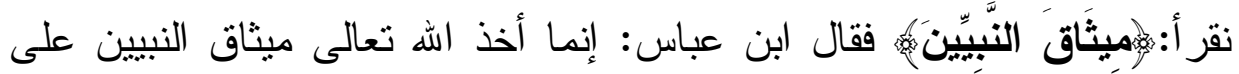

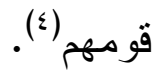

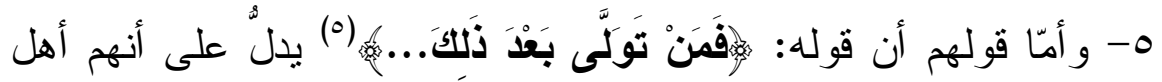
الكتاب؛ لأن الرسل لا تتولّى - فيردّ عليه بما سبق، وهو: أن المقصود أمم

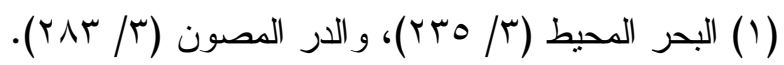

$$
\begin{aligned}
& \text { (r) سورة آل عمران من الآية: الآلم. }
\end{aligned}
$$

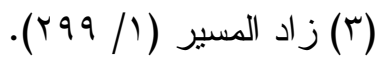

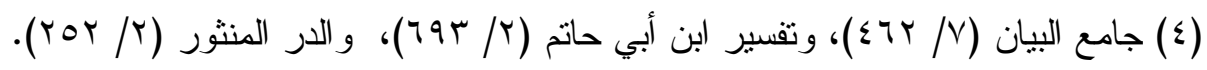

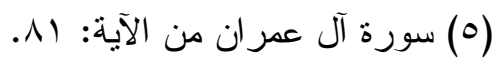


الأنبياء و أتباعهم بعدما أرسل لهم الرسل، وبلغوهم رسالة الهُ('). وسيأتي مزيد لذلك في در اسة الزعم.

\section{ثانيًا: الحكم على الرواية من جهة الإسناد:}

• أما أثز مجاهد، فأخرجه الطبري من طريق عيسى، وهو عيسى بن أبي

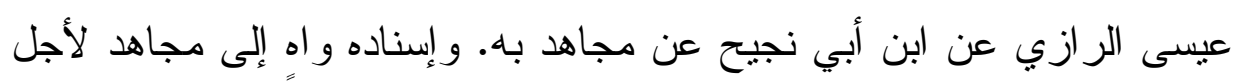
عيسى هذا(r).

قال ابن حجر في عيسى بن أبي عيسى الرازي: صدوق سيء الحفظ(). وقال عبد الله بن أحمد عن أبيه: ليس بقوي في الحديث، وقال العجلي: ليس بالقويّ، وقال عمرو بن علي: فيه ضعف، وهو من أهل الصدق سيّء الحفظ، وقال أبو زرعة: شيخ يهم كثيرًا(ُ). وقال شمس الدين الذهبي: ضعيف (0).

• وأمّا أثر الربيع: فقد أخرجه الطبري من طريق عبد الله بن أبي جعفر عن أبيه عن الربيع به، وأبو جعفر هو الرازي، واسمه عيسى بن أبي عيسى، و هو المتقدم في إسناد مجاهد، وعنه: ابنه عبد الله وهو و اه، فهذا لا يصح عi)

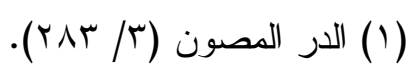

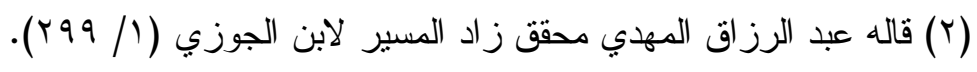

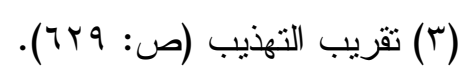

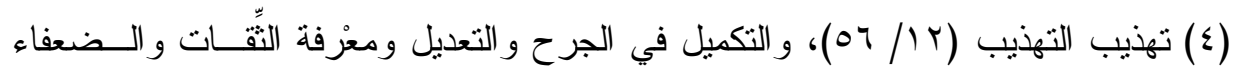

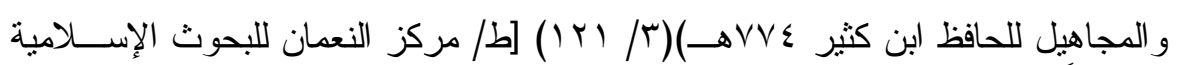

$$
\begin{aligned}
& \text { اليمن -ط/أولى، بrع ا هـ] } \\
& \text { (0) ديوان الضعفاء (ص: rابك) . }
\end{aligned}
$$

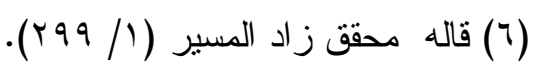


قال ابن حجر: قال محمد بن حميد: عبد الله بن أبي جعفر كان فاسقًا

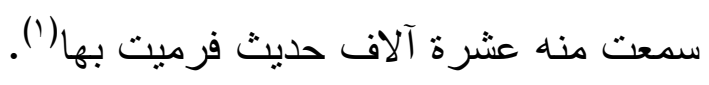

وعلى فرض صحة الإسناد إلى مجاهد أو الربيع:

• فهو قول تابعي، وقول التابعي ليس حجَّة خاصة في منّل هذه المسائل (r). • كما أن هذه الر اوية لا نقوى على معارضة الثابت المنقول بالتو اتر .

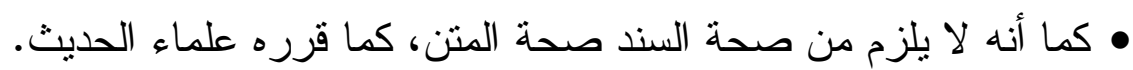
• وهناك من أولَّل قول مجاهد فقال: إنما عنى به أن قر اعة ابن مسعود هي القراءة التي كانت في العرضة الأخيرة، وأن الكاتب كتب القر اءة التي كانت قبل العرضة الأخيرة، وأنه كان عليه أن يكتب ما كان في العرضة الأخيرة، فأخطأ وكتب القر اءة الأولى، ولم يرد بقوله: 》خطأ من الكاتبه أنه وضع ذلك من عند نفسه (r)

أقول: وهذه المحاولة لم تخفف شيئًا، فسو اء قصد مجاهد هذا أو ذاك، فروايته -كما وردت- مردودة قطعًا لاشكّّ في ذلك حتى ولو صحّ إسنادها؛ لأنها تطعن في القر آن. قال السمين: وهذا خطأ من قائله كائنًا مَنْ كان، ولا أظنهُه يصح عن

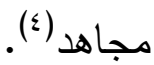

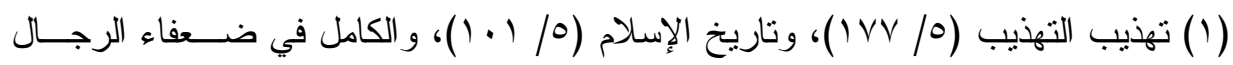
(rT) /0)

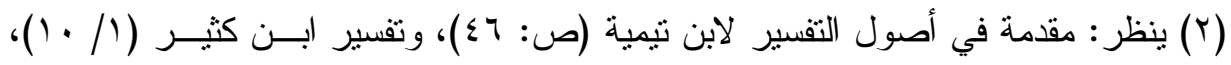

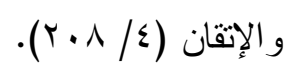

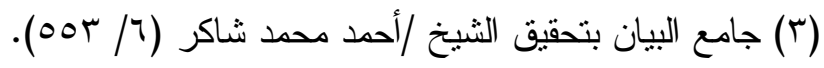

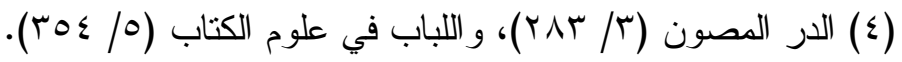


وأمّا ما روي عن ابن مسعود: أنه كان يقر أ: 》ميثاق الأين أوتوا الكتاب《

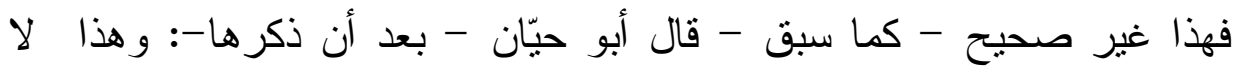

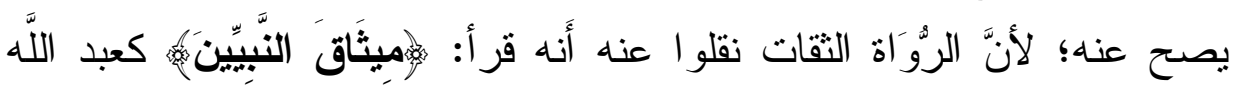
بن كثير و غيره(')

\section{ثالثا: ردّالرواية من جهة المتن:}

• يكفي في رد هذه الرو اية أن متتها شاذ يشتمل على مخالفات، منها: 1- مخالفة إجماع الأمة، ونواتر القرآن، فأيّ رواية تخالف ذلك فباطلة مهما كان قائلها.

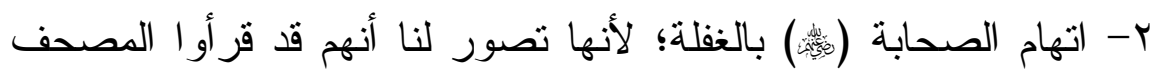

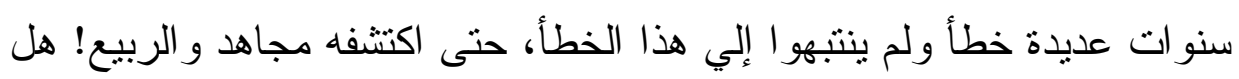
هذا يعقل؟ كيف ذلك وقد كان عدد الصحابة ألوفًا مؤلفة في كل البلاد! وكيف ذلك و هم يومها لا شاغل لهم إلا كتاب الله تعالى؟!

\section{رابعًا: موقفع الهمسرين من هذه الرواية:}

لم تجد هذه الرو اية أي قبول عند المحققين، فالكثير منهم لم يذكرها، وهناك من ذكروها، وبينو ا ضعفها، وفسادها منهم الطبري، وابن عطية، وأبو حيان، و ابن عاشور •

قال ابن عطية: وهذا لفظ مردود بإجماع الصحابة على مصحف عثمان (r). وقال أبو حيان: وهذا لا يصح عنه، و إن صحّ ذلك عن غيره فهو خطأَّ).

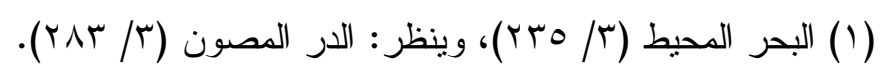

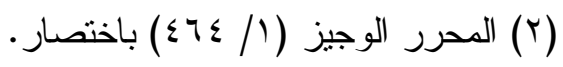

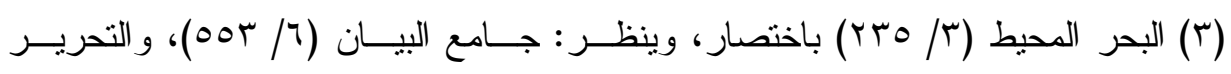

$$
\begin{aligned}
& \text { و التتوير (r/ (r99). }
\end{aligned}
$$


وق علّق المحقق الشيخ أحمد شاكر على هذه الرواية فقال: بمثل هذا

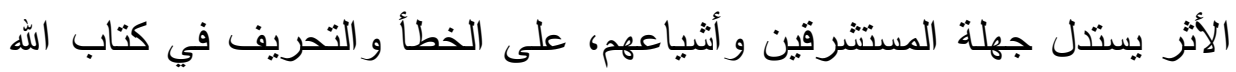
المحفوظ، ولم يقصرّ علماء الإسلام في تعقب آرائهم وبيان فسادها، ووهن ونس

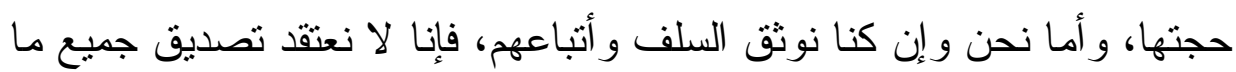
يروى عنهم، بل نعتقد أن فيه كذبًا كثيرًا قد قامت الدلالة على أنه موضوع عليهه.... ومن ثَنَّ لم يجب أن نحفل بشيء من هذه الروايات عنهم (').

\section{خامسًا: در|سة موضع الزعم:}

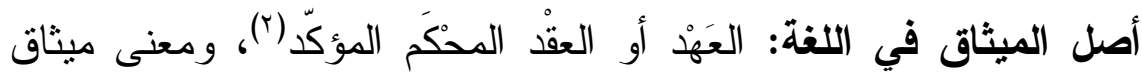
النبـــيّين ما وثقوا به على أنفسهم من طاعة الله فيما أمرهم بـ ونهاهم عندا (r)

\section{واختُّف في المعنى على وجوه:}

أحدها: أنَّ الكلام على ظاهره، و أن الله تعالى أخذ على الأنبياء مو اثيق قبل

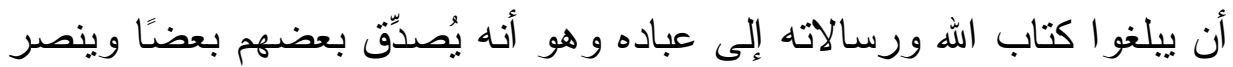

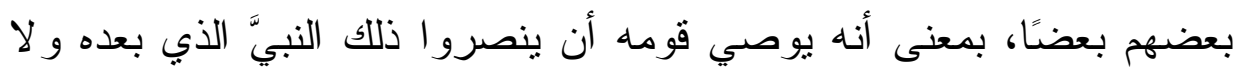

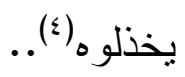

فأخذ العهد على كل نبي أن يؤمن بمن يأني بعده من الأنبياء وينصره إن

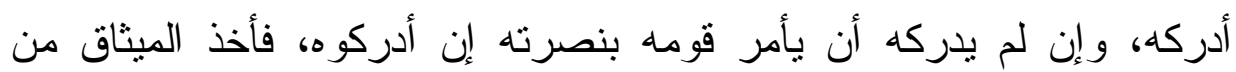
موسى أن يؤمن بعيسى، ومن عيسى أن يؤمن بمحمد -كما سبق -(0).

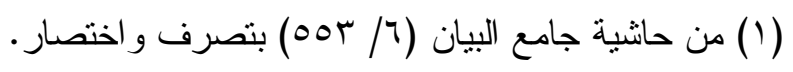

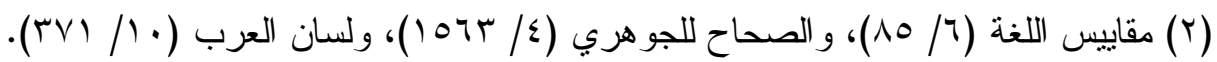

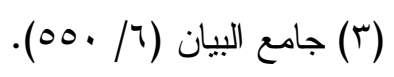

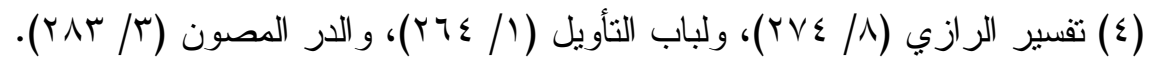

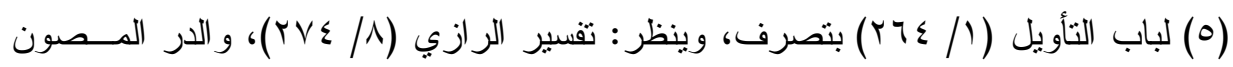
( $($ ( A $/$ / 
الثاني: أن الميثاق مضاف لفاعله و الموثَق عليه غير مذكور لفَهْ المعنى،

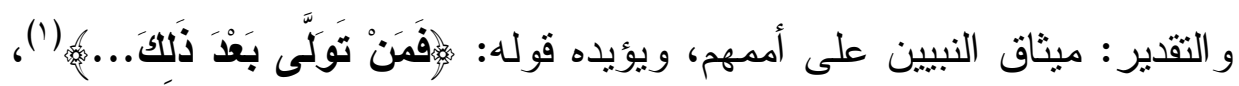

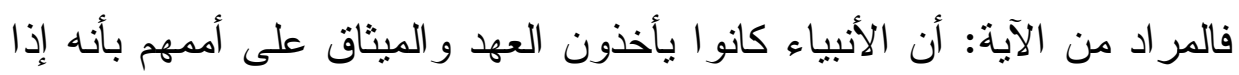

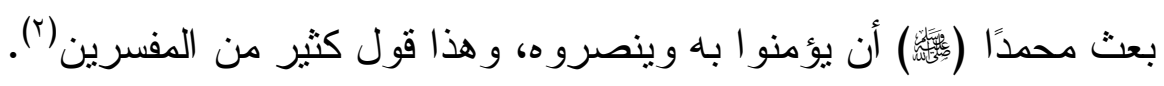
الثالث: أنه على حذف مضاف تقديره: ميثاق أمم الأنبياء، ويؤيده قوله:

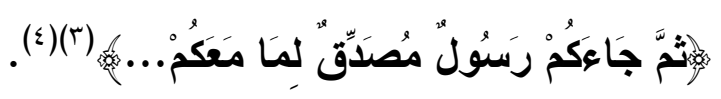

الرابع: قيل: أخذ اله الميثاق على النبيين وأممهم جميعًا في أمر النبي فاكتفى بذكر الأنبياء؛ لأن العهذ مع المتبوع عهد مع الأتباع، وهو قول ابن عباس.

وقال علي بن أبي طالب: ما بعث الله نبيَّا آدم فمن بعده إلا أخذ عليه العهد في أمر محمد، وأخذ هو العهد على قومه ليؤمنن به ولئن بعث وهم أحياء

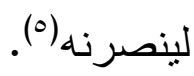

الخامس: قال الزمخثري: أن ير اد أهل الكتاب، وأن يرد على زعمهم

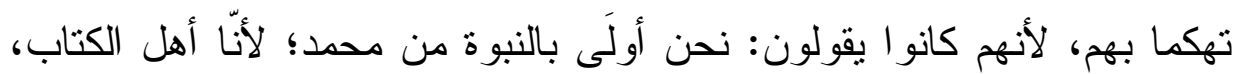

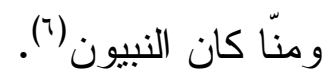

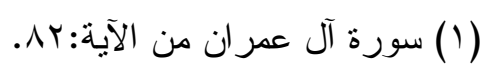

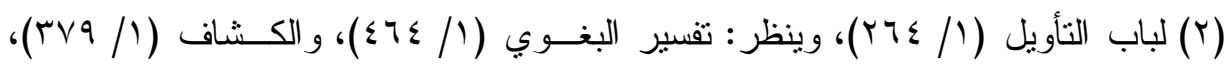

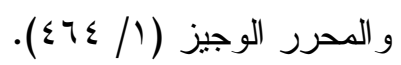

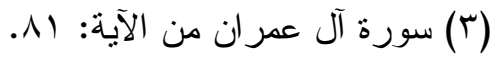

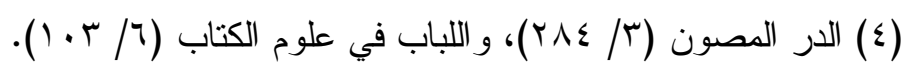

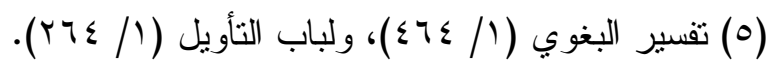

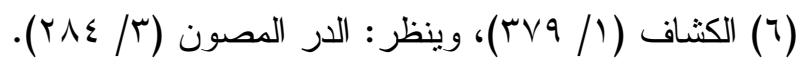


أقول: وهذا الوجه الذي ذكره الزمخشري غريب جدًا، وبعيد عن معنى الآية، وأمّا الأقو ال السابقة عليه فجائزة في معنى الآية.

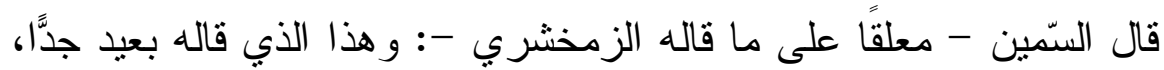

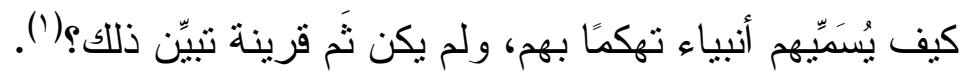

\section{الإلب الثاني}

\section{ما ورد هول خطأ الكاتب في تبديل كلمة بكلمة}

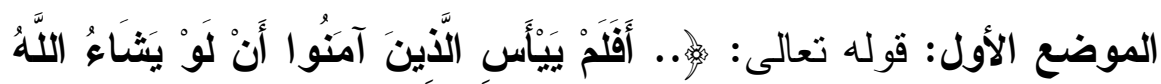

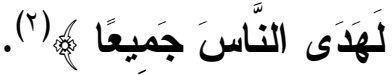

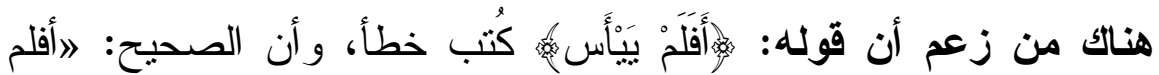
يتنينه(r). وممّا يدل لزعمه: ما أخرجه الطبري قال: حدثتا أحمد بن يوسف انف قال: حدثنا القاسم قال: حدثنا يزيد، عن جرير بن حازم، عن الزبير بن

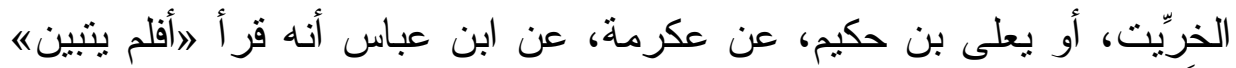

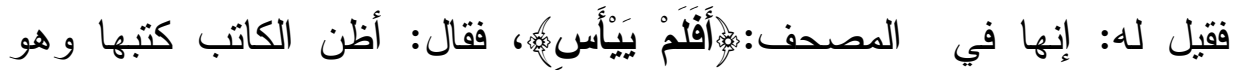
ناعس (£). (1).

$$
\begin{aligned}
& \text { (1) الدر المصون (r/ ع ץ). }
\end{aligned}
$$

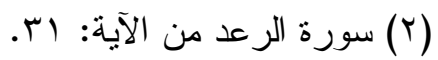

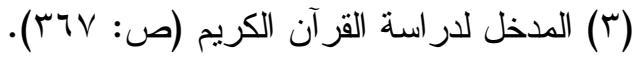

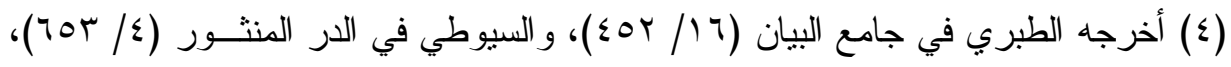

$$
\begin{aligned}
& \text { وعزاه لابن الأنباري. }
\end{aligned}
$$




\section{داسمة الزعم والمكم عليه}

أولاً: الو|فع لهذ|الزعم:

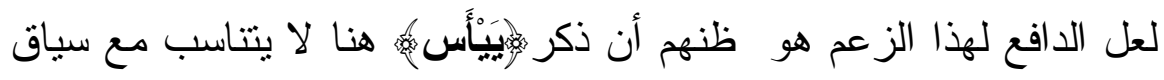

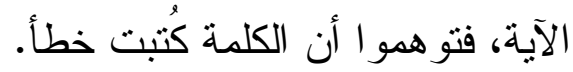

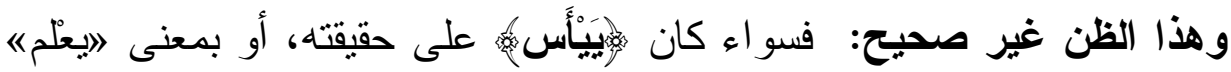

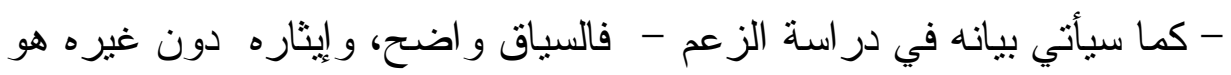

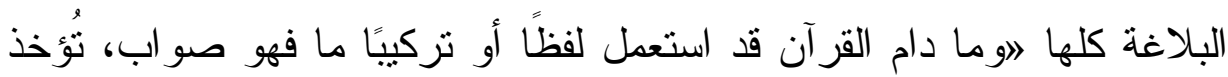

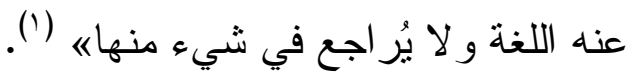

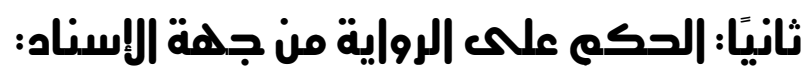

ساق ابن جرير هذا الخبر بإسناد صحيح قال الثيخ /أحمد شاكر : فهذا خبر التهاه

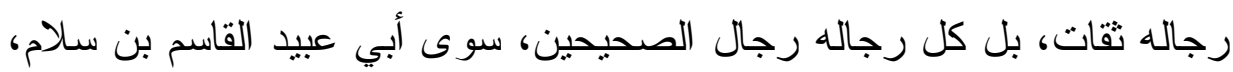
وهو إمام ثقة صدوق، فإسناده صحيح (r) رجال. استدر الك الثيخ شاكر على حكم هذا الإسناد:

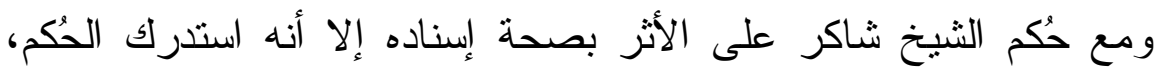

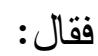

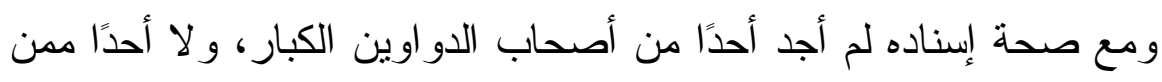

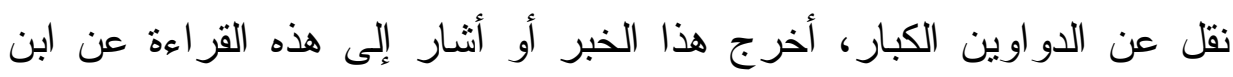

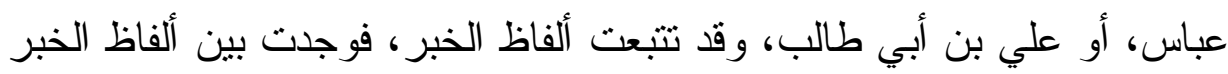

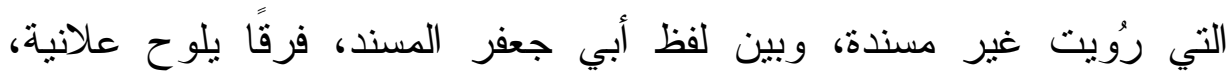

(1) عصمة القرآن الكريم د. إبر اهيم عوض (ص: بr) بنصرف [ط/ مكتبة زهراء الشرق

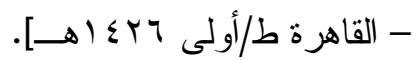

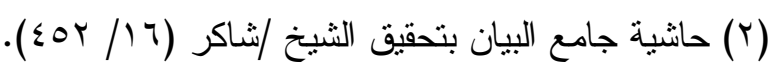


و ألفاظهم هذه هي التي دعت كثيرًا من الأئمة يقولون في قائله بأنه زنديق ملحد!

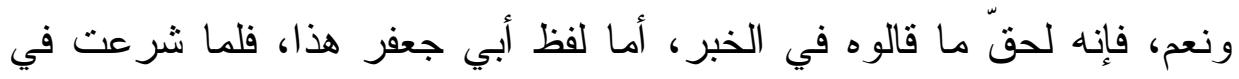
در استه من جميع وجوه الدراسة، انفتح لي باب عظيم من القول في هذا الخبر و أثباهه... و هذا الخبر و أثباهه يتخذه المستترقون وبطانتهم مدرجة للطعن في القرآن، أو تسويلاً للتلبيس على من لا علم عنده بنتزيل القر آن العظيم (').

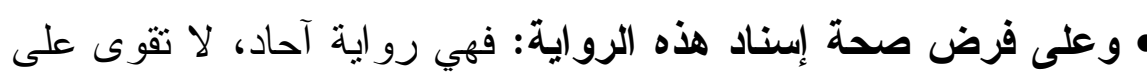

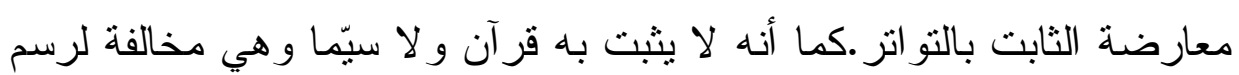

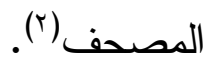

كما أنه لا يلزم من صحة السند صحة المتن كما هو معروف عند المحدثين؛ و لأن الوضيَّاعين وغيرهم كانو اليركبون المتون على الأسانيد الصحيحة حتى يلبسو ا على الناس الحق بالباطل.

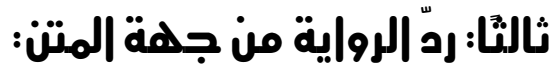

هذه الرو اية مردودة متتاً لما يلي:

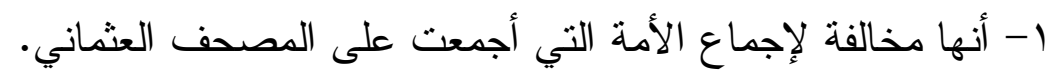

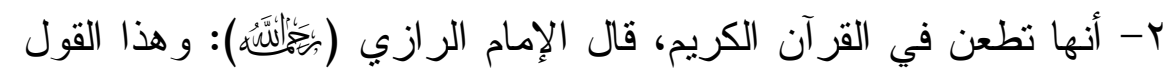

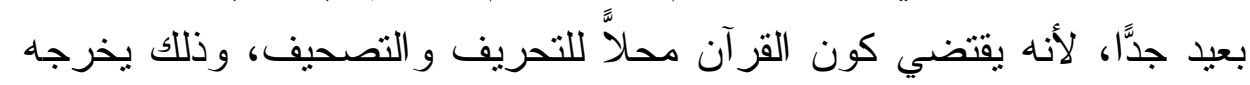

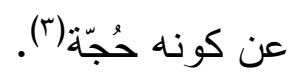
r- تتهم القرآن بوجود الاختلاف فيه، وقد نفى الله وجود الاختلاف في كتابه فقال:

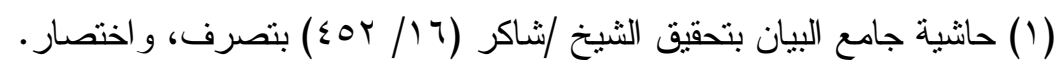

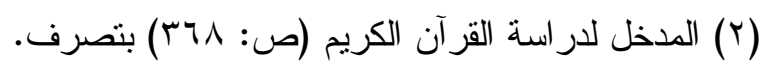

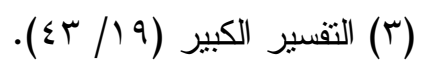

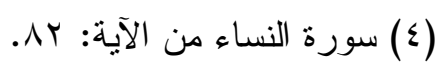


ع- تطعن في الصحابة الكر ام، فإن كان يخفى هذا على من لا يحفظ، فهل يعقل أن يخفى هذا على أولئك الحفظة، حتى يبقى ثابتًا بين دفتي المصحف

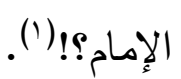
وهل يعقل أن ابن عباس حقَّر من شأن كُتَّب المصحف، وهم المؤتمنون على وحي الله؟ ثم هل يصحّ أن يقول عنه: كتبها الكاتب وهو ناعس، وهم كانو أدق

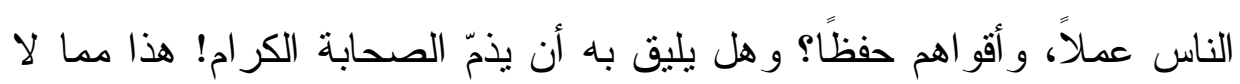
يليق أن يصدر من عوام المسلمين تجاه أحد الصحابة، فكيف بابن عباس حبر

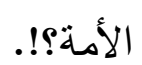

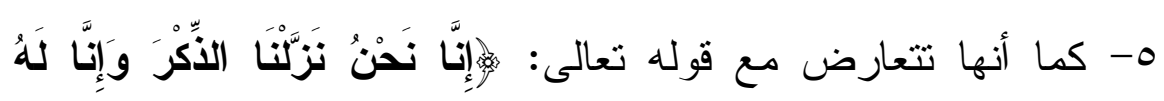

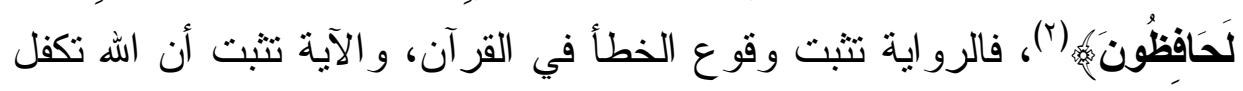
بحفظه.

ج- أن القر اعة الصحيحة المتواترة صحت عن ابن عباس، فلو كان ما

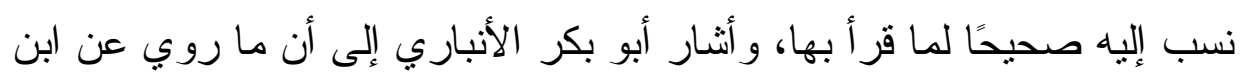

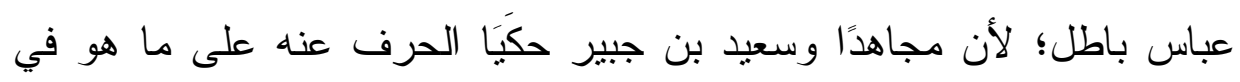

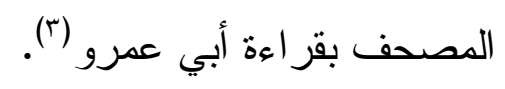
V- و أيضًا لقد أخذ ابن عباس القرآن عن زيد بن ثابت فيمن أخذ عنهم، فغير معقول أن يقر أ ابن عباس على خلاف قر اءة زيد بن ثابت. روي أن نافع

(1) ينظر : الروايات التفسيرية في فتح الباري د/عبد المجيد الثيخ عبد البـاري (ץ/ ؟ ـ ؟)

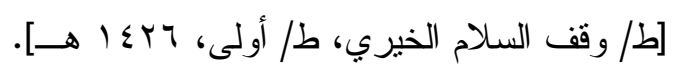

$$
\begin{aligned}
& \text { (Y) سورة الحجر، الآية: } 9 .
\end{aligned}
$$

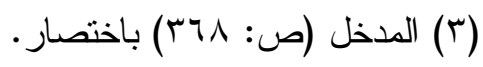


بن الأزرق سأل ابن عباس عن قوله: يعلمه بلغة بني مالك، قال - أي نافع-: وهل تعرف العرب ذللك قال: نعم أما

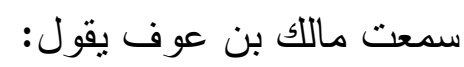

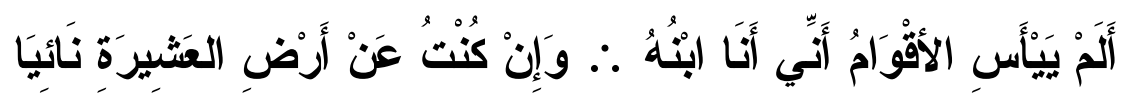
فلو كانت ثابتة- كما افترى عليه- لما فسَّرها، ولبين للسائل أنها خطأ، ولما استشهد لها بكلام العرب(').

\section{رابعًا: موقفع المفسرين من هذه الرواية:}

لم يتساهل كثير من المحققين في إير اد هذه الرواية، بل تعقبوها بالنكير

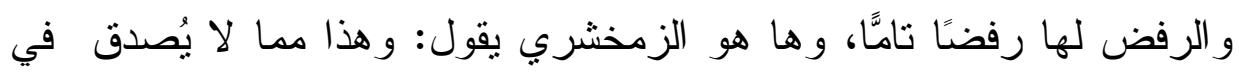
كتاب الله الذي لا يأتيه الباطل من بين يديه و لا من خلفه، وكيف يخفى مثل هذا

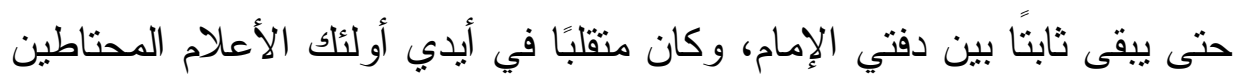
في دين الله المهيمنين عليه لا يغفلون عن جالائله ودقائقه، خصوصًا عن القانون الذي إليه المرجع، والقاعدة التي عليها البناء، هذه و الله فرية ما فيها مرية(؟). ووصف أبو حيّان قائلها بأنه زئه زنديق مُّحد (r). وقال الآلوسيّ - بعد أن ذكر كلام أبي حيان-: وعليه فرواية ذلك عن

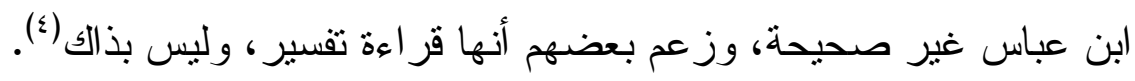

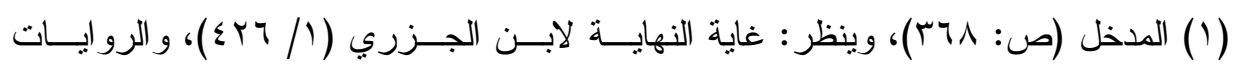

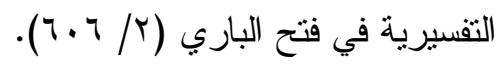

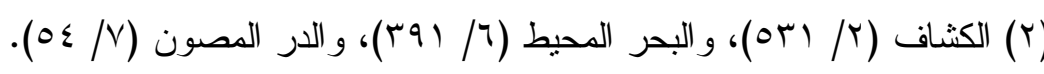

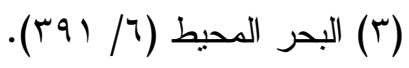

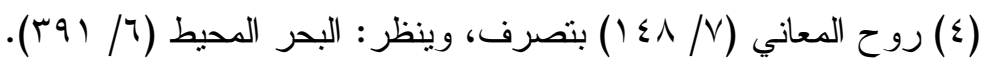


وقال السمين الحلبيّ (بنمّأنسَّة): وقد افترى مَنْ قال: إنما كتبه الكاتب وهو

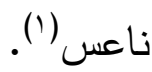

\section{خامسًا: مر|سة موضع الزعم:}

للمفسرين في معنى قوله:

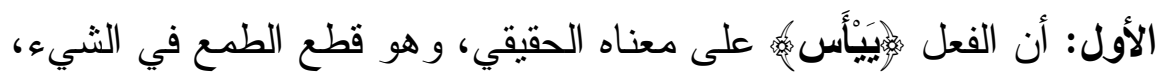

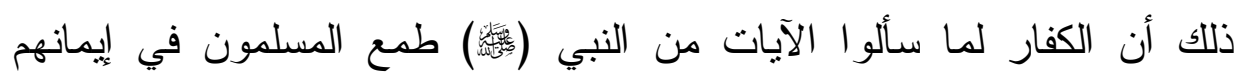
وطلبو انزول هذه الآيات ليؤمن الكفار ، وعلم اله أنهم لا يؤمنون فقال: أفلم ييئس الذين آمنوا من إيمان كفار قريش، ويعلموا أن اله تعالى لو يشاء هداية

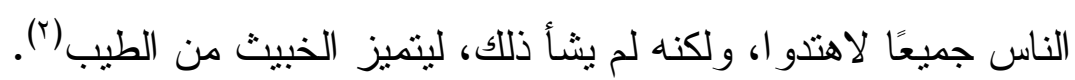

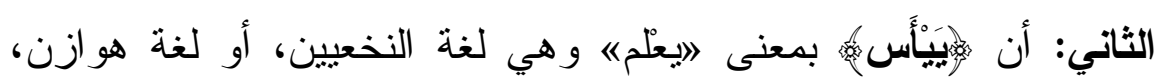
ومما يُستشهد به لهذا الاتجاه قول الثشاعر:

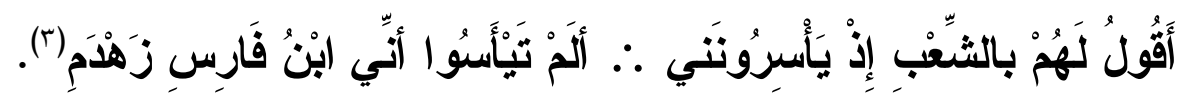
أي: ألم تعلمو ا؟ ومعنى الآية على هذا: أفلم بعلم المؤمنون أنه سبحانه لو شاء هداية الناس جميعا لآمنو |(ई).

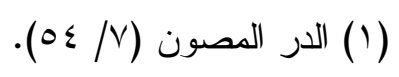

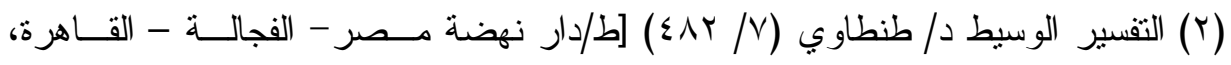

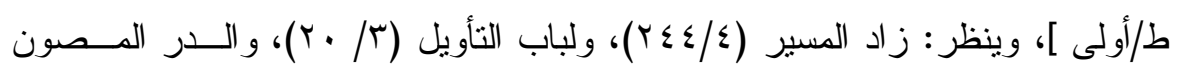

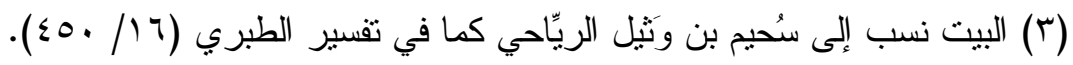

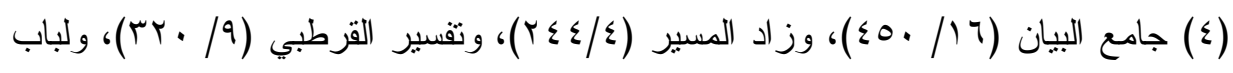

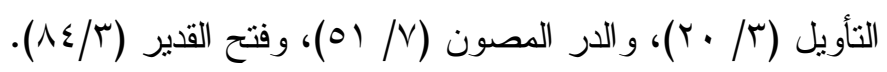


و استُعمل اليأس في معنى العلم لتضمنه له، وهو مجاز؛ لأن اليائس من

$$
\text { الثيء عالم بأنه لا يكون ('). }
$$

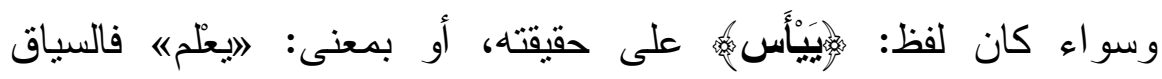

و اضح، و المعنيان جائز ان.

\section{الهوضع الثاني:}

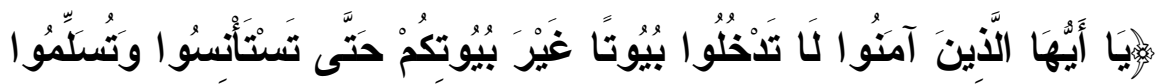

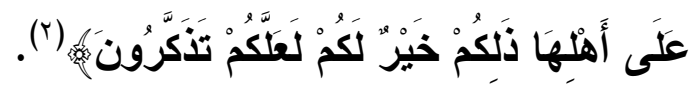

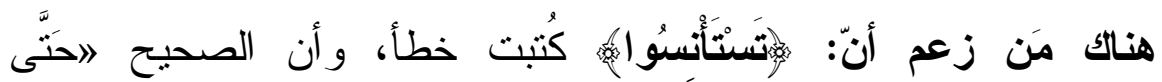

تََتنَأْنواه ومما يدل على هذا الزعم ما أخرجه الطبري قال : حدثنا ابن بشار ، قال: حدثنا محمد بن جعفر، قال: حدثنا شعبة، عن أبي بشر، عن سعيد

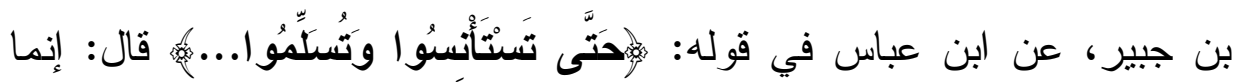

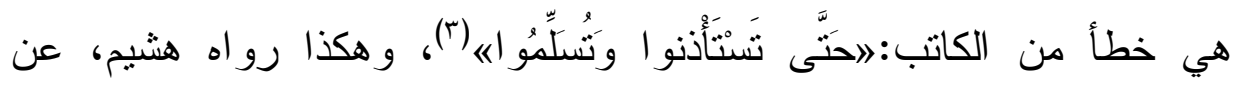

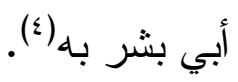

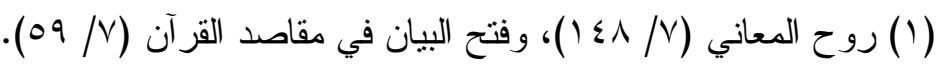
(r) سورة النور الآية: (r)

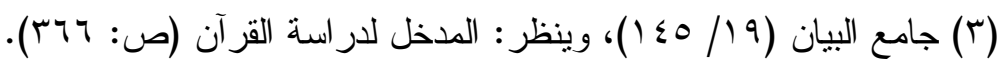

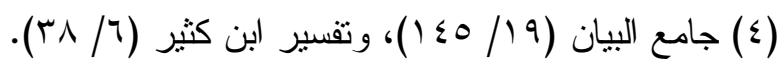




\section{دراسة الزوعم والمكم عليه}

\section{أولاً: الد|فع لهذ|الزعم:}

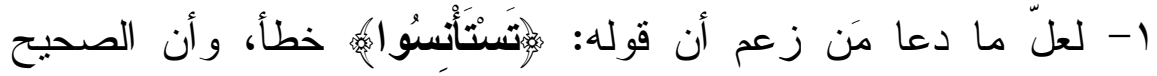

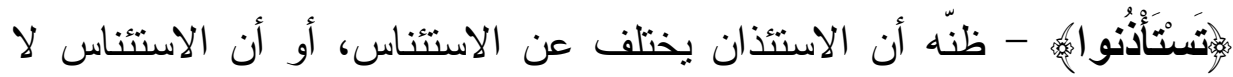

يناسب السياق، أو ظنّه أن الاستئناس يأتي بعد الاستئذان (').

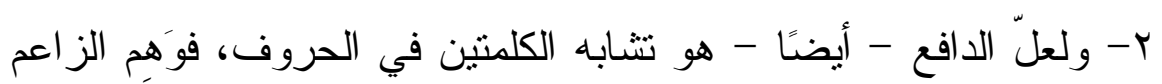

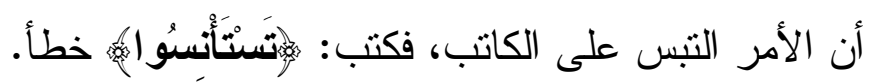

\section{وهذا الظن غير صحيح، لما يلي:}

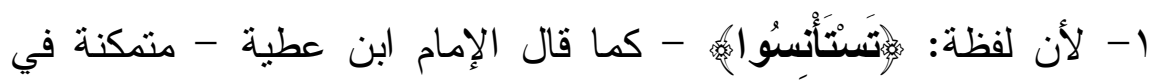

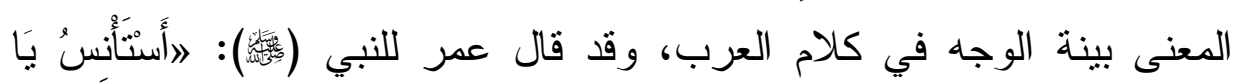

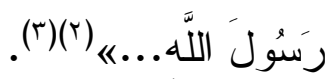

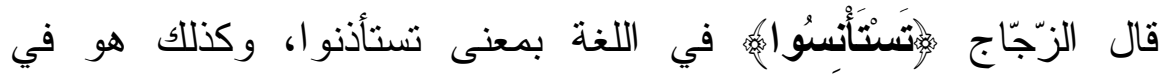

التفسير (£).

• و إن كان الظنّ أن الاستئناس يأني بعد الاستئذان وبعد الرؤية فهذا خاطئ

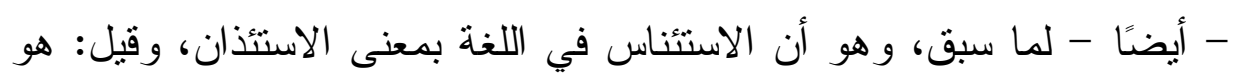

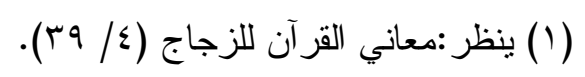

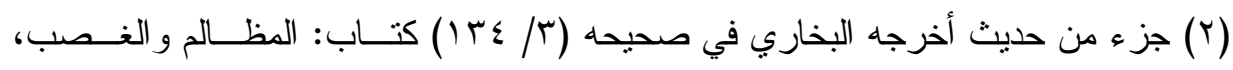

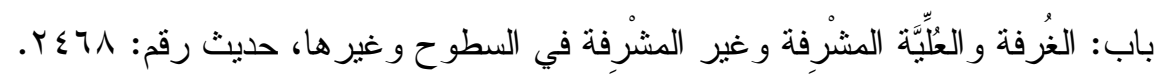

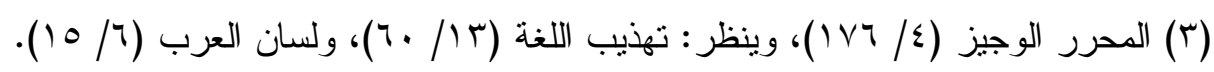

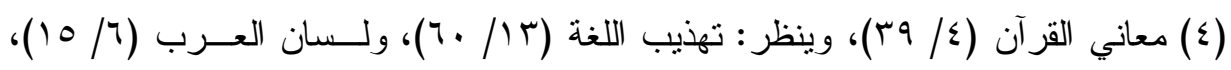

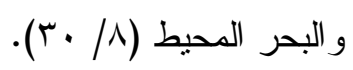


بمعنى تستعلمو ا، أي تستعلمو ا من في البيت. وصفة الاستعلام أن تقول: السلام عليكم، أٔدخل؛ أو بالتتحنح، أو بأي وجها أمكن ('). قال القاضي ابن العربي: فلا مانع في أن يعبّر عن الاستئذان بالاستئناس،

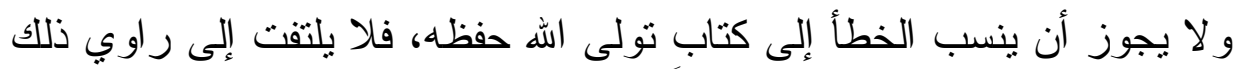

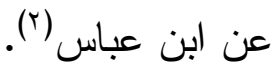

ץ- وإن كان الدافع لهم تشابه الكلمنين في الحروف، وأن الكاتب التبس

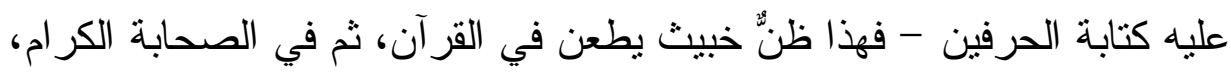
و هو مخالف للحقيقة و الواقع، ومناف تمامًا لما كان عليه الصحابة من الدقة و الحرص عند كتابتهم للقرآن - كما سبق بيانه - ثم لماذا اختلط عليهم هذا اللفظ، ولم يختلط عليهج عثر ات الألفاظ المتشابهة في القرآن؟!

\section{ثانيًا: الحكم على الرواية من جهة الإسناد:}

هذا الأثر ضعيف الإسناد: قال الحافظ ابن كثير - بعد أن ذكره -: وهذا

غريب جدًا عن ابن عباس (r).

وقال البيهقي - بعد أن ذكره - : وهذا الذي رو اه شعبة، و اختلف عليه في

إسناده، ورو اه أبو بشر و اختلف عليه في إسناده من أخبار الآحاد (\&).

وقال أبو شهبة: وقد روى هذا الخبر عن ابن عباس ابن جرير، و ولا يخلو

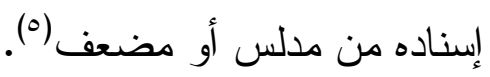

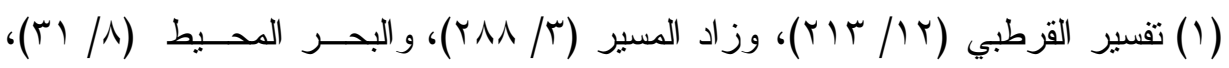

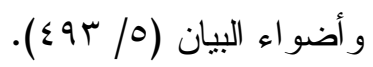

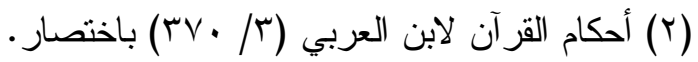

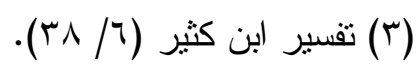

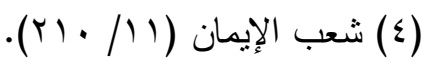

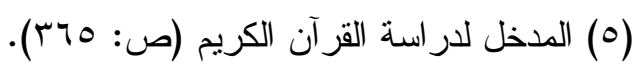




\section{تصميح الماكم لإسناد هذه الرواية:}

صحَّح الحاكم إسناد هذه الرواية في المستدرك(')، وتصحيحه هذا ليس دليلاً

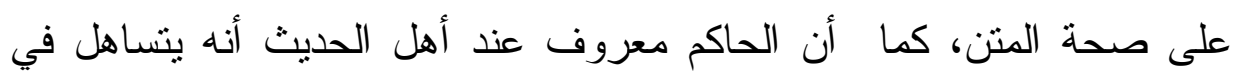

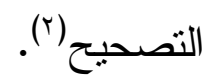

بل هناك من قال: تصحيح الحاكم غير معتبر عند أئمة الحديث(").

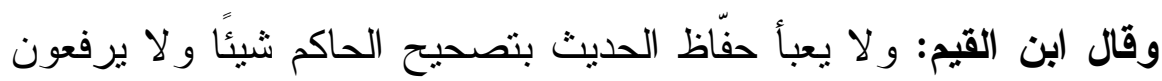

به ر أسًا البتَّة فهو يصحح أثنياء موضو عة بلا شكّ عند أهل العلم بالحديث (؛).

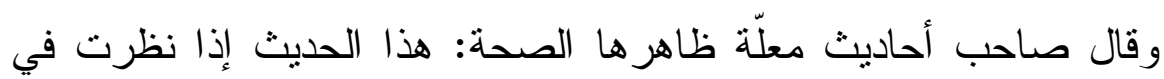

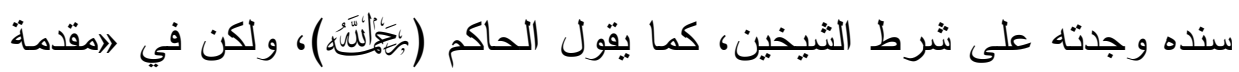
الفتحه أن الثيخين لم يخرجا لجعفر عن مجاهد شيئًا(ه). وعلى فرض صحة الإسناد: فإنه لا يلزم من صحة الإسناد صحة المتن

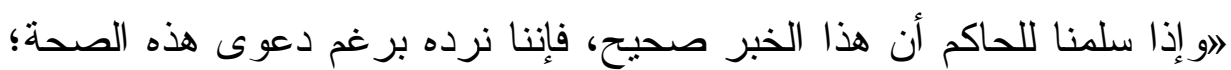

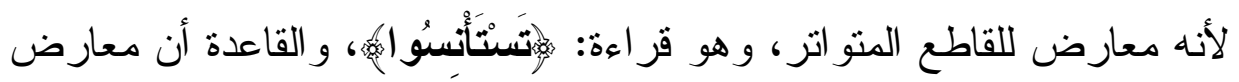

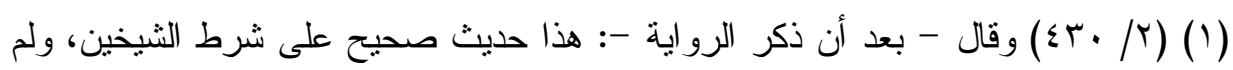

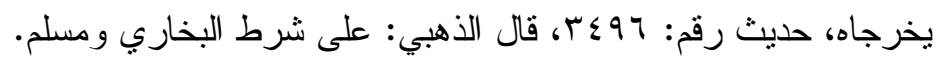

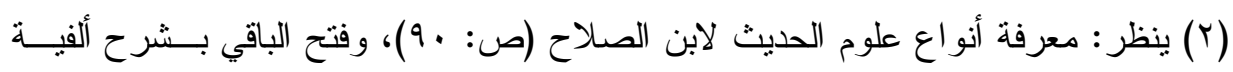

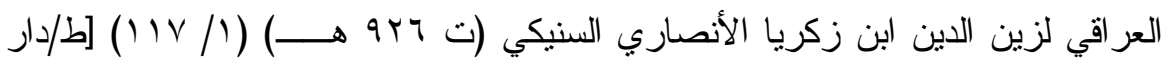

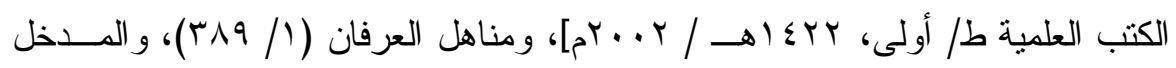

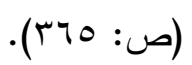

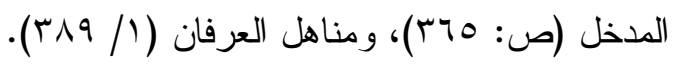

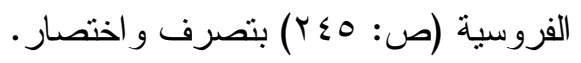

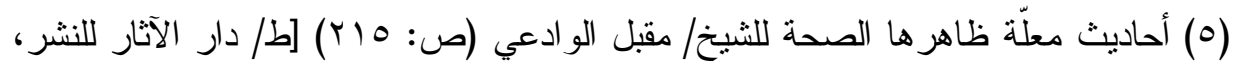

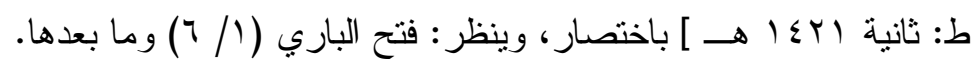


القاطع ساقط، وأن الرواية متى خالفت رسم المصحف فهي شاذة لا يلتفت إليها ولا يعول عليهاه" (') • كما أنها رواية آحاد، لا تقوى على معارضة الثابت، و لا يثبت بها

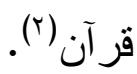

\section{مهاولات لالتوفيرق:}

ا - قيل بالجمع بين القراعتين: فيحتمل أن تكون اتتنأذنواه هي القراءة

الأولى، ثم صارت القر اءة إلى ما عليه العامة(؟).

أقول: و هذه الاحتمال غير موفق؛ لأن قر اعة اتشتأذنو اه غير ثابتة عن ابن

عباس (ء).

فكيف نجمع بين منو اترة، وبين قر اءة فيها مقال؟ فالقرّاء لم يرووا غير

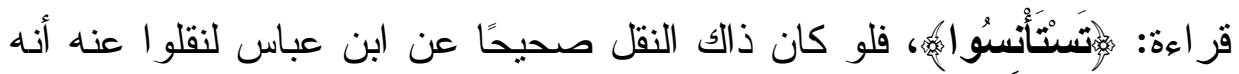

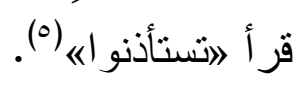

r- وقيل: إن جملة: 》خطأ من الكاتبه محمولة على أنه أخطأ في اختيار

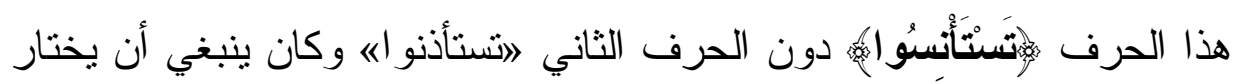

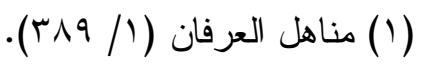

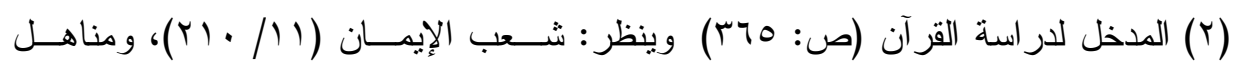

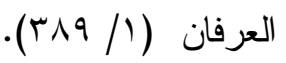

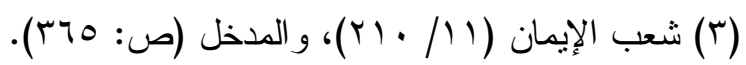

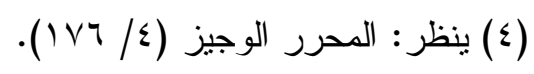

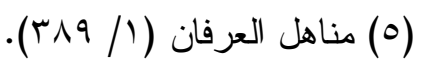


الثاني، لأنّه أبين وأوضح دلالة على المعنى، ولأنّ معناه محدود، إذ ليس في اللفظ تجوزّ و لا اثشتر الى (').

أقول: وهذا كلام في غاية الضعف، فمن هو هذا الكاتب الذي عهد إليه

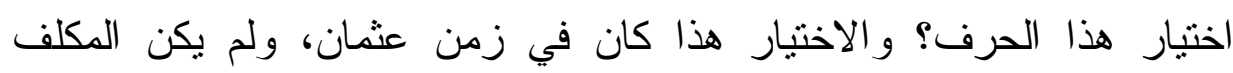

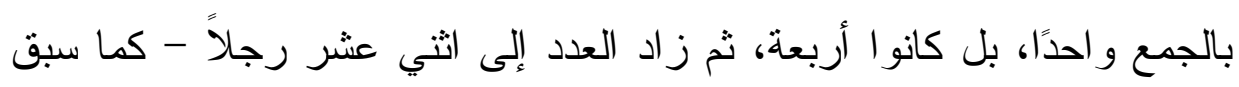

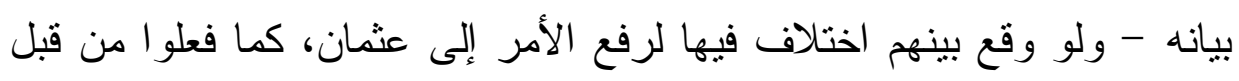
في الرجوع إلى عثمان عند اختلافه في لفظ: »التابوته، وهي اللفظة الوحيدة التي اختلفو ا في رسمها(؟). و على فرض أن الكاتب المقصود هو زيد بن ثابت، و أنه أخطأ في اختيار هذا اللفظ، فأين باقي من كانو ا معه من الصحابة من القرشيين؟ ولماذا سكتو ا؟

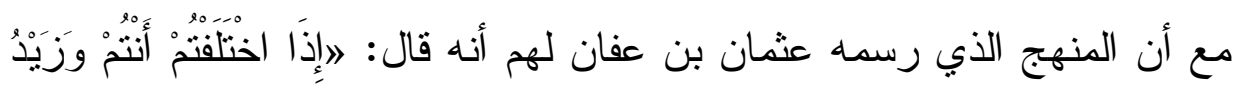

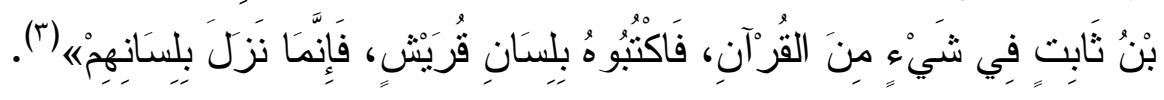
يضاف إلى ذلك أنه لـ يُنقل لنا في أي خبر أن زيد بن ثابت، و الرهط

القرشيين اختلفو ا في هذين الحرفين، ولو كان هناك أي اختلاف لنُقل إليناء؛).

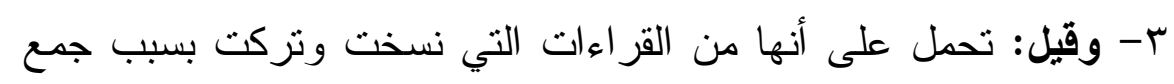
الناس على حرف و احد، و هو حرف قريش، فإنهم التزموا جمع ما ثبت بالتو اتر

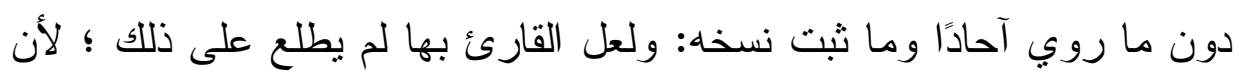

(1) تفسير آيات الأحكام، للشيخ محمد علي الـسايس (ص: 1/OV) [ط/ المكتبــة العـصرية

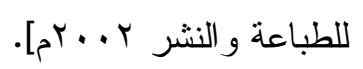

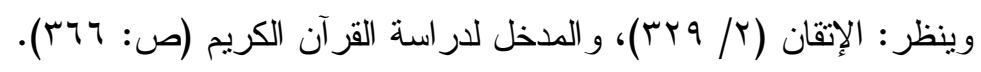

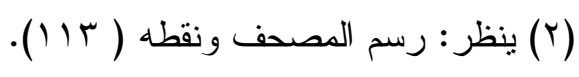

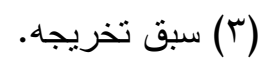

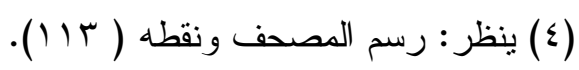




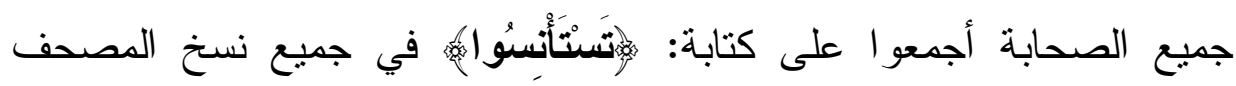
العثماني، وكذا على تلاوتها، ومضى على ذللك إجماع المسلمين في مشارق الأرض ومغاربها في مصاحفهم وتلاوتهم من غير نكير (').

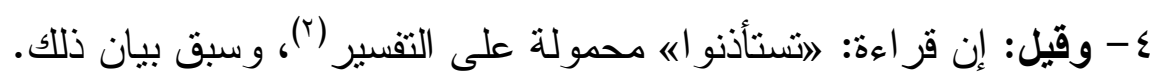

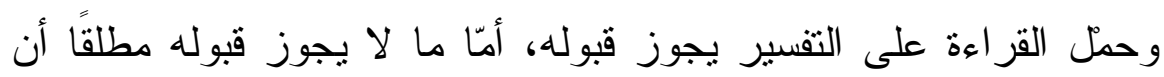
ينسب إلى ابن عباس أنه قال: „خطأ من الكاتبهـ

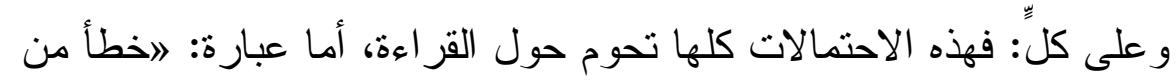

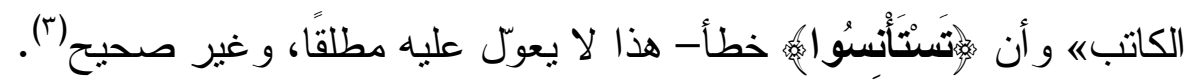

\section{ثالثا: رد الرواية من جهة المتن:}

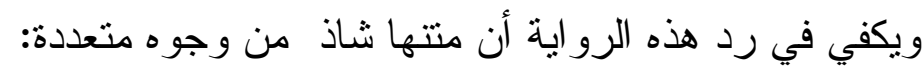

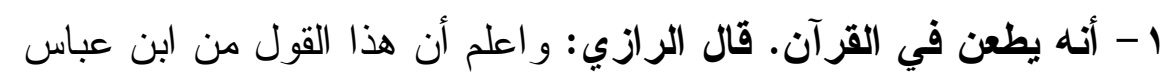

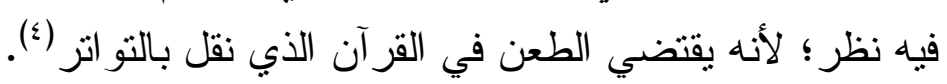

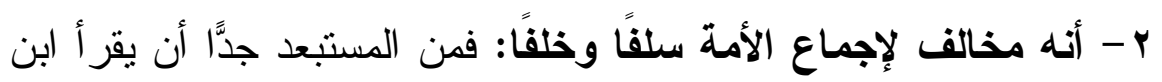

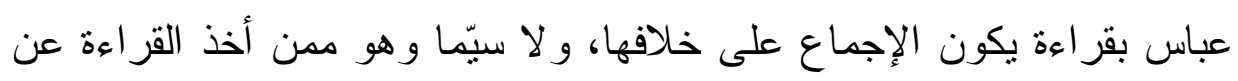

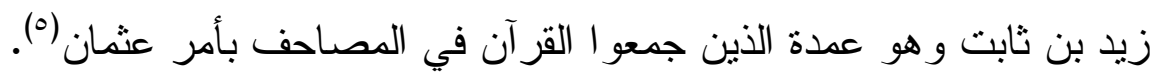

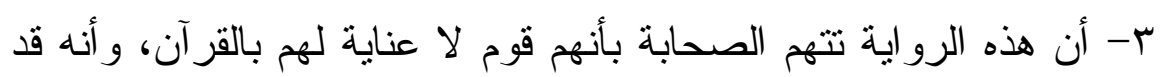

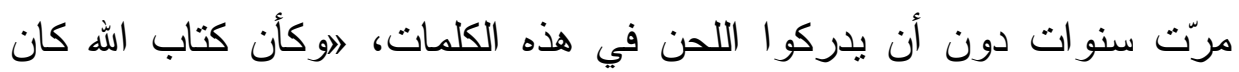

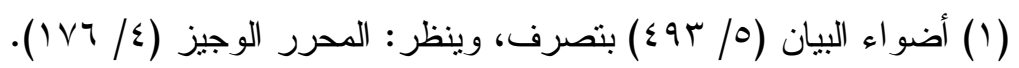

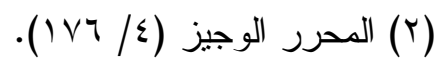

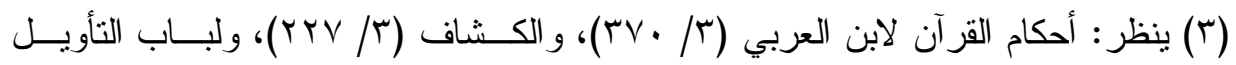

$$
\cdot(r q \cdot / r)
$$

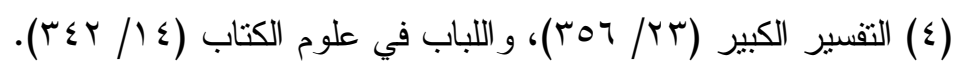

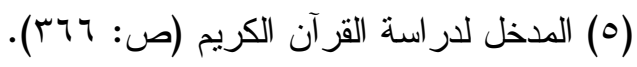


بينهم في مضيعة حتى كتب الكاتب فيه ما شاعوا أو زادوا أو نقصوا، وكأن

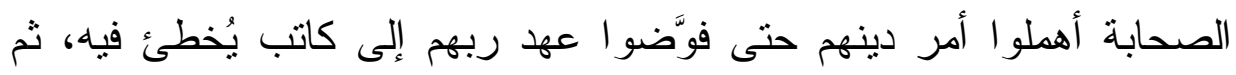

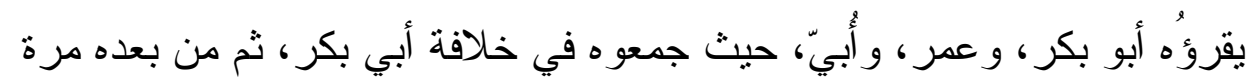
أخرى في زمن عثمان، وهم على الخطأه! (').

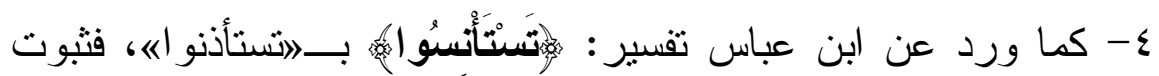

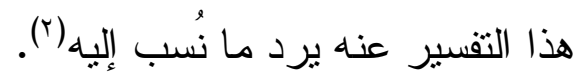
0- ومما ينفي هذا القول عن ابن عباس ما قد سبقت الإثارة إليه، وهو

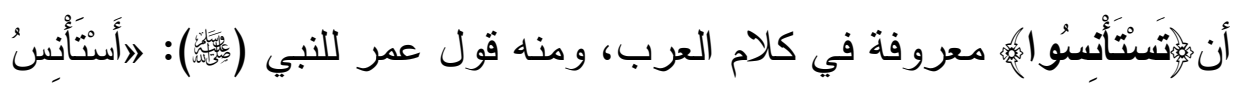

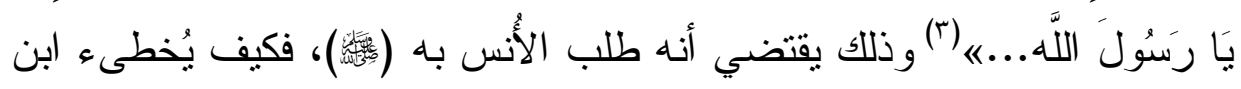

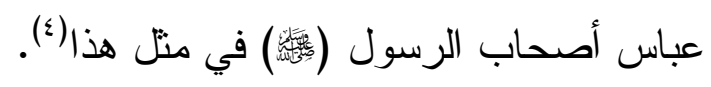

\section{رابعًا: موقفع الهفسرين منها:}

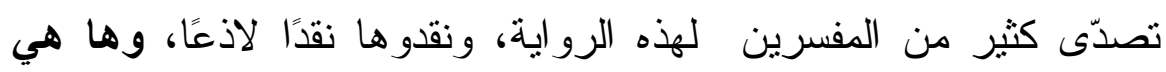

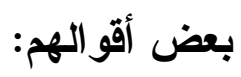

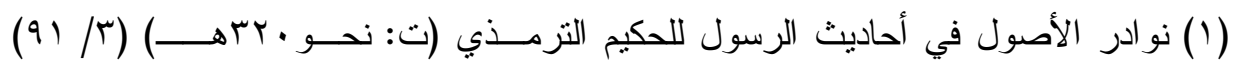

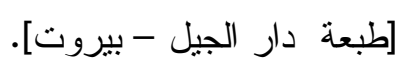

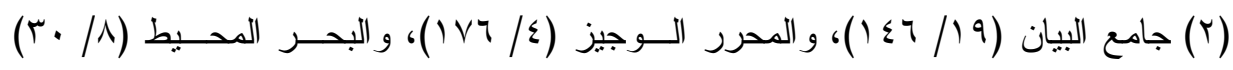

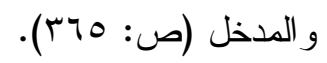

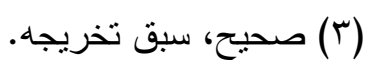

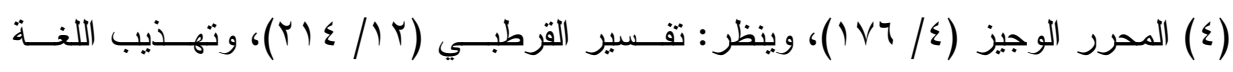

$$
\text { (7./14) }
$$




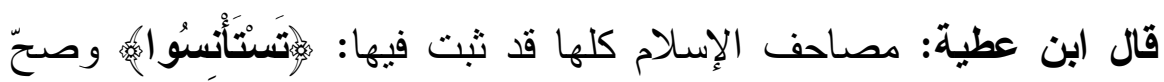

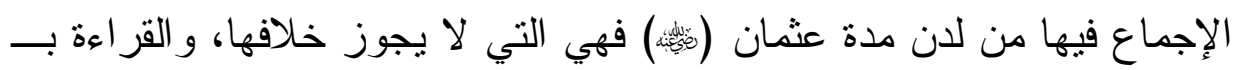
》ايستأذنو ا《 ضعيفة (')

وقال القرطبي: وهذا غير صحيح عن ابن عباس وغيره، فإن مصاحف

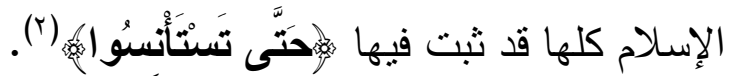
وقال أبو حيّان: من روى ذللك،فهو طاعن في الإسلام ملحد في الدين، و ابن عباس بريء من هذا القول(r).

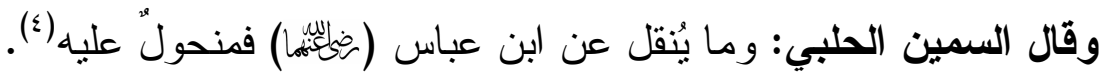
كما تصدى لهذه الرواية غير المفسرين، مثل: ابن بطال، والحكيم

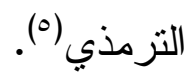

\section{خامسًا: مر|سة موضع الزعم:}

شرع الاستئذان لمن يزور أحدًا في بيته؛ لأن الناس اتخذوا البيوت للاستتار مما يؤذي الأبدان من حر ومطر، وغير ذلك، ومما يؤذي العرض و النفس من ين يلن

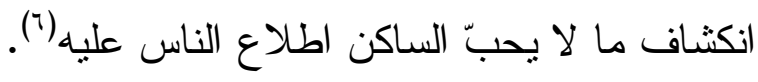

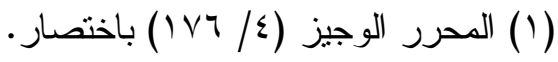

$$
\begin{aligned}
& \text { (Y) تفسير القرطبي (Y) (Y) ع (T) }
\end{aligned}
$$

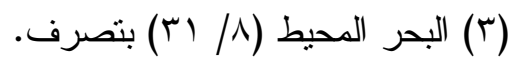

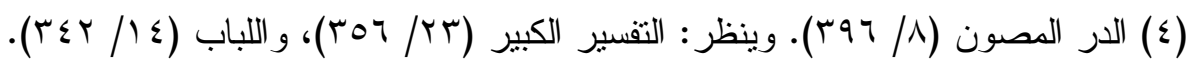

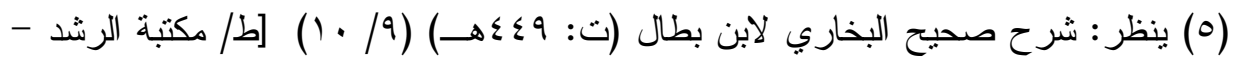

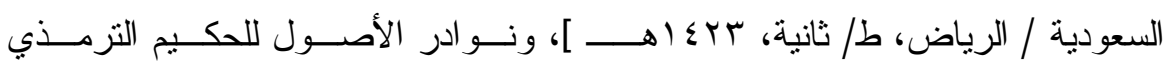

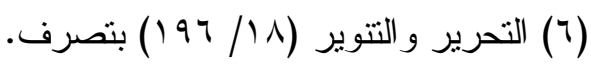




\section{وفي تفسير الاستثنتاس وجوه، منهما:}

1- أنه بمعنى تستأذنو ا، وسبق ذكره.

r- أنه بمعنى الاستعلام، و الاستكثاف: استفعال من أنس الثيء إذاء

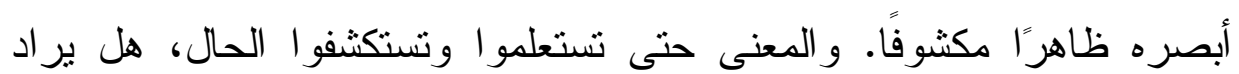
دخولكم أم لا. ومنه قولهم: استأنس هل ترى أحدًا، و استأنستُ فلم أرَّ أحدًا، أبي:

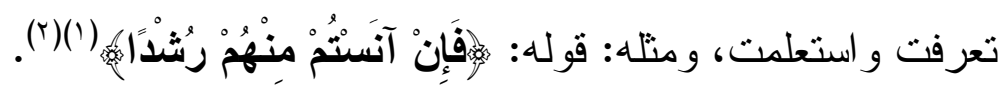

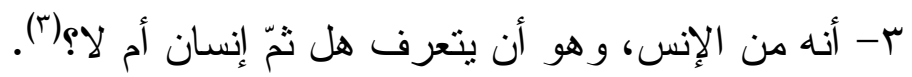

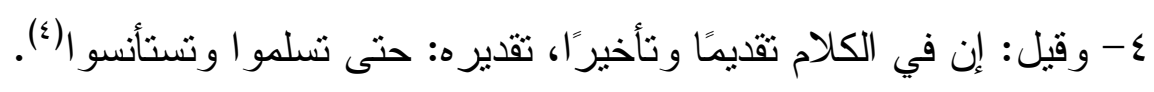
0- وقيل: معناه حتى تؤنسو ا أهل البيت بالتنحنح فيعلموا بقدومك عليهم. قاله مجاهد.

وعن أبي أيوب الأنصاري قَال: قَلْتُ: يا رَسُولَ اللَّه، هَذَا السَََّام، فَمَا

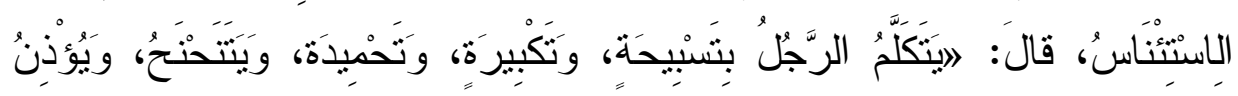

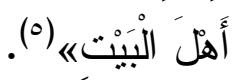

$$
\begin{aligned}
& \text { (1) (1) سورة النساء من الآية: } 7 .
\end{aligned}
$$

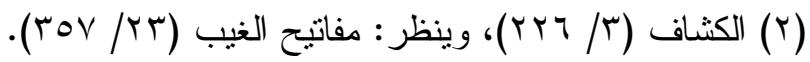

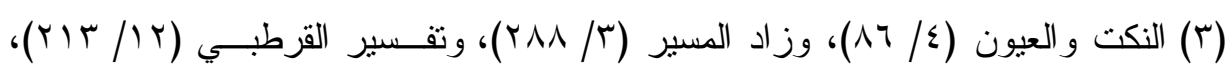

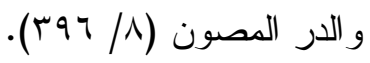

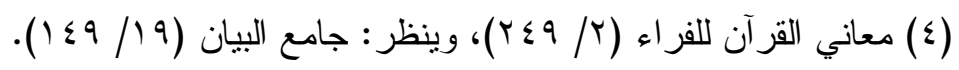

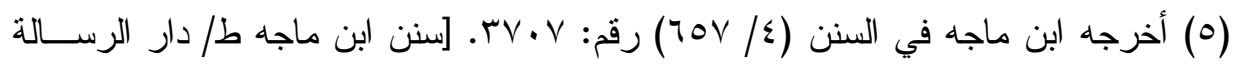

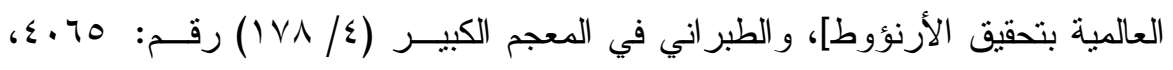

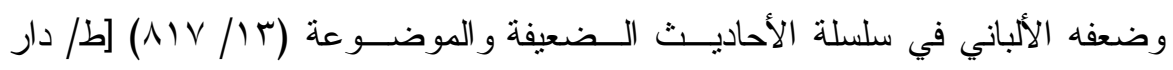

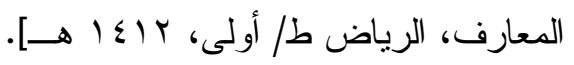


و هذا - إن صحّ-- نص في أن الاستئناس غير الاستئذان، و الاستئناس يكون قبل السلام، وتكون الآية على بابها لا تقديم فيها و لا تأخير، و أنه إذا دخل

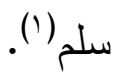
وعلى كلٍٍ: فهذه الوجوه نردّ ما نُسب إلى ابن عباس أنه قال: هي خطأ من الكاتب.

أمَّا الحكمة في التعبير عن الاستئذان بالاستئناس؛ فلأنه مثلكه في معنى

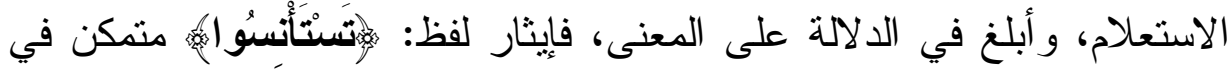
باب الإعجاز من القراءة المزعومة التستأذنواه فالاستئذان ينصرف إلى لى لئى الاستئذان بالقول. و أما الاستئناس فيشمل القول و غيره من الأفعال التي تؤذن بالقدوم،كالتسبيح

و التحميد و التتحنح، وما شابه ذلك (؟). هذا إلى ما تشير إليه القراعة المتواترة من أن يقصد به الأنس وإز الة الوحشة، وعدم إيلام المستأذن عليه، ولا هكذا: التستأنواه فقد يكون الاستئذان

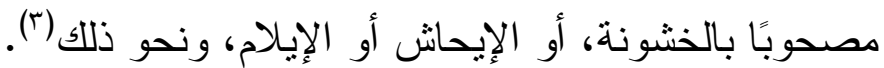

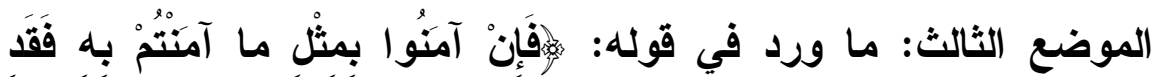

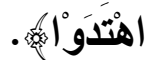

قال الطبري: حدثنا محمد بن المثثى قال: حدثا محمد بن جعفر قال: حدثا

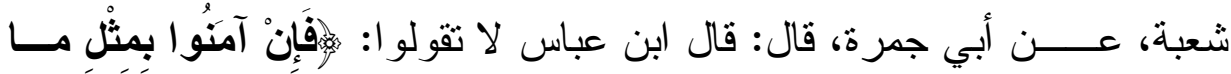

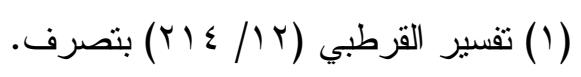

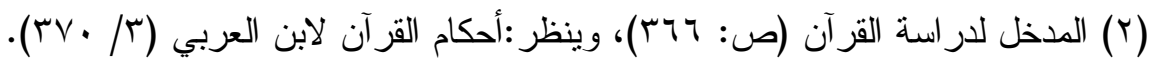

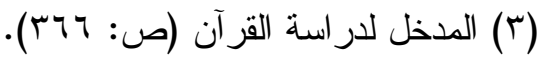




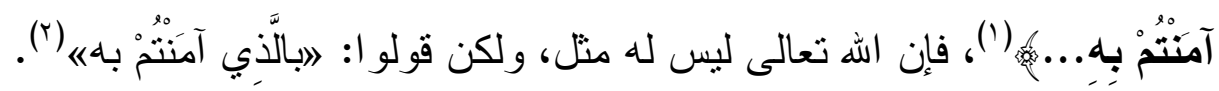

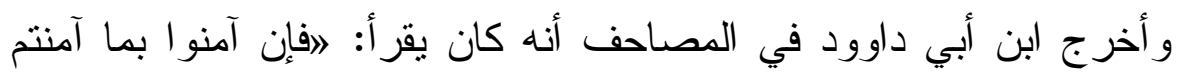

بها《 (r)

قال الزاعمون: فهذا ينفي القر اءة الششهورة التي كتب بها المصحف، ويدل

على أن الدصحف قد حصل فيه تغيير (i).

\section{دراسة الرغمم والمكم عليه}

\section{أولاً : الد|فع لهذ|الزعم:}

الدافع لهذا الزعم هو ما جاء في الراوية "إن الله تعالى ليس له

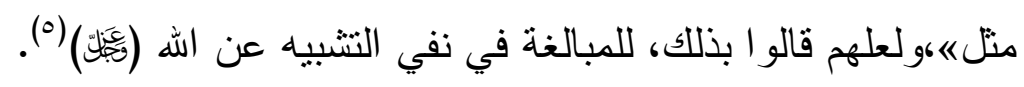

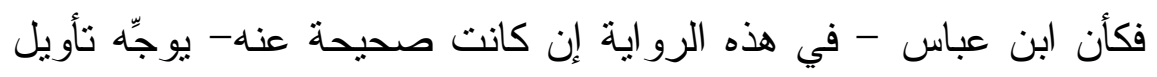

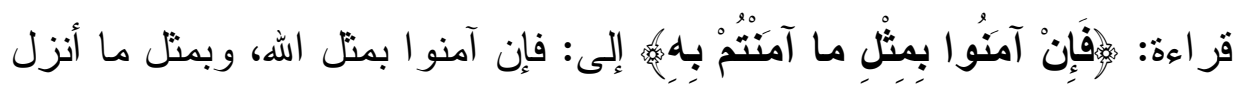

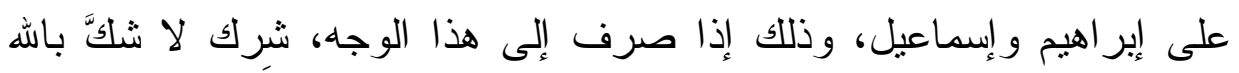
العظيم؛ لأنه لا مثل لله تعالى، فنؤمن أو نكفر به إَ).

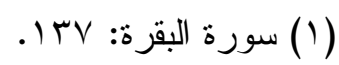

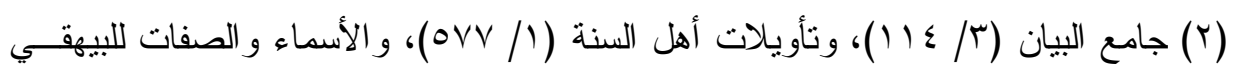

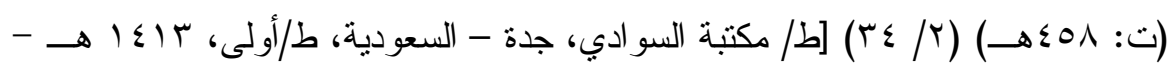

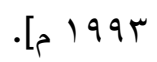

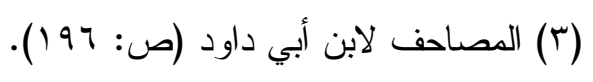

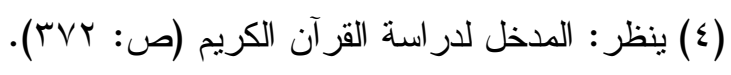

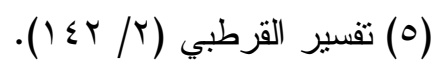

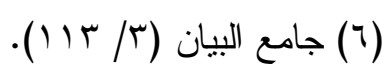




\section{ويرد على هذا الدافع بما يلي:}

أن تأويل ذلك على غير المعنى الذي وَجّه إليه تأويله، فالتمثيل وقع بين

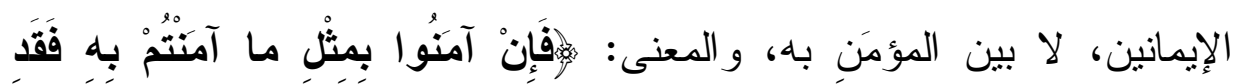

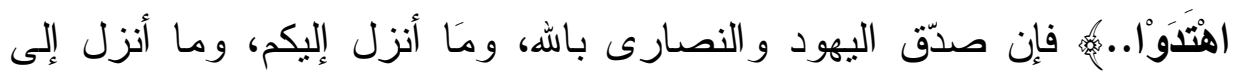
إير اهيم و إسماعيل و إسحاق ويعقوب و الأسباط، وما أوتي موسى و عيسى، وما

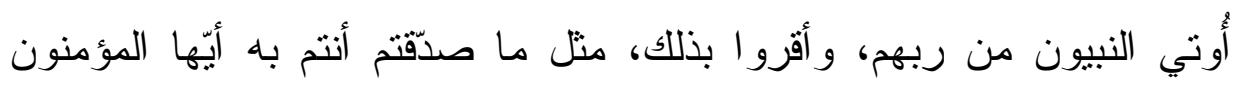

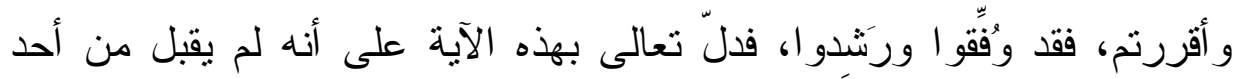
عملاً إلا بالإيمان بهذه المعاني التي عدَّها قبلها، فالتشبيه إنما وقع بين الإهيه التصديقيْن و الإقر ارين اللذين هما إيمان هؤلاء، و إيمان هؤ لاء (').

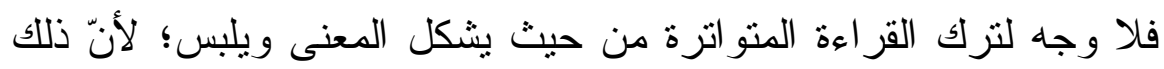
إن جعله المرء مذهبًا لزمه أن يغير تلاوة كل الآيات المنشابهات، وهذا

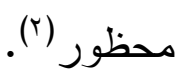

\section{ثانيًا: الحكم على الرواية من جهة الإسناد:}

لم أقف على حكمٍ لإسناد هذه الرواية -فيما اطلعت عليه- ويكفي في الحكم عليه أن من ذكروا هذه الرو اية قامو ا بردها ردَّا قاطعًا، فقد قال الطبري فيها:

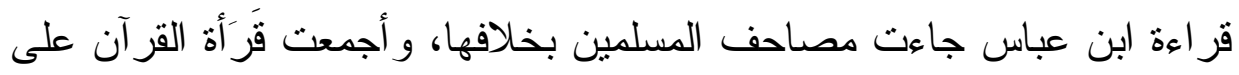

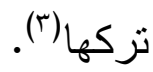

$$
\begin{aligned}
& \text { (1) جامع البيان (T/ T/ (1) وما بعدها بتصرف. }
\end{aligned}
$$

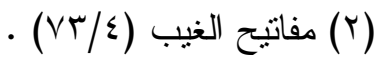

$$
\begin{aligned}
& \text { (r) جامع البيان (r/ ع (1) (1). }
\end{aligned}
$$


وقال ابن أبي داوود-بعد أن ذكرها-: و لا يجوز أن يجتمع أهل الأمصار

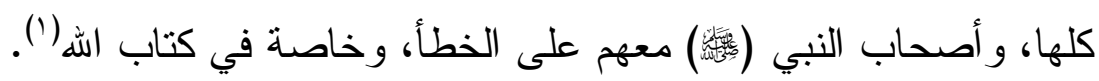

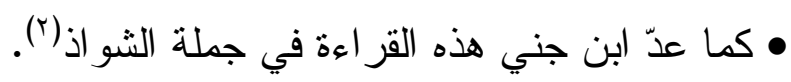

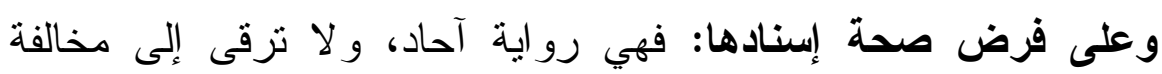

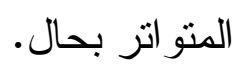

ويمكن أن تحمل على التفسير وبيان المعنى للقر اءة المنو اترة(؟).

\section{ثالثا: رم الرواية من جهة الهتن:}

• هذه الرواية مخالفة للقطعي الثابت بالتو اتر ، و الذي أجمع عليه المسلمون

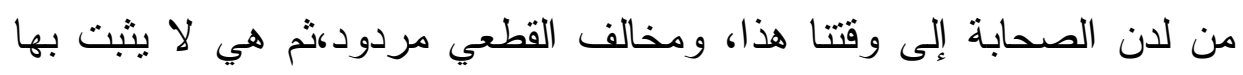

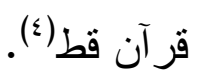

• كما أن متتها يشتمل على ما يطعن في القرآن، فكيف استطاع ابن عباس

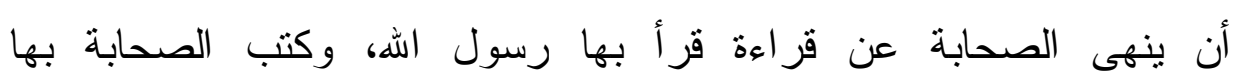

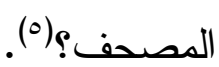

\section{رابعًا: در|سة موضع الزعم:}

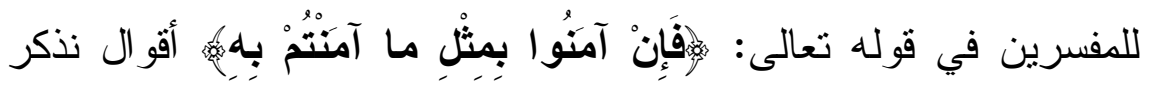

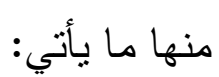

$$
\text { (1) (1) المصاحف لابن أبي داود (ص: } 97 \text { (1)). }
$$

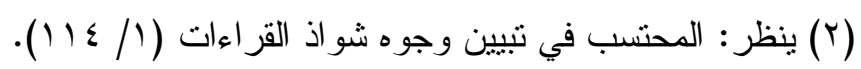

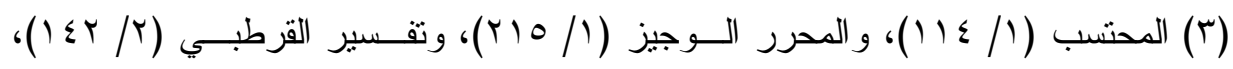

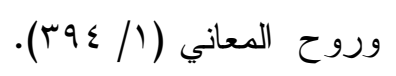

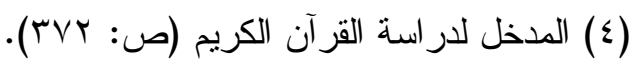

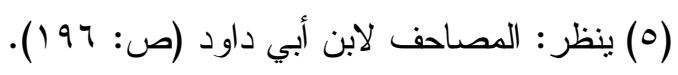




$$
\text { أحدها: أن معناه: منل إيمانكم، فزيدت الباء للتوكيد. }
$$

والثاني: أن المر اد 》منْله الكتاب، وتقديره: فإن آمنو البكتابكم كما آنتنم بكتابهم.

والثالث: أن المنل هاهنا: صلة، و المعنى: فإن آمنو ا بما آمنتم به. والرابع: هذا من مجاز الكلام، يقول: هذا أمر لا يفعله مثلاك، أي لا تفعله

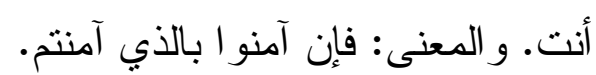

والخامس: أن المثليّة هنا متعلقة بالاعتقاد، أي فإن اعتقدو ا منت اعتقادكم.

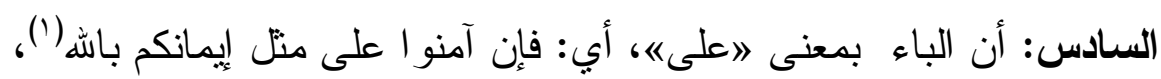
و القول بزيادة الباء، غير مقبول، و التأويل الذي قدمناه عن الطبري في معناها

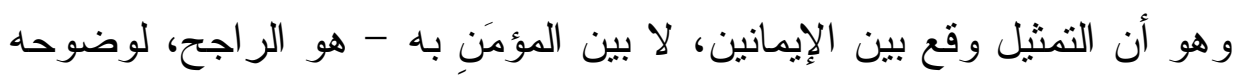

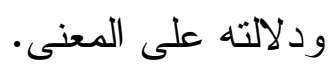

\section{الإلب الثالث}

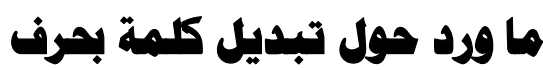

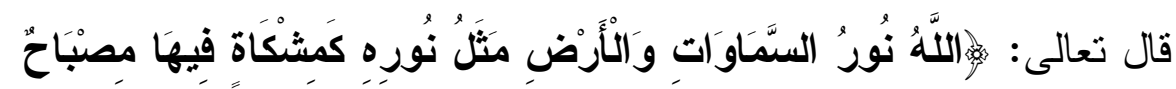

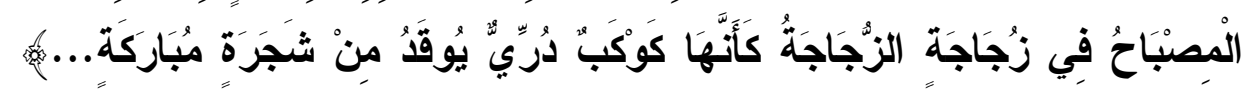

الآية)(r)

زعم الز اعمون وقوع الخطأ في كتابة بعض كلمات القرآن، ومن ذللك ما ورد فيما أخرجه ابن أبي حاتم قال: حدثنا علي بن الحسين، حدثنا نصر بن

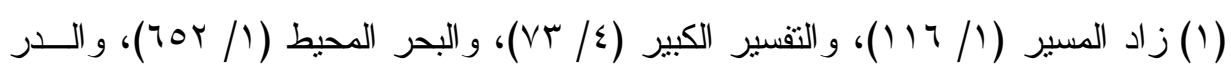

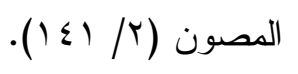

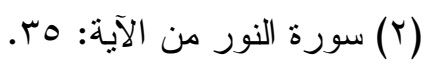


علي، أخبرني أبي عن شبل بن عباد عن قيس بن سعد عن عطاء عن ابن

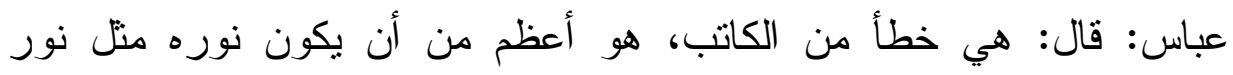
المشكاة، قال: مثل نور المؤمن كمشكاة: (1).

\section{دراسة الرعمم والمكم عليه}

\section{أولاً: الد|فع لهذ|الزعم:}

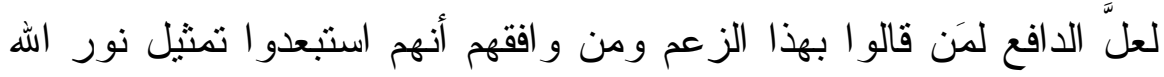

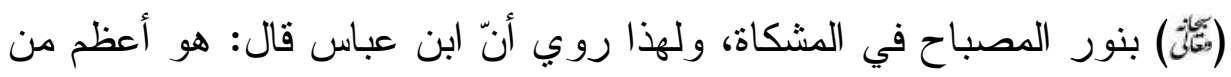

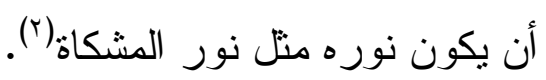

\section{وهذ||لاففع مردود:}

لأنه 》لا وجه لهذا الاستبعاد، و لا وجه للعدول عن الظاهر، لا من كتاب،

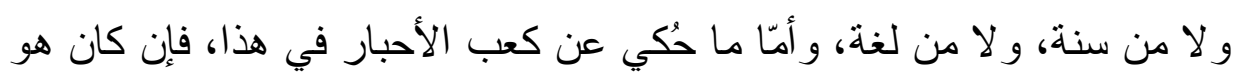

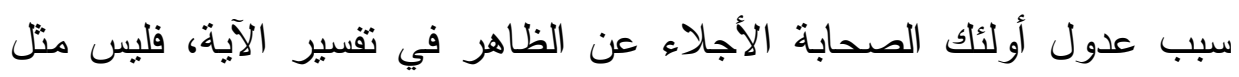

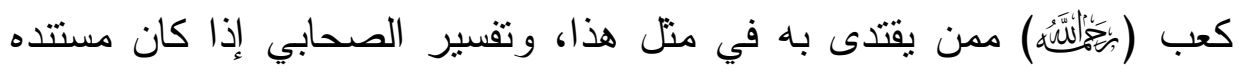

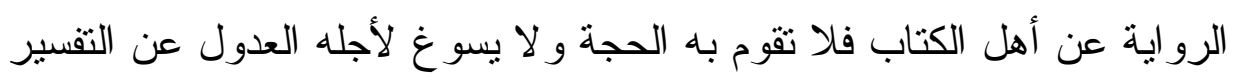

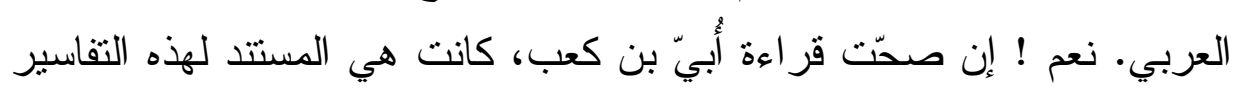

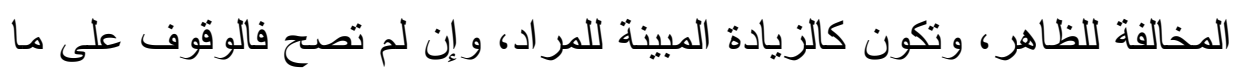

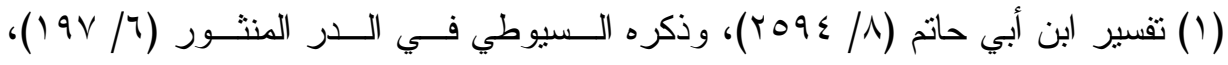

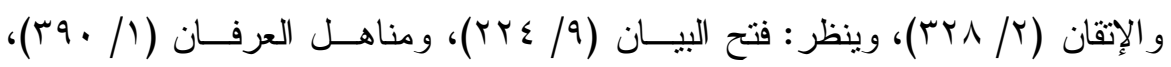

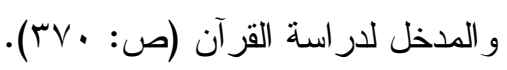

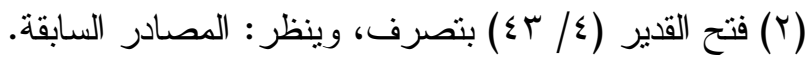


تقتضيه قر اعة الجمهور من السبعة، وغيرهم ممن قبلهم، وممن بعدهم هو

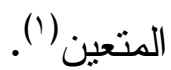

\section{ثانيًا: الحكم على الرواية من جهة إلسناد:}

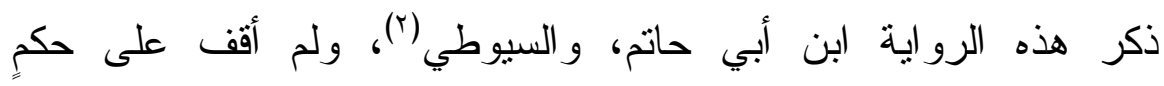

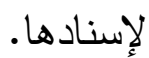

وقال الزرقاني- بعد أن ذكرها-: هي رو اية ساقطة(").

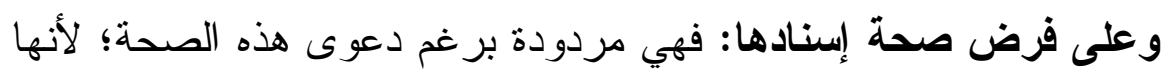

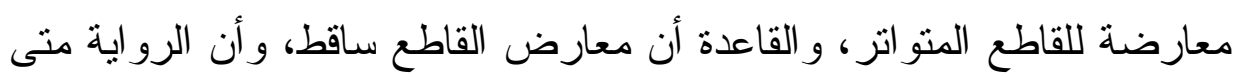

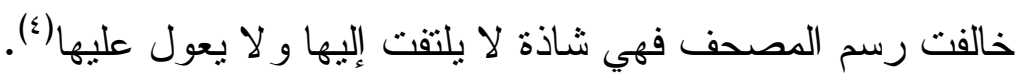

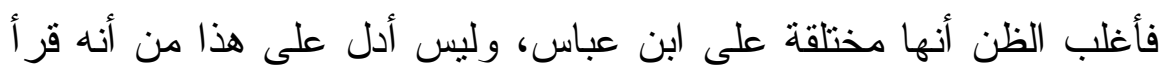

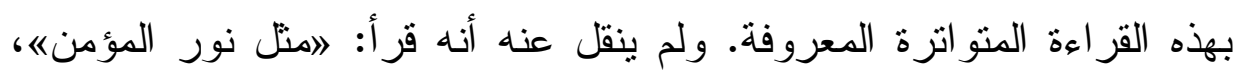

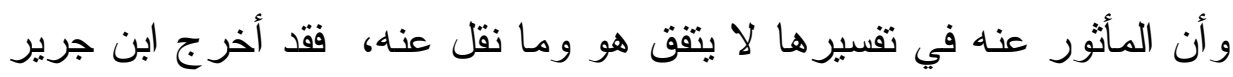

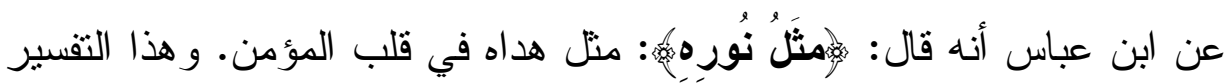

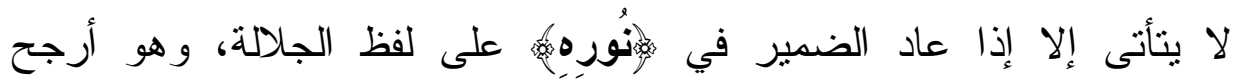

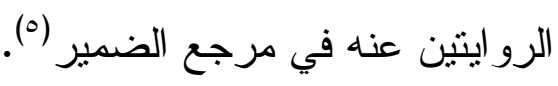

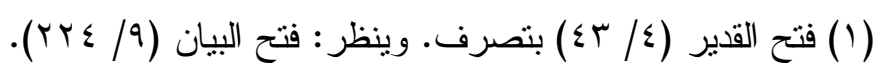

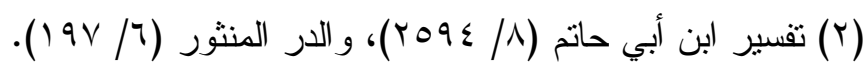

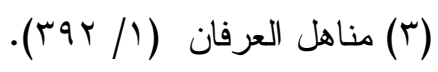

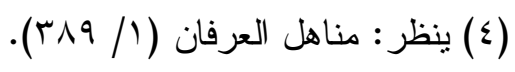

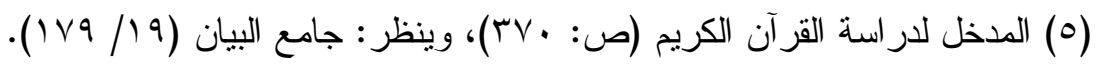


قال أبو شهبة: ولو سلمنا ما رو اه الحاكم عنه من أن مرجع الضمير هو

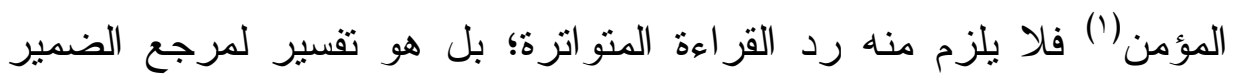

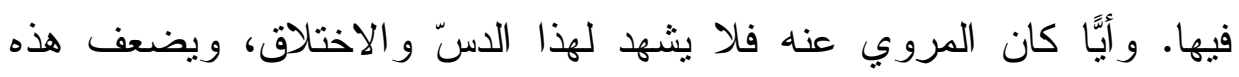

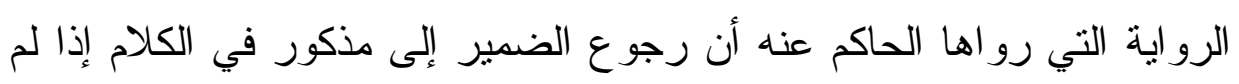

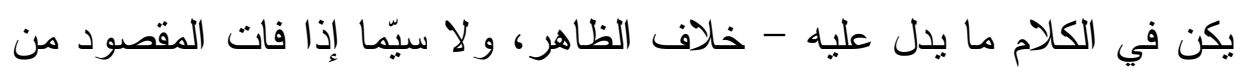

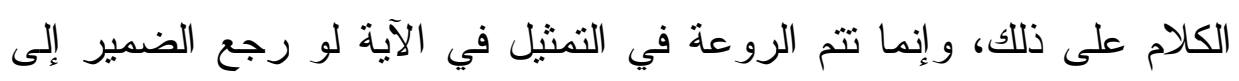
المذكور، وهو لفظ الجلالة، على أن يكون المراد بالنور الحق الذي قامت عليه

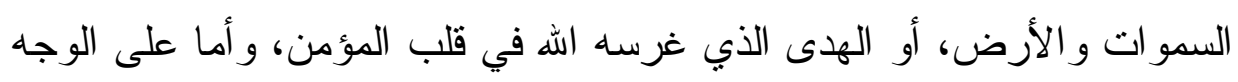

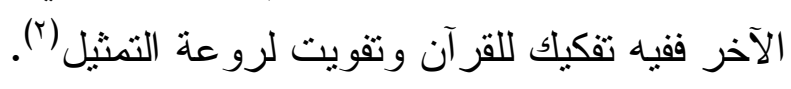

\section{ثالثًا : رو الرواية من جهة الهتن:}

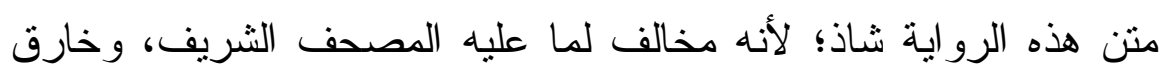

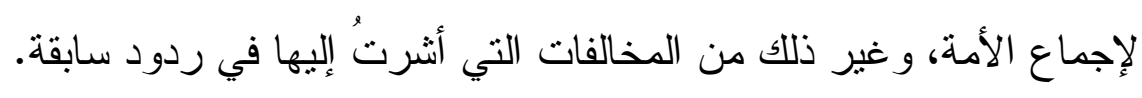

\section{رابعًا: مخالفنها للو|قع:}

هذه الرواية دردودة عقلاً؛ لأن ابن عباس قد أخذ القر آن عن زيد بن ثابت،

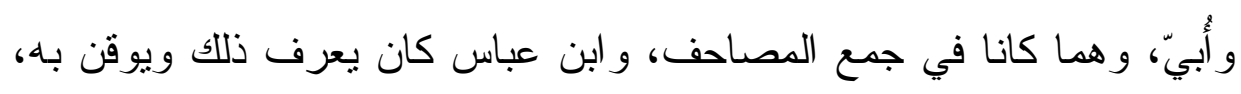

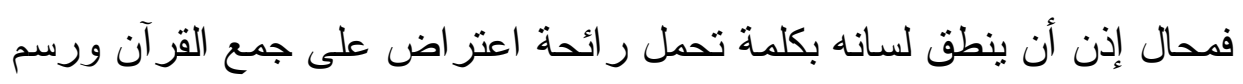
القرآن، وإلا فكيف يأخذ عن زيد وأبي بن كعب ثم يعترض على جمعهما

ورسمهما؟(ان)

( (1) ينظر : المستدرك على الصحيحين (T/ بr ) ).

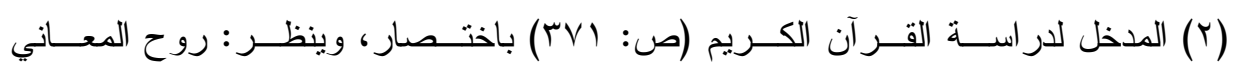
. (r०9/9)

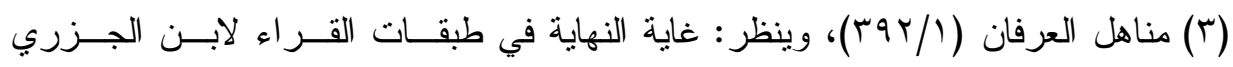
( $(\varepsilon r T / 1)$ 


\section{خامسًا: موقفه الهفسرين منها:}

تجاهل جمهور المفسرين هذه الرواية، ولم يذكروها في تفاسيرهم، وهذا

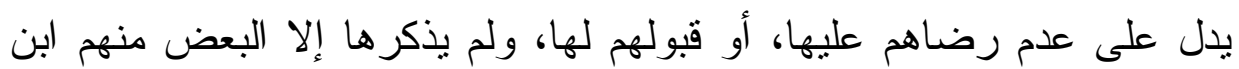

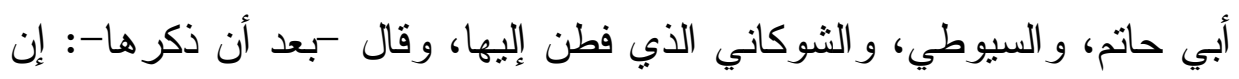
تقسير النظم القرآني بهذا ونحوه كما ورد عن أُبيّ بن كعب، و وابن عباس و وابن ولن

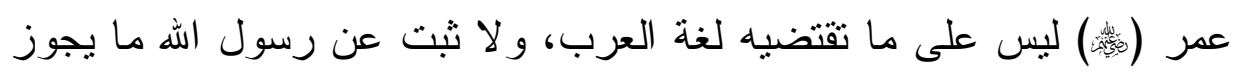
العدول عن المعنى العربي إلى هذه المعاني التي هي شبيهة بالألغاز و التعمية، ولكن هؤلاء الصحابة ومن و اققهم ممن جاء بعدهم استبعدوا تمثيل نور الله سبحانه بنور المصباح في المشكاة، ولا وجه لهذا الاستبعاد. و لا وجه للعدول عن الظاهر، لا من كتاب و لا من سنة و لا من لغة (').

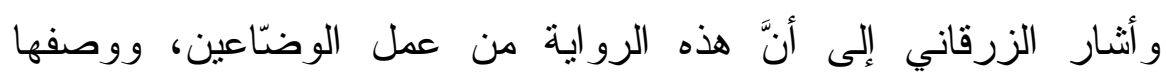

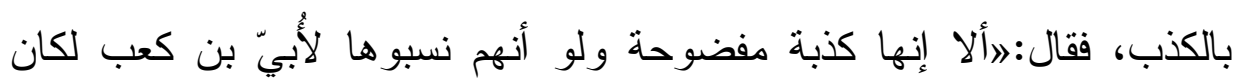
الأمر أهون؛ لأنه روي في الثواذ: أن أبي بن كعب قرأ: منل نور المؤمن، إنها و الذي ينبغي أن تحمل عليه هذه الروايات أن أُبيّ بن كعب أر اد تفسير الضمير

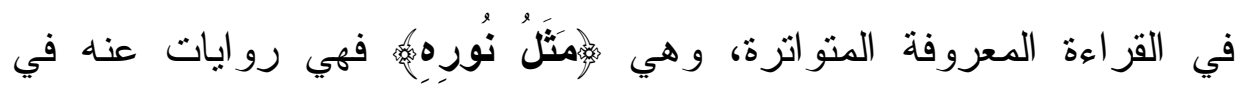

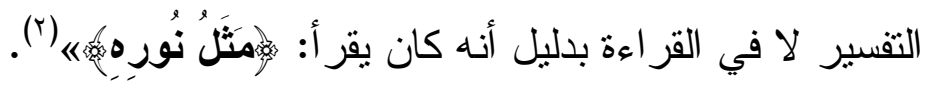

\section{سامسًا: مر|سة موضع الزعم:}

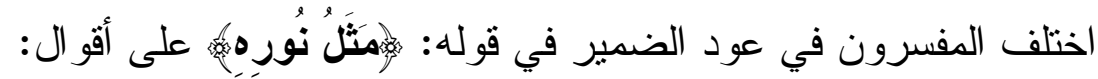

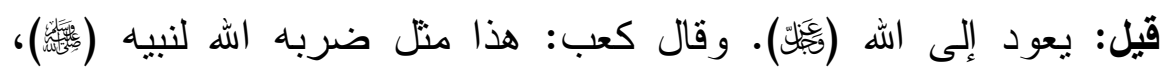
فالمشكاة صدر ه، و الزجاجة قلبه، و المصباح فيه النبوة تتوقد من شجرة مباركة

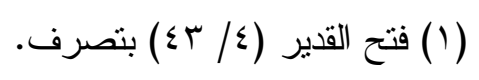

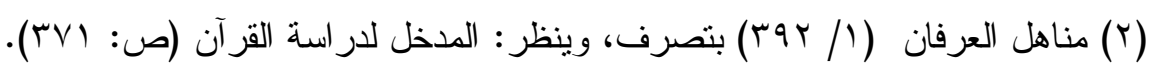




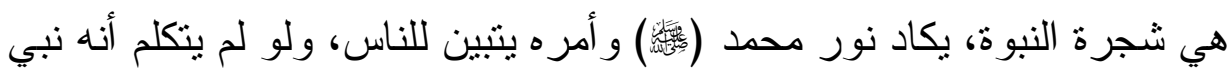
كما يكاد ذلك الزيت يضيء، ولو لم تمسسه نار • وقيل: يعود إلى المؤمن، أي: مثل نور المؤمن الذي في قلبه كَشْكُةاة. وقيل: يعود إلى القرآن. وقيل: إلى الإيمان (1) (1) و القول الأول هو الراجح؛ لأنه الذي يدل عليه ظاهر الآية، والمعنى: مثل نور الله (ئملّ) الذي يهدي إليه في قلوب المؤمنين كمشكاة. و لا حرج من أن يشبه نور الله بنور المصباح في المشكاة، لأنّ هذا هو ما

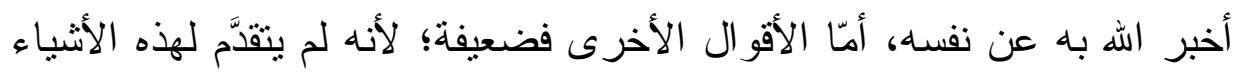
ذكر ، وليس عليها دليل من كتاب أو سنة(؟). و لا يخفى أن رجوع الضمير إلى غير مذكور في الكلام إذا لم يكن في

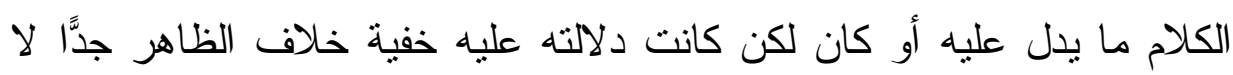
سيّما إذا فات المقصود من الكلام على ذلك (ץ). ومن ثنَّ فمن استبعد تشبيه نور الله (ونَّاّ) بنور المصباح في المشكاة، فقد عدل عن الظاهر، و لا وجه لعدوله من كتاب، أو سنة، أو لغة. كما سبق بيانه. و الله أعلم. عن. عن

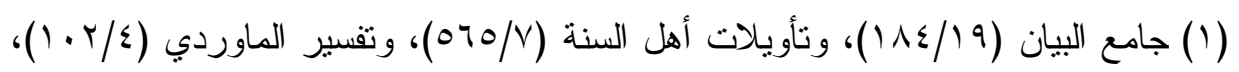

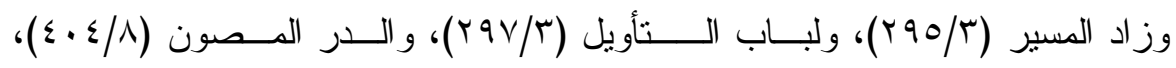

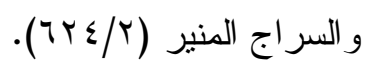

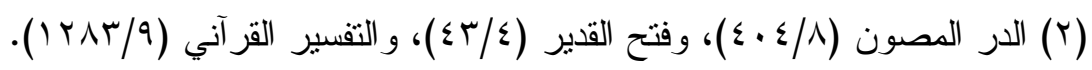

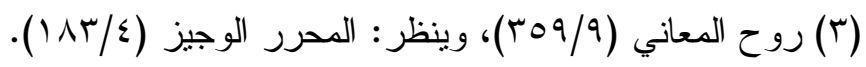




\section{الإطhب الرابع}

\section{ما ورد هول خطأ الكاتب في تبديل بهض المروف}

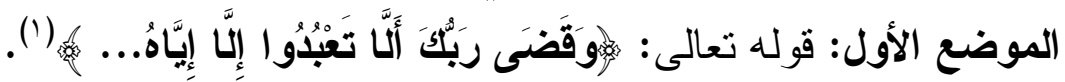

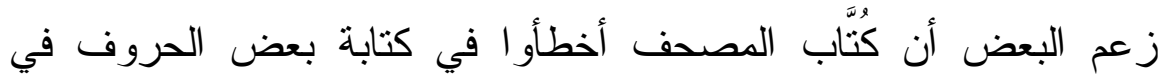
القر آن، بسبب المداد المستخدم في الكتابة، ومن ذلك: ما روي عن ابن عباس أنه كان يقول: أنزل الهه هذا الحرف على لسان نبيكم الوصنَّى ربك أن لا تعبدو ال إلا إيّاه《 فالتصقت إحدى الو اوين بالصاد فقر أ الناس: اوقضى ربكه ولو نزلت لت علي القضاء، ما أشرك به أحد (r). وعن الضحاك قال: ليس كذلك نقرؤها نحن ولا ابن عباس إنما هي ״ووصى ربكه وكذلك كانت تقر أ وتكتب فاستمدَّ كاتبكم فاحتمل القلم مدادًا

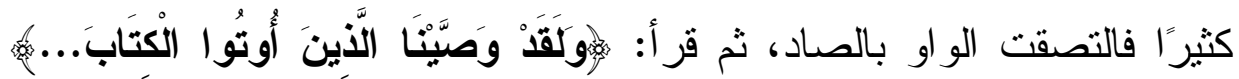
الآية(r) ولو كانت 》قضى" من الرب لم يستطع أحد رد قضاء الرب ولكنه وصية أوصى بها العباد(أ).

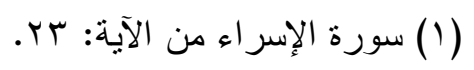

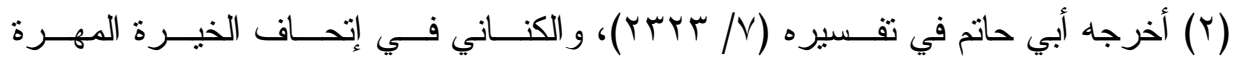

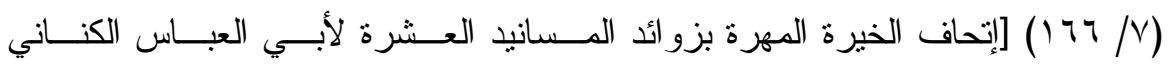

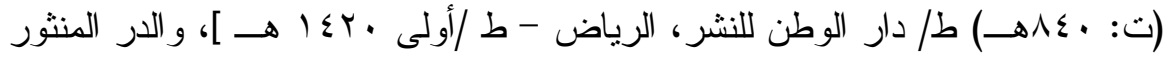

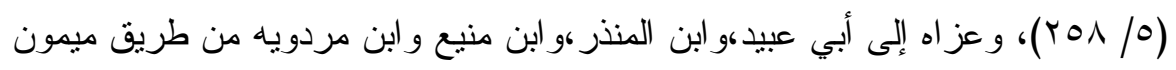
بن مهر ان عن ابن عباس.

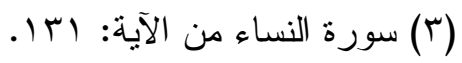

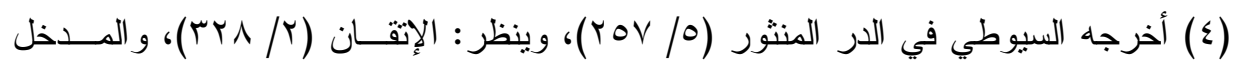

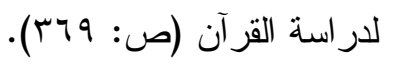




\section{داسمة الزعم والمكم عليه}

\section{أولاً: الد|فع لهذ||الزعم:}

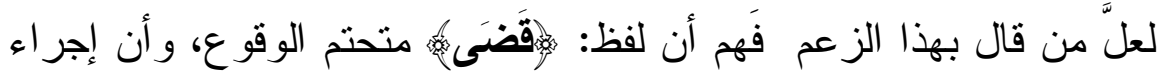

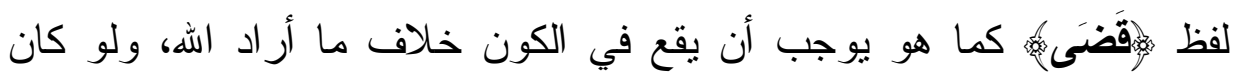

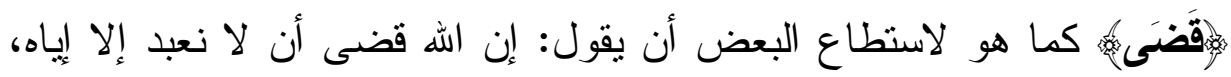

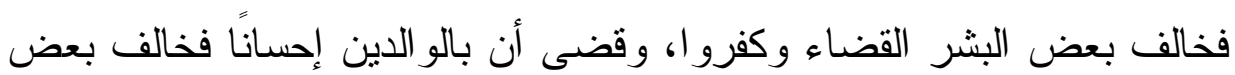

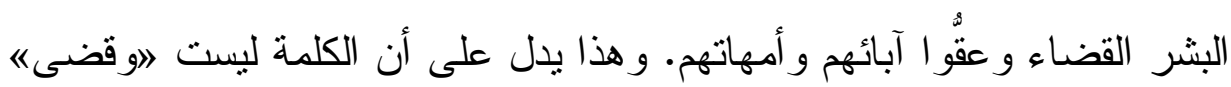

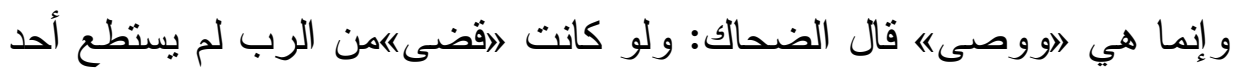

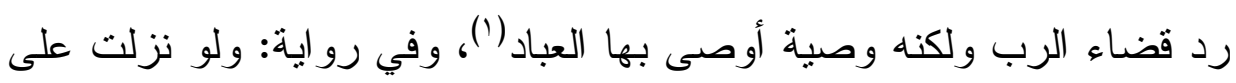

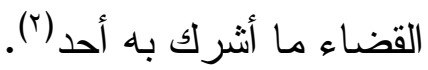

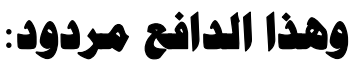

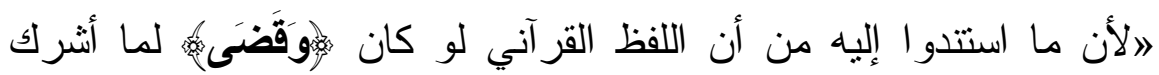

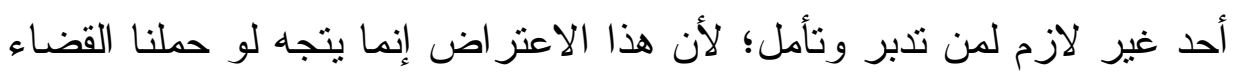

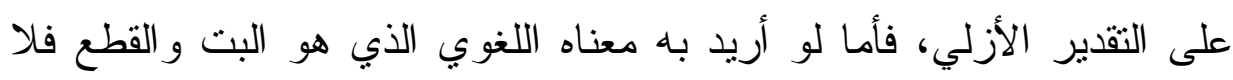

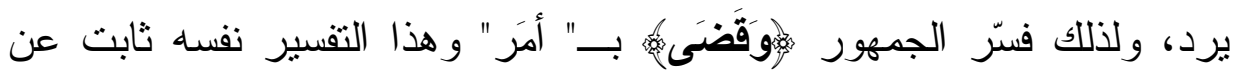
ابن عباس كما أخرجه ابن جرير من طريق علي بن طلحة عن ابن عباس أنه

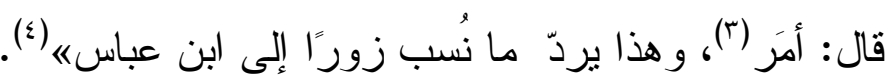

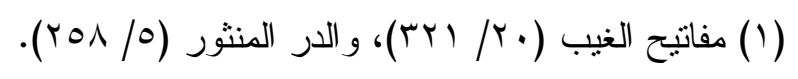

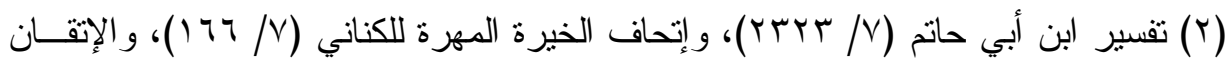

$$
\begin{aligned}
& \text { (TTA / T) }
\end{aligned}
$$

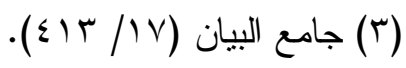

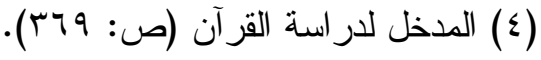




\section{ثانيًا: الحكم على الرواية من جهة الإسنام:}

أخرج هذه الرواية ابن أبي حاتم في تقفيره دون إسناد(')، وأخرجها شهاب الدين الكناني فقال: وقال أحمد بن منيع: حدثنا حسين بن محمد، حدثثا الفرات بن السائب، عن ميمون بن مهران، عن ابن عباس، وذكر الرواية، ثم قال: هذا إسناد ضعيف، فيه فرات بن السائب، ضعفه أحمد بن حنبل، و ابن معين،

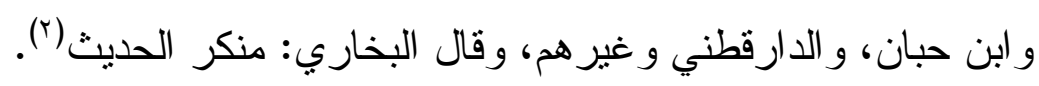

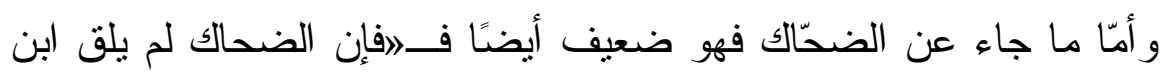

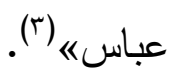

\section{ثالثًا: روها من جهة المتنّ: هذه الرو اية مردودة متنًا لما يلي:}

ا - لأنها تطعن في القرآن، وتخالف المتو اتر الثابت.

ץ- أن متتها اشتمل على ما فيه دلالة على الوضع، فقد جاء فيها الفاستمدَّ كاتبكم فاحتمل القلم مدادًا كثيرًا فالتصقت الواو بالصاده فمن الذي أخبر راوي هذه الرواية بذلك؟ ومن الذي رأى القلم وهو يحمل مدادًا كثيرًا حتى التصقت بون الو او بالصاد؟ و إذا كان هنالك من رأى القلم وهو يحمل مدادًا كثيرًا، ورأى التصاق الو او بالصاد، فلماذا لم يخبر باقي الصحابة وقت الجمع؟ ولماذا سكت؟.

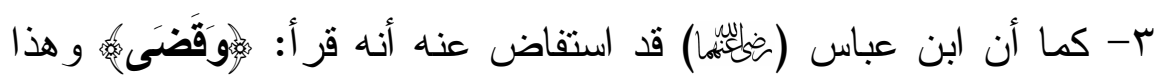
دليل على أن ما نسب إليه غير صحيح، وهذا ما أثنار إليه أبو حيان بقوله: هي

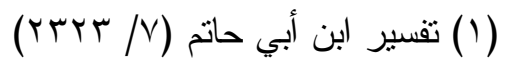

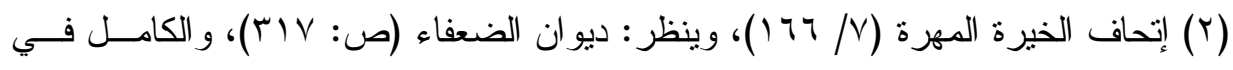

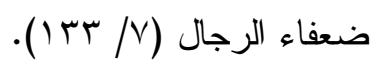




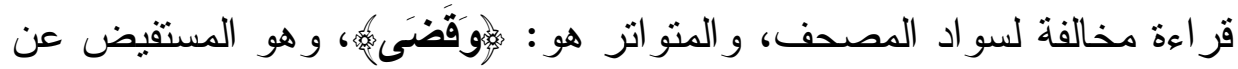
ابن مسعود، و ابن عباس و غير هما في أسانيد القر اء السبعة (').

\section{رابعًا: موقفع الهفسرين منها:}

لقد تصدى كثير من المحققين لهذه الرواية، وبيّن الضعفها، وحكموا بشذوذها، قال الكرماني -بعد أن ذكرها-: وهذه القر اعة عند القراء مقبولة في

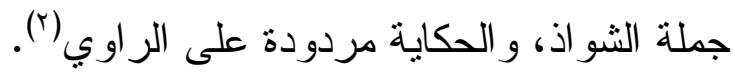
وقال ابن عطية: وهذا ضعيف، و إنما القر اعة مروية بسند (r). وقال ابن الجوزي: وهذا على خلاف ما انعقد عليه الإجماع، فلا يلتقت إلبيه(£)

وقال الرازي: هذا القول بعيد جدًا؛ لأنه يفتح باب أن التحريف و التغيير قد

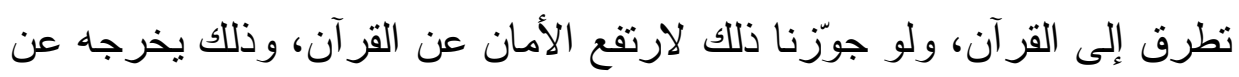
كونه حجة، و لا شك أنه طعن عظيم في الدين (0). وقال أبو شهبة: هذه الروايات ضعيفة، ومدسوسة على ابن عباس ونقلها من نقلها بدون تثبت أو تحرّ، و الضعف لا يحتج و لا يؤخذ به في دون هذا، فما ليا بالك في شيء يتعلق بالقر آن!(؟).

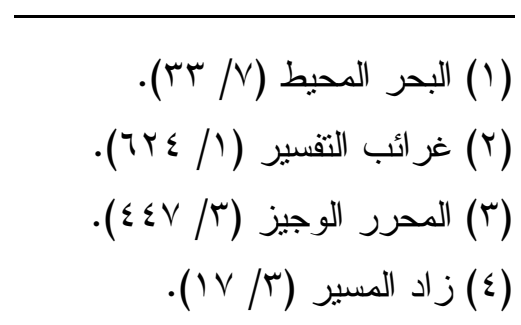

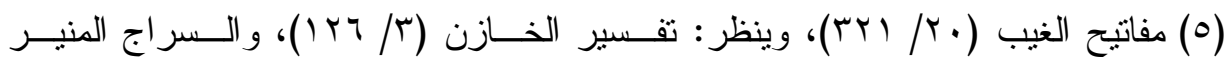
. ( $($ 9 1 / $)$

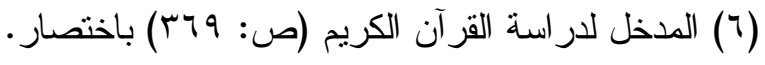




\section{خامسًا: مر|سة موضع الزعم:}

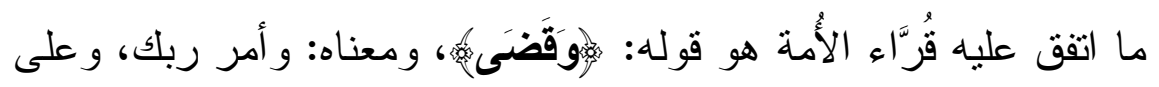

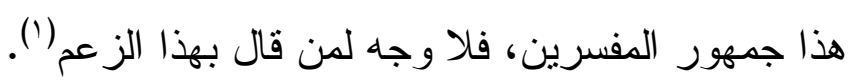

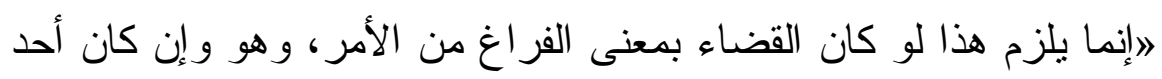

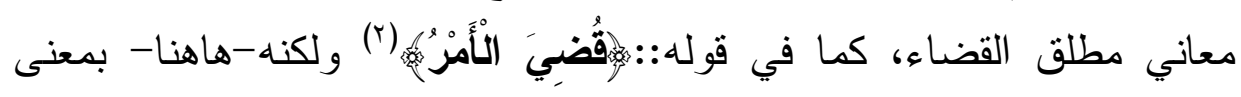
الأمر، وهو أحد معاني القضاء، و الأمر لا يستلزم ذلك، فإنه سبحانه قد أمر عباده بجميع ما أوجبه، ومن جملة ذلك إفر اده بالعبادة وتوحيده، وذلك لا يستلزم أن لا يقع الشرك من المشركينه(؟).

وللتوضيح أقول: القضاء يستعمل في اللغة على وجوه: القضاء بمعنى

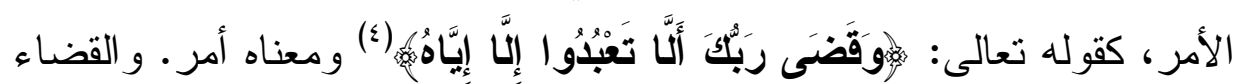

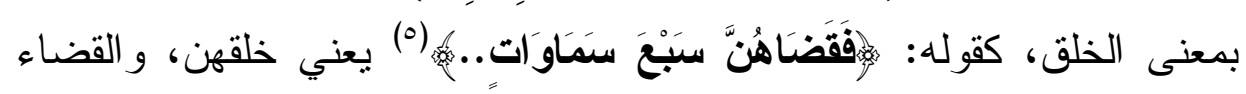

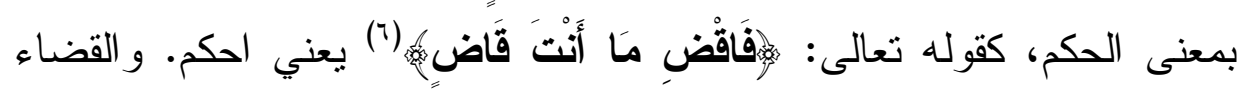

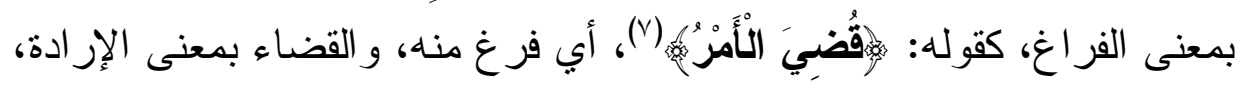

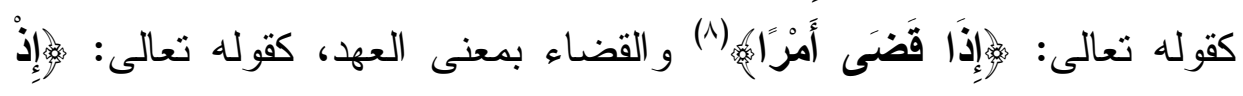

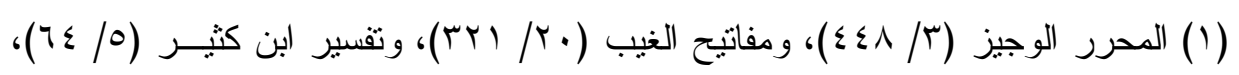

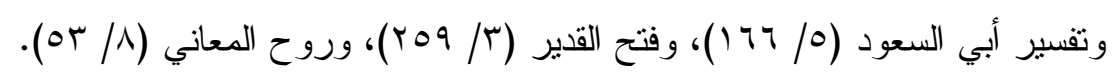

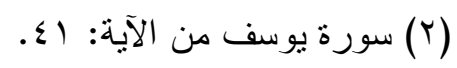

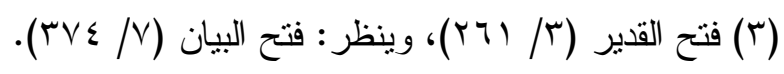

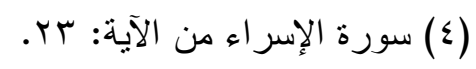

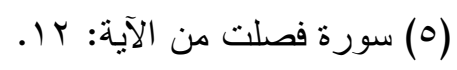

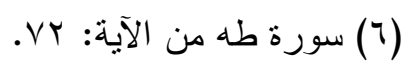

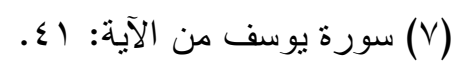

(^) 


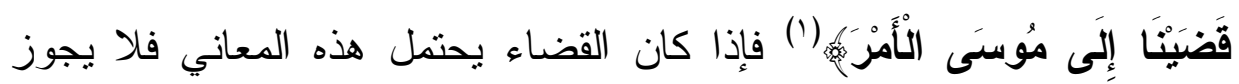

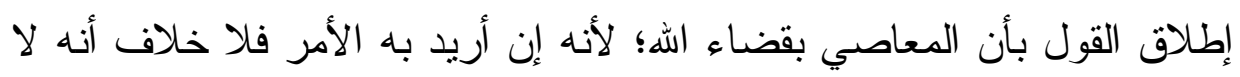

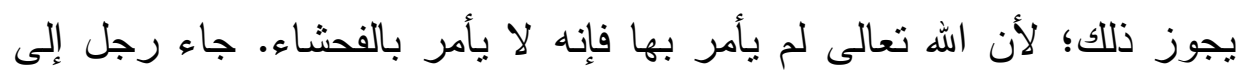

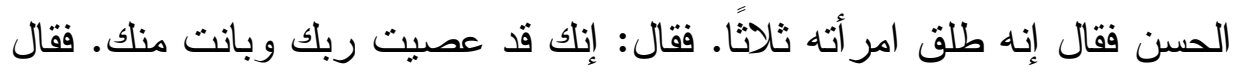
الرجل: قضى اله ذلك عليّ! فقال الحسن: ما قضى اله ذلك، أي ما أمر الهه به،

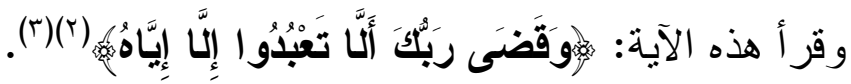
ومما سبق: يتبين أنه لا وجه لمن قال بالخطأ لاندفاع المحذور بحمل

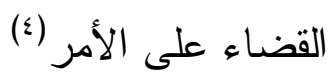

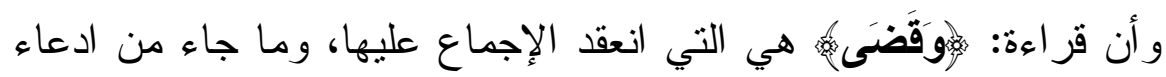
الخطأ في كتابتها، فهو كذب، ومن ثمَّ فلا يتعلق بأذيال منل هذه الرواية الساقطة إلا مُلْحد (0)

\section{الإوضع الثاني:}

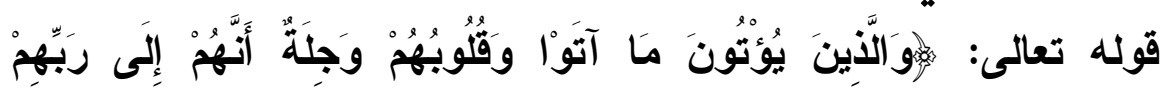

رَاجُونَ

قال الإمسام أحمد: حدثنا عفَّان، حدثنا صخر بن جُوَيَرْيَة، قال: حدَّثنا

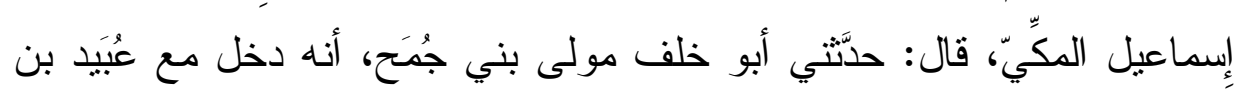

$$
\begin{aligned}
& \text { (1) سورة القصص من الآية: ع؟ ؟. }
\end{aligned}
$$

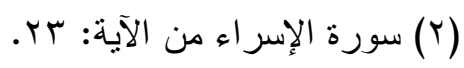

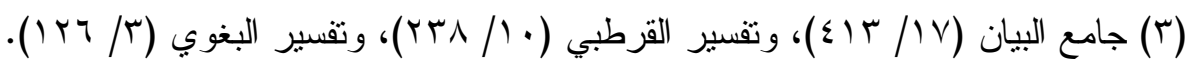

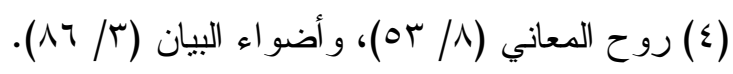

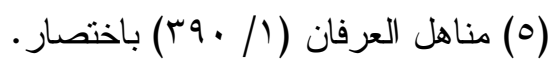

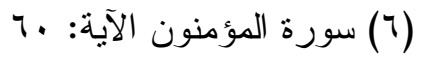




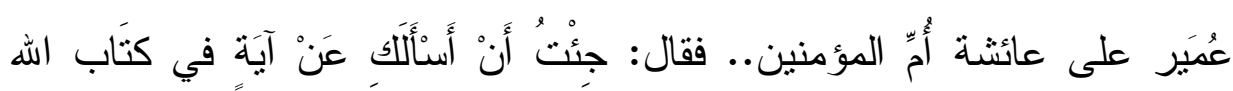

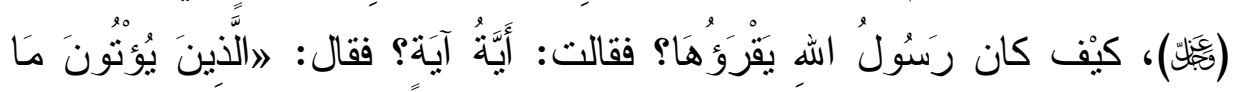

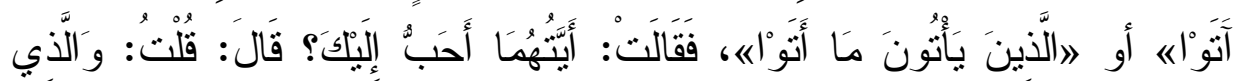

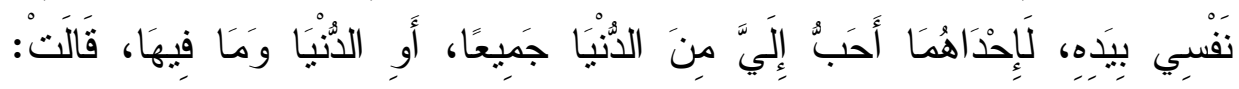

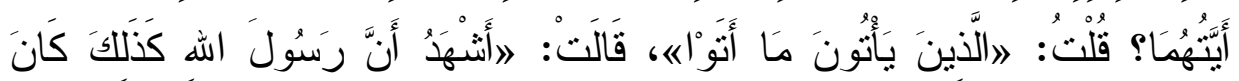

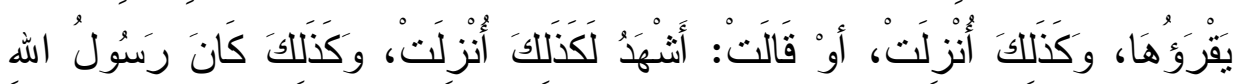

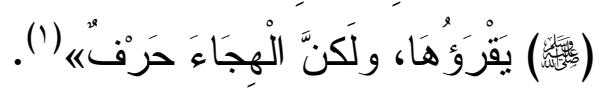

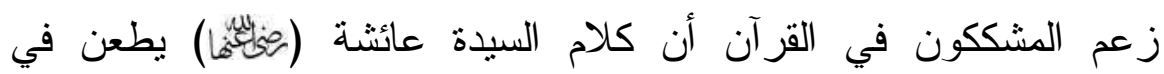

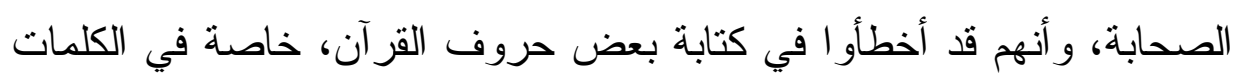

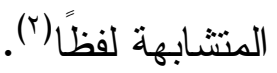

\section{دراسة الزيمم والمكم عليه أولاً: الحكم على الرواية من جهة الإسناد:}

لقد اعتمد الزاعمون في تنكيكهم على رواية الإمام أحمد في المسند، وهي

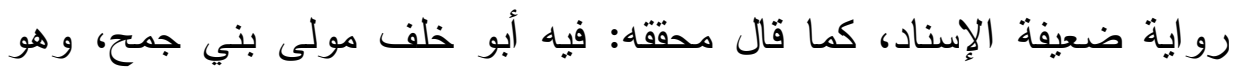

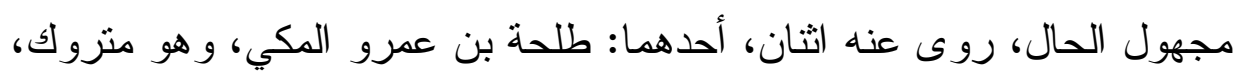

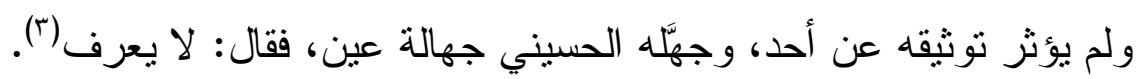

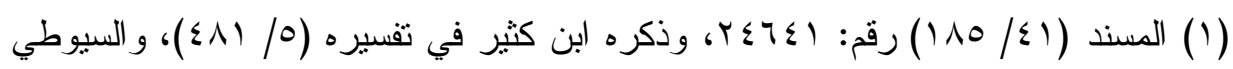

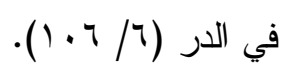

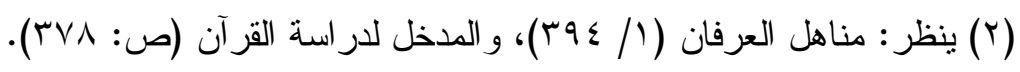

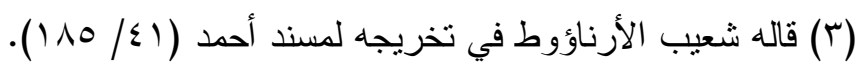


كما أن في الإسناد إسماعيل المكي، و هو إسماعيل بن مُسْم المكي ضعيف، قال ابن كثير : ضعِيف(')، وقال الهيثمي: رواه أحمد، وفيه إسماعيل المكي، وهو ضعيف(r). وأخرجه الطبري في تفسيره(r) من طريق طلحة بن عمرو، وطلحة

منزوك (£).

و أخرجه الحاكم من طريق يحيى بن راشد، عن خالا الحذاء، عن عبد الله

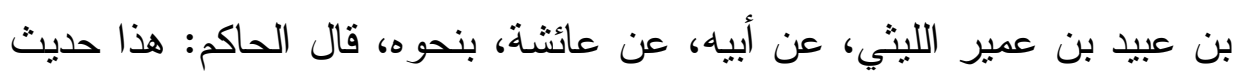

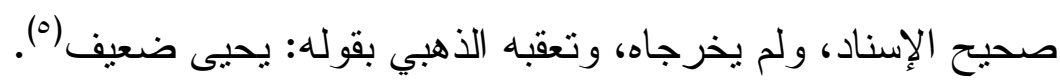
وعلى فرض صحة إسناد الرواية: فتحتمل ما يلي:

1- أن قول أمّ المؤمنين اولكن الهجاء حرفه تقصد بـه أنه مأخوذ من الحرف بمعنى القر اءة و اللغة، و المعنى أن هذه القر اعة المتو اترة التي رسم بها المصحف لغة ووجه من وجوه الأداء في القرآن الكريم. و لا يصح أن تكون كلمة "حرفه مأخوذة من التحريف الذي هو الخطأ، وإلا كان حديثًا معارضًا للمتو اتر ومعارض القاطع ساقط (`).

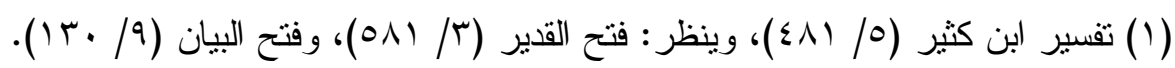

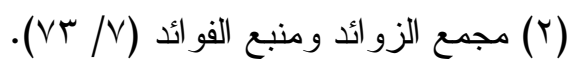

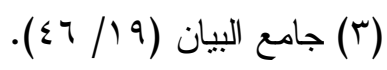

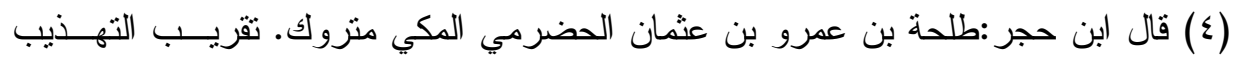

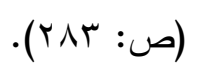

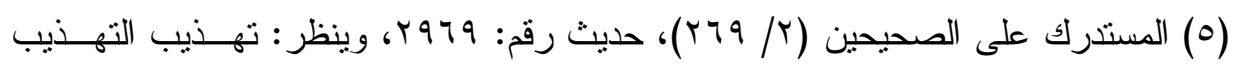

$$
\text { (r. }(r / 11)
$$

و استفدتُ هذا التخريج من حانشية مسند أحمد بتخريج شعيب الأناؤوط (1 (1) (1) (1).

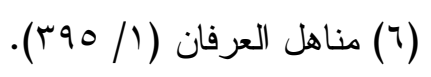


r- أن قول السيدة عائشة: 》أن رسول الله كان يقرؤهاه لا ينافي أن تكون القر اءة المتو اترة منزلة، وقر أ بها النبي، و لا سيّما وهي المتو اترة التي أجمع عليها القر اء السبعة (')

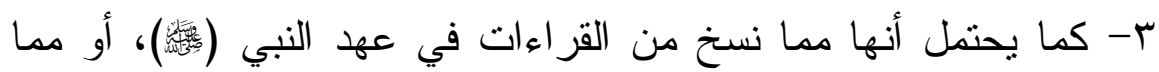
ترك عند جمع القر آن لعدم ثبوتها وتو اترها(؟). ع- ويحتمل أن يكون المر اد أخطئو ا في الاختيار ، وما هو الأَّلى لجمع لهم الناس عليه من الأحرف السبعة، لا أن الذي كتب خطأ خارج عن القر آن (ّ). 0- ورهاك من قال بالجمع بين القراعتين، فالمتواترة ظاهرها متعلق بالعبادة المالية، والأخرى تتعلق بالطاعة البدنية، على أن المتونزة يمكن أن يقال

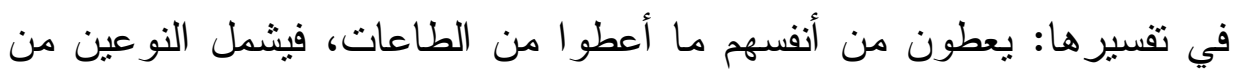

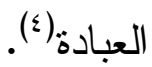

\section{ثانيًا: روّالرواية من جهة الهتن: هذه الرو اية مردودة متتا، للآتي:}

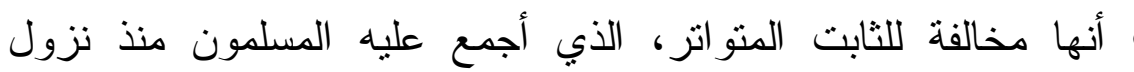
القرآن.كما أنها تطعن في كُّاب المصحف، وتصورهم بأنهم لا يستطيعون التفر قة بين حرف مدّ، و آخر . • كما أنها مردودة عقلاً، ومخالفة للواقع، فهي تنتافي تمامًا مع ما كان

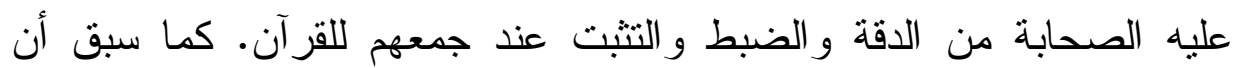
أثرت ' إلى ذلك فيما سبق.

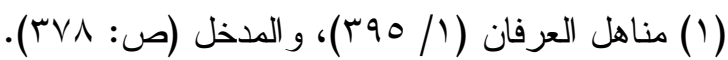

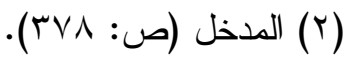

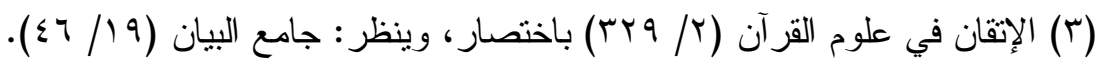

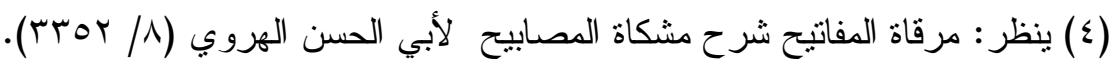




\section{ثالثا: موقفه الهفسرين منها:}

حكى الكثير من المفسرين هذه الرواية عند تفسير هذه الآية بايجاز ، دون

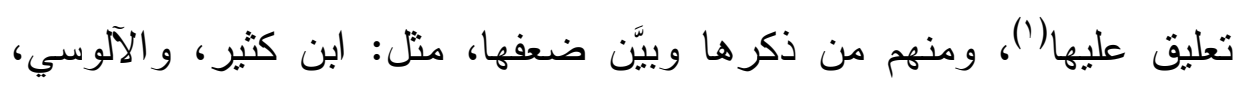
و الثوكاني

قال ابن كثير-بعد أن ذكرها-: فيها إسماعيل بن مسلم المكي، وهو

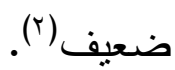

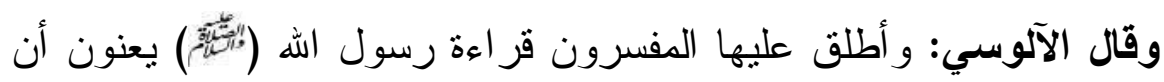

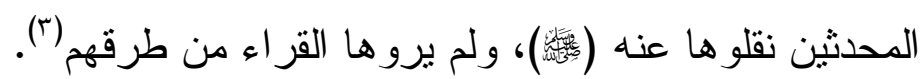
وقال الشوكاني: وفي إسناده إسماعيل بن علي، و هو ضعيف عاء (ء).

\section{رابعًا: مر|سة موضع الزعه:}

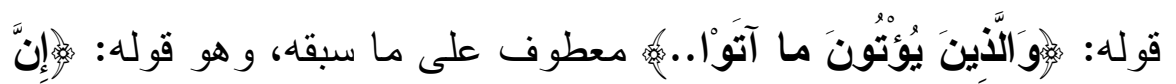

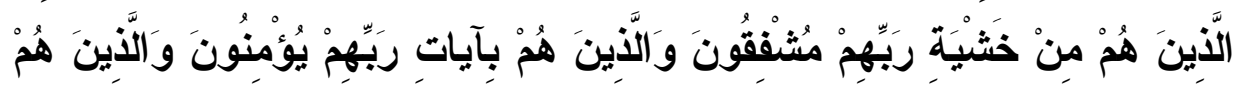

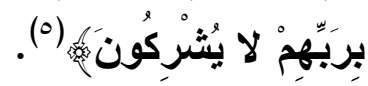

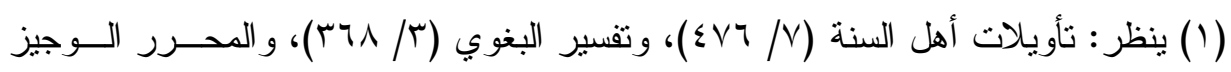

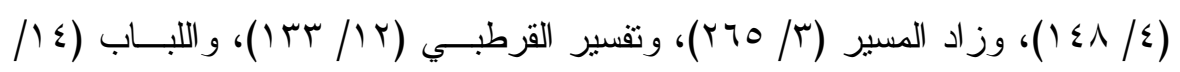

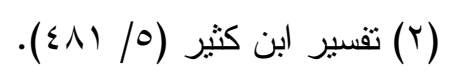

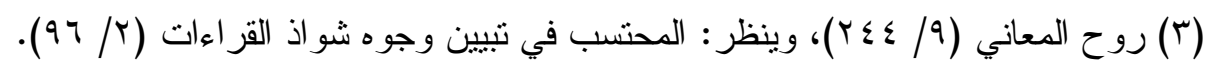

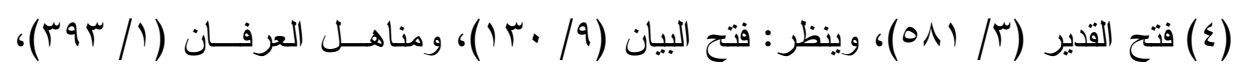

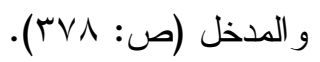

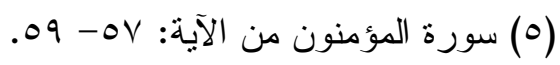


وهي أربع صفات يكون عليها الذين يسارعون في الخيرات، فهم (أولاً)

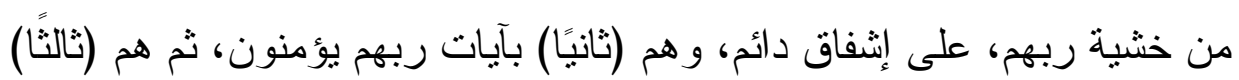

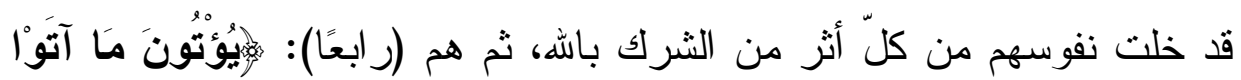

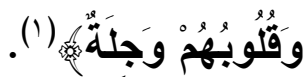

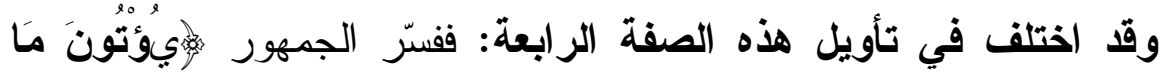

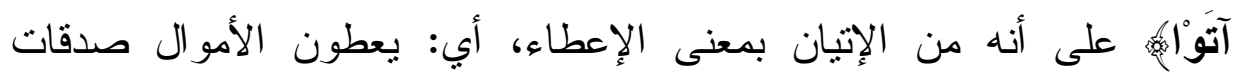
ونفقات في سبيل اله(؟).

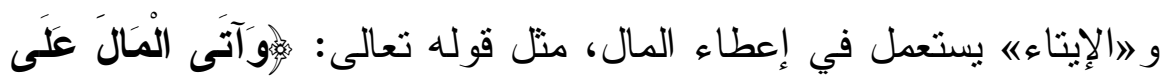

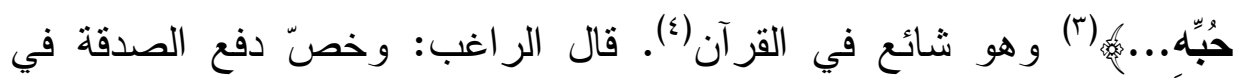
القر آن بالإيتاء (0).

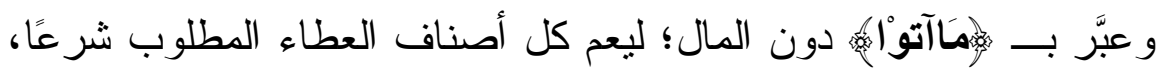

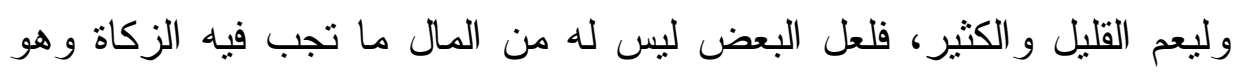

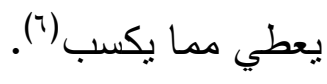
أمَّا عن سبب وجل قلوبهم: فهو خوفهم أن لا يقبل منهم هذا العطاء،

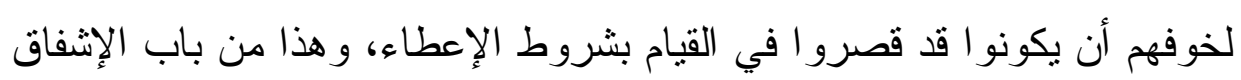

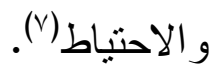

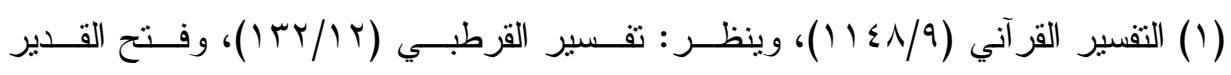
.$(O V N / T)$

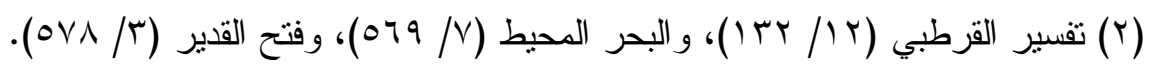

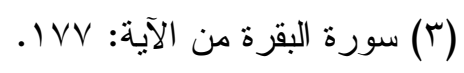

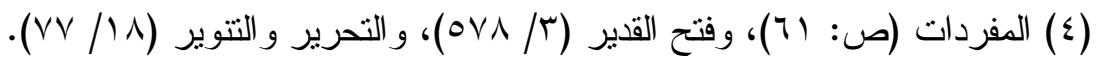

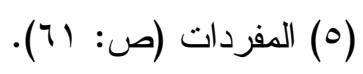

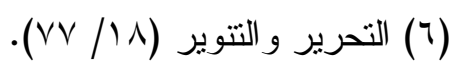

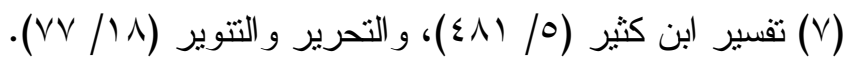




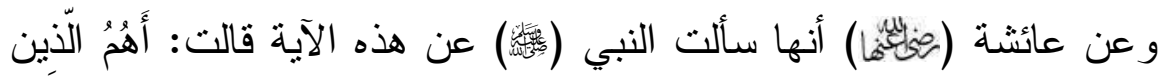

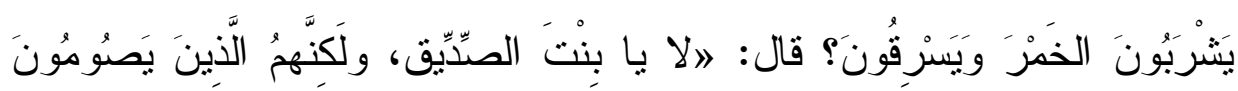

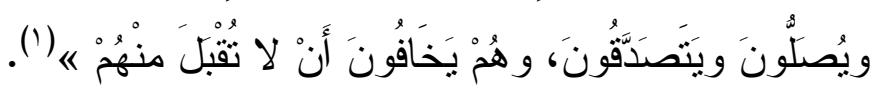
وهذا بمثابة التفسير للآية على قر اعة الجمهور (r). وأما قراعة: ايَاتُونَ ما أَتَوْاه من الإتيان، المروية عن عائشة هي -أيضًامروية عن ابن عباس وقتادة و الأعمش و الحسن و النخعي، وهي قر اعة شاذة(؟). قيل في معناها: و الذين يأتون الذنوب وهم على خوف وخشية دن لقاء ربهم. وقيل: يفعلون من العبادات ما فعلوه وقلوبهم وجلة. وقيل: في جميع الأعمال

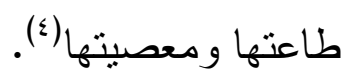
وما قرأ به الجمهور وفسروا به هو الصواب، بدليل ما ورد في الحديث السابق.

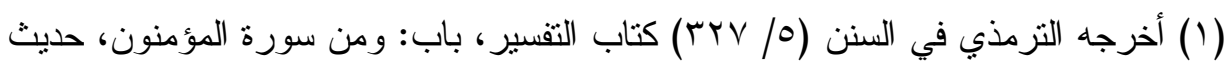

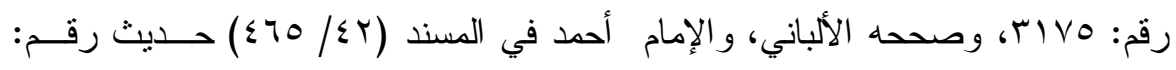

$$
\text { rov. } 0
$$

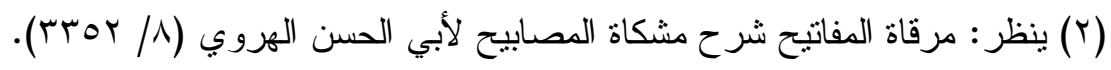

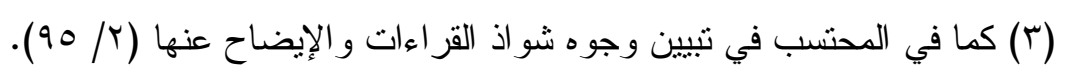

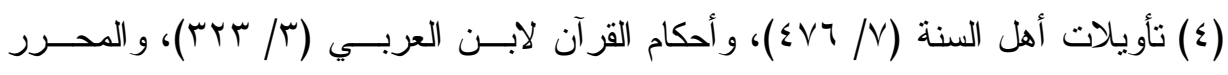

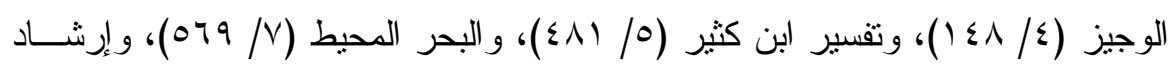

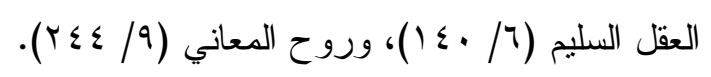




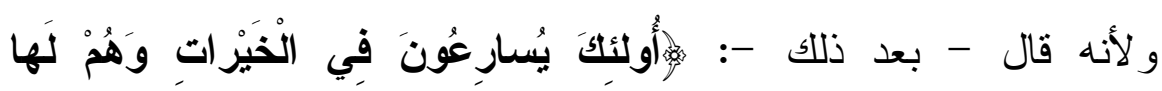

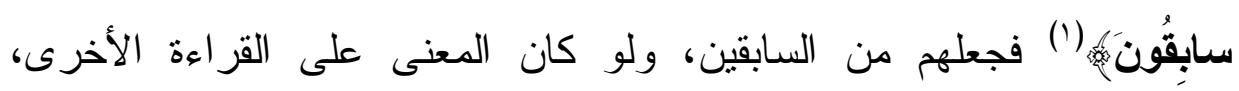
لأوشك أن لا يكونو ا من السابقين، بل من المقتصدين أو الدقتصرين (؟).

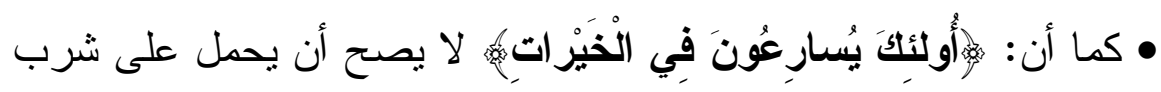
الخمر وسرقة المال، وسائر السيئاتها(").

$$
\begin{aligned}
& \text { (1) سورة المؤمنون من الآية: الجا. }
\end{aligned}
$$

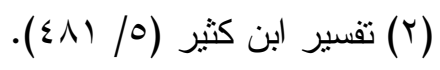

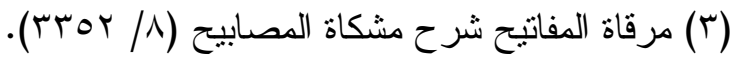




\section{المبحث|الثالث \\ ها ورد هول الزيادة أو النقص}

\section{الإطب الأول \\ ما ورد هول زيلادة هرف}

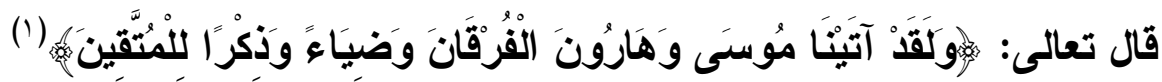

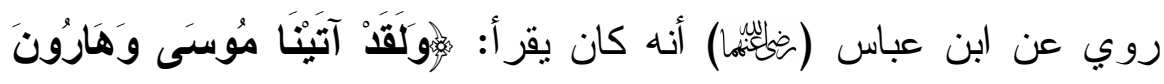

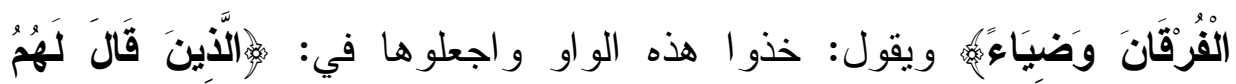

النَّاسن.... (r)

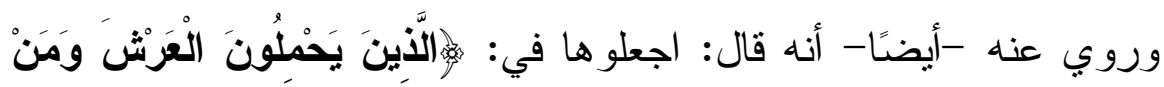

حَوْلَهُ...

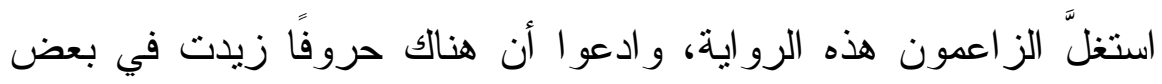

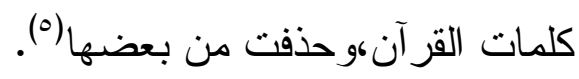

$$
\begin{aligned}
& \text { (1) سورة الأنبياء الآية: 1ــ. }
\end{aligned}
$$

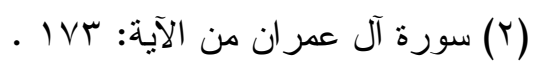

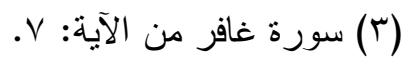

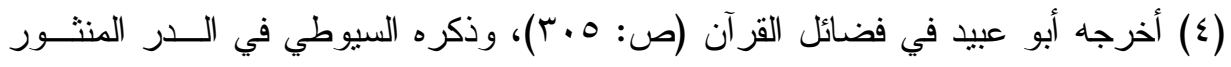

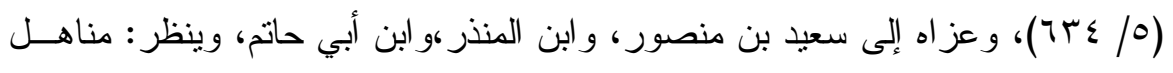

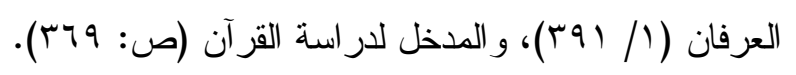

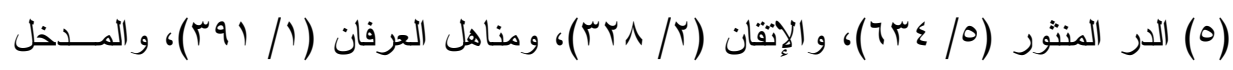

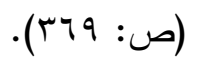




\section{دراسة الزتعم والمكم عليه}

\section{أولاً: الد|فع لهذ|الزعم:}

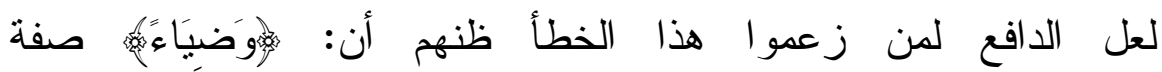

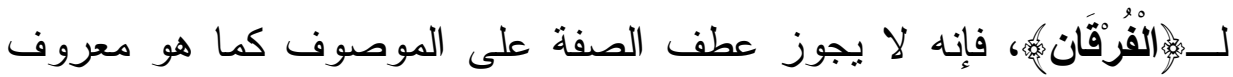
عند النحاة.

وهذا الادفع مردود: لأن حرف الواو هنا لم يعطف صفة على موصوف -

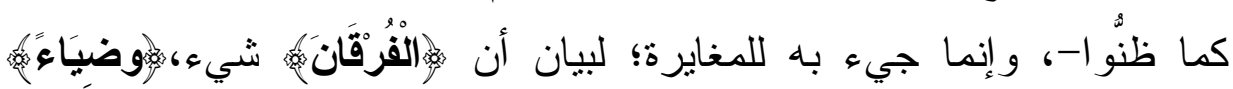
شيء آخر، ولو تركت لالتبس الأمر، وظنَّ أن الفرقان هو الضياء (افالبلاغة

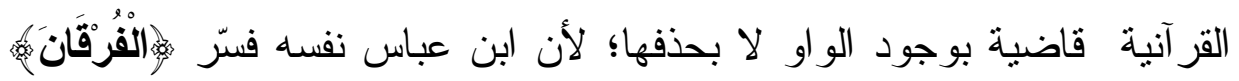
في الآية المذكورة بالنصر، و عليه يكون الضياء بمعنى التور اة أو الثريعة، فالمقام للواو لأجل هذا التغاير" (').

\section{ثانيًا: الحكم على الرواية من جهة الإسنام:}

أخرج هذه الرواية السيوطي في الدر المنثور(؟)، وعزاها:ها إلى ابن أبي

حاتم، و ابن المنذر، وسعيد بن منصور ، ولم أجدها عندهم.

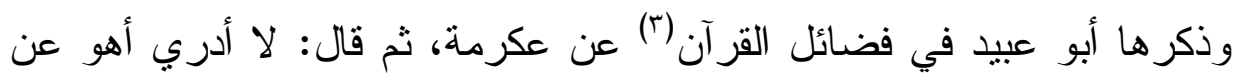

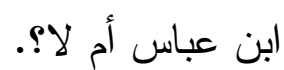

• كما لم يذكر ها أحد من المفسرين فيما اطلعت عليه.

وقد ردّها الزرقاني، فقال: هذه الرواية ضعيفة، لم تصحح عن ابن عباس(ع).

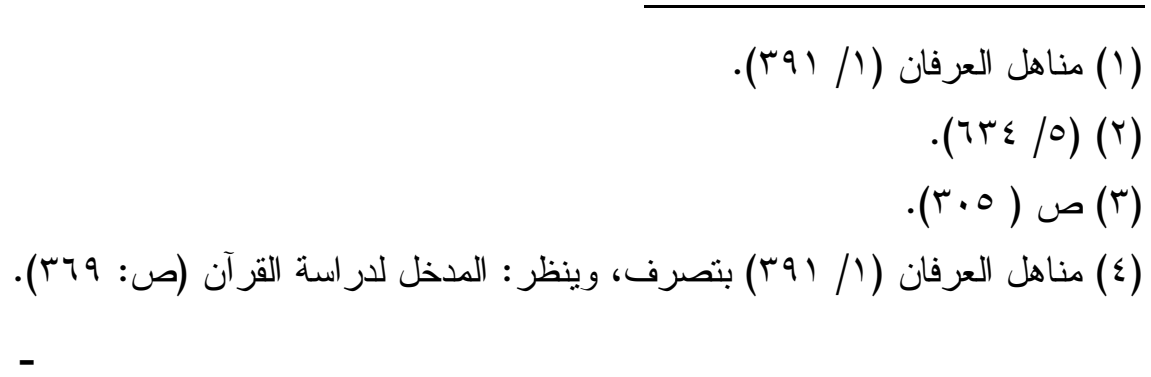


وعلى فرض صحة الإسناد: فهي رواية آحاد، و لا تقوى على معارضة المتو اتر بأي حال.

\section{ثالثًا: ردّها من جهة الهتن:}

هذه الرواية مردودة؛ لأنها تطعن في كتَاب الله، ونتشير إلى أن الكُّاب قد فاتهم أن يضعوا الو او في موضعها، فوضعوها خطأ في غير محلها، وكأنّ ابن عباس (خظلّمهم) هو الذي كان ير اجع القر آن ويصححه حتى وجد الواو ليست في موضعها، وكل هذا غريب وباطل،فأين كان الصحابة يوم أن كُتبت هذه الكلمة وجن خطأ؟ ومن هم الذين كان بحدثهم ابن عباس، ومتى هوب؟

\section{رابعًا: در|سة موضع الزعم:}

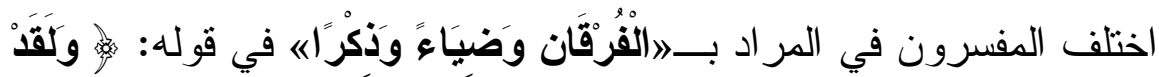

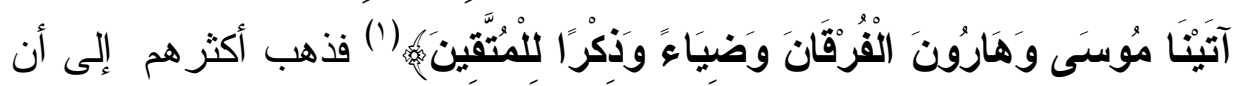

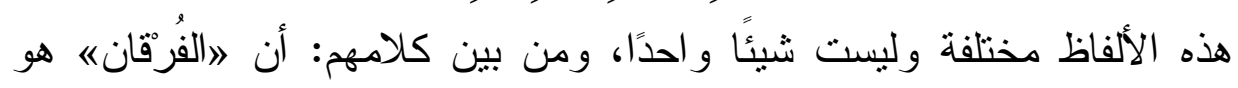

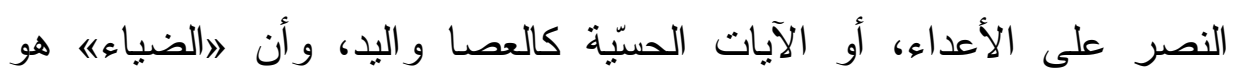
》التور اةه وكذلك 》الذِّرِ، فيكون معنى الآية: ولقد آتينا موسى وهرون

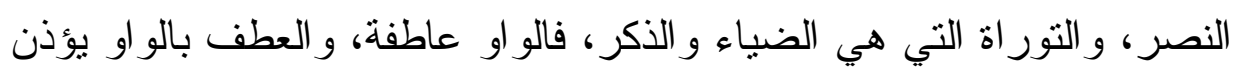

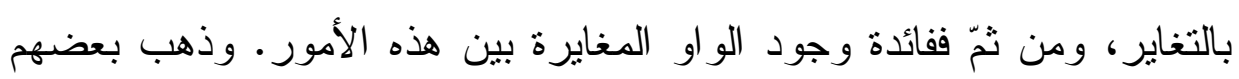

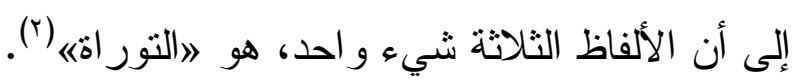

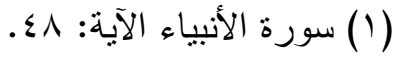

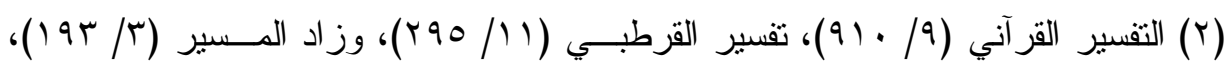

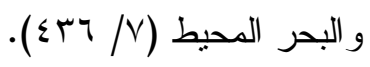




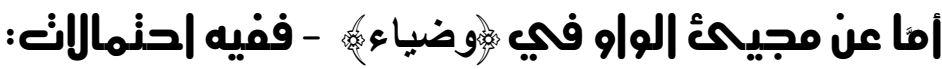

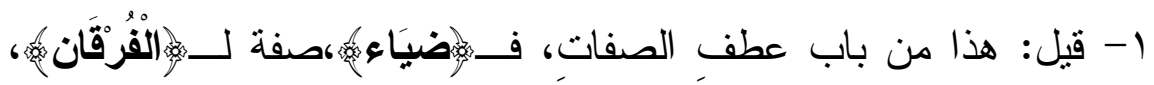

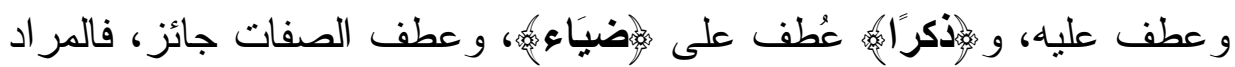
به شيءٌ واحد، أي: آنتيناه الجامع بين هذه الأشياء (').

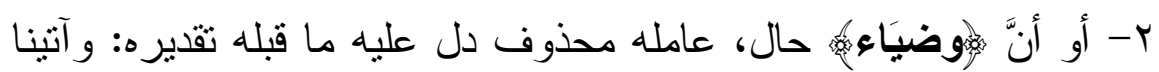
به ضياء (r) (r)

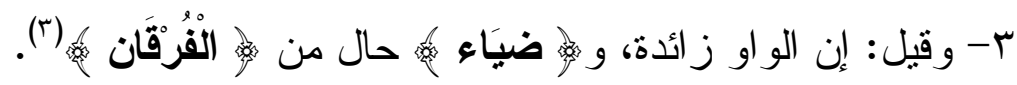

وأَرَى: أن هذا القول يجب ردّه، فالقول بالزيادة قول لا يليق بالقر آن (๕). ع- وزعم الفر اء أن حذف الواو و المجيء بها و احد، كما قال اله (هَّلَّ):

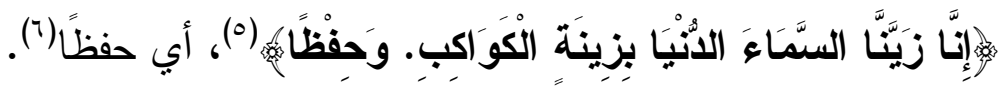

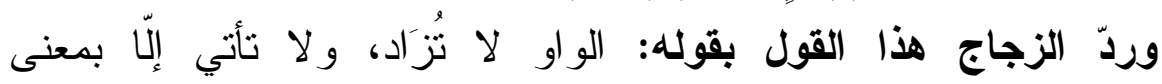

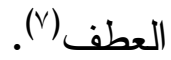

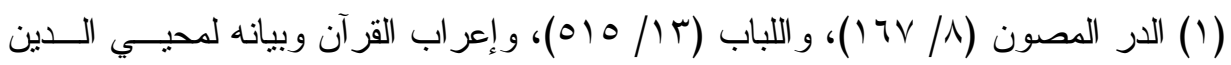

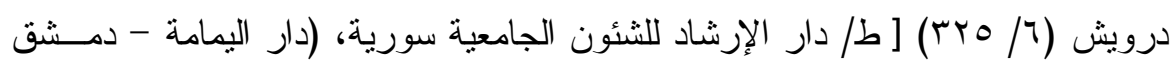

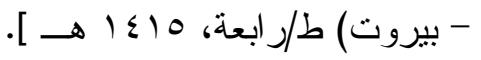

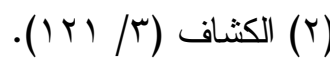

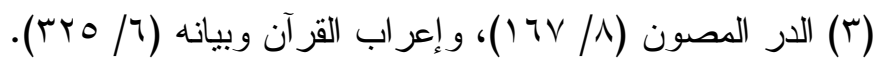

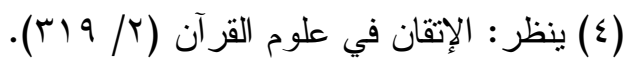

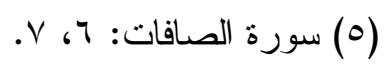

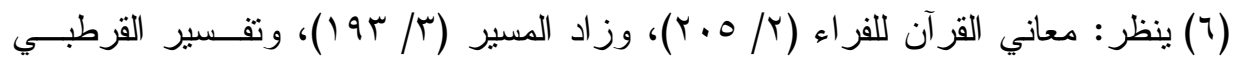

$$
\text { . ( } 90 / 11)
$$

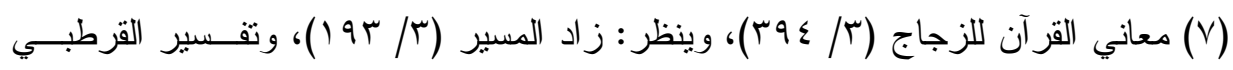

$$
\text { ( }(\text { r } 90 / 11)
$$


وقال الطبري - بعد أن ذكره - : إن ذلك وإن كان الكلام يحتمله.. فالو اجب أن يوجه معاني كلام الله إلى الأغلب الأشهر من وجوهها المعروفة عند العرب ما لم يكن بخلاف ذلك ما يجب التسليم له من حجة خبر أو عقل ('). وعلى كل حال: فهذه كلها احتمالات وإن كانت واردة إلا أنها غير مشهورة، و الراجح الرأي الأول، و أثنار إليه الطبري بقوله: وهذا القول الذي ولي قاله ابن زيد في ذلك أثبه بظاهر التتزيل، وذلك لدخول الواو في الضياء، ولو

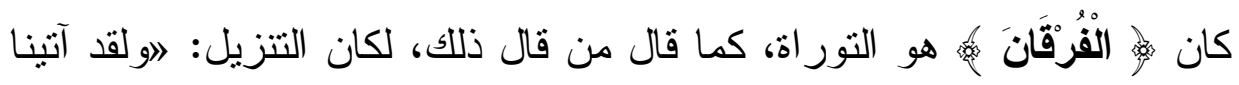
موسى وهارون الفرقان ضياء《 لأن الضياء الذي آتى الله موسى وهارون هو

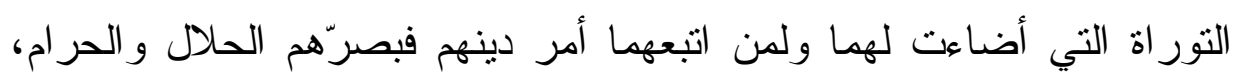
ولم يقصد بذلك في هذا الموضع ضياء الإبصار ، وفي دخول الو او في ذلك دليل

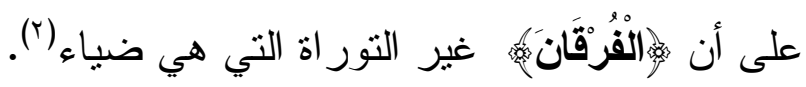
والخلاصة: فذكر الواو في الآية هو الذي تقضي به البلاغة الفائقة، لا

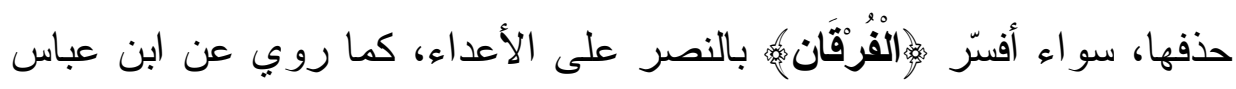

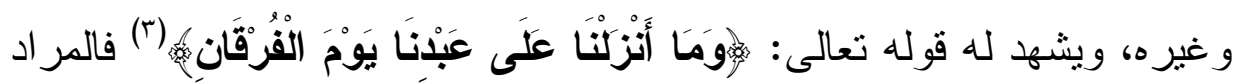
باه يوم بدر - أو فُسّر بالتور اة.

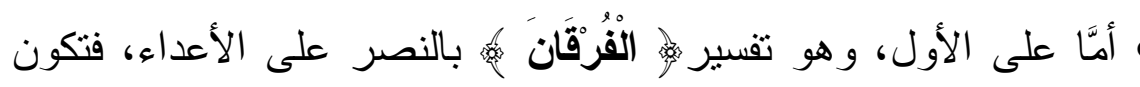
الو او لازمة البتة لتغاير المعطوف و المعطوف عليه، ويكون المراد بالضياء التور اة أو الثريعة.

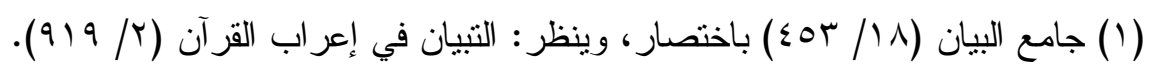

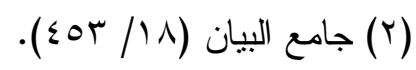

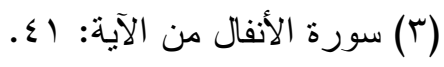




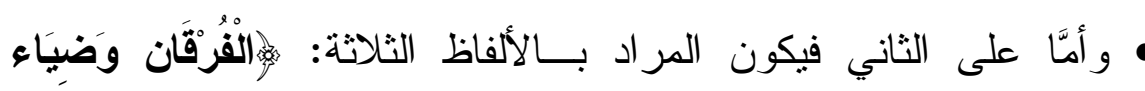
وذَكِرَا الطريق للسالكين، وهي ذكر لما فيها من التذكير و المو اعظهولمجيء الواو سر بلاغي وهو الإثارة إلى بلوغها درجة عالية في كونها ضياء، حتى أضحت

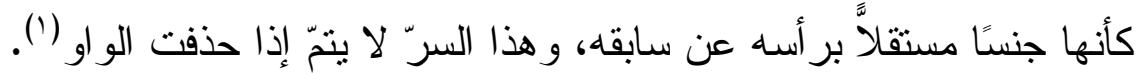

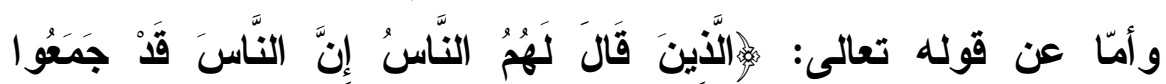
لكَمْ..... (ז) ومجيئه من غير عطف؛ فلوجود ما يدعوا إلى الفصل؛ لأنه يجوز

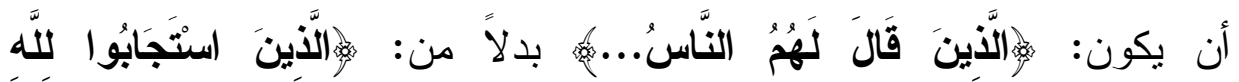

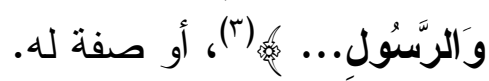

و إنما جيء بإعادة الموصول دون أن تعطف الصلة على الصلة، اهتمامًا بثأن هذه الصلة الثانية حتى لا تكون كجزء صلة، ويجوز أن يكون ابتداء كلام

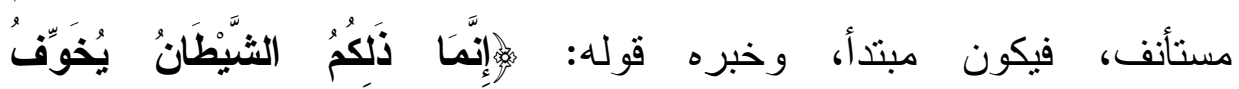

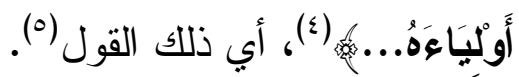
وأمَّا عن مجيئ قوله:

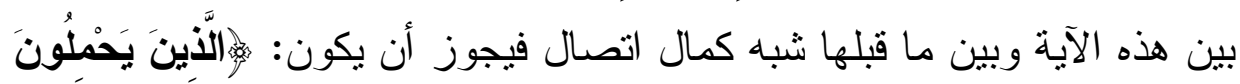

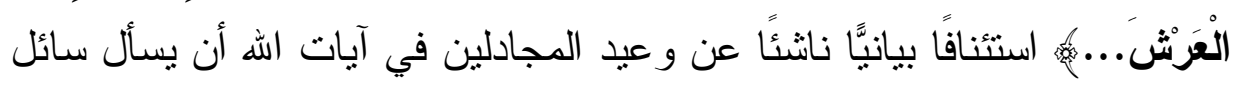

$$
\begin{aligned}
& \text { (1) المدخل لدر اسة القرآن (ص: • •YV) بتصرف. }
\end{aligned}
$$

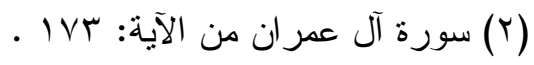

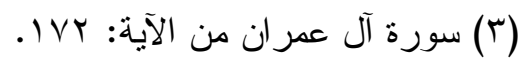

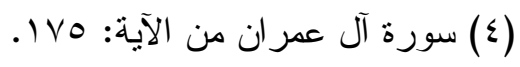

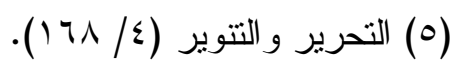

$$
\begin{aligned}
& \text { (ך) سورة غافر من الآية: v. }
\end{aligned}
$$


عن حال الذين لا يجادلون في آيات الله، فُصسلت الآية الثانية عن الأولى كما يفصل الجواب عن السؤال، لما بينهما من شبه كمال الاتصال، وهو من مو اضع الفصل بين الجمل،كما هو معروف عند البلاغيين (').

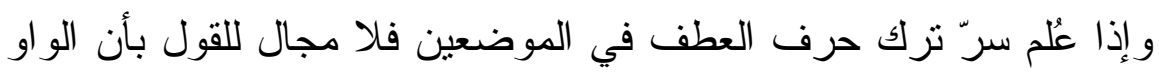
أسقطت من هاتين الآيتين كما ورد في الزعم. و الله أعلم.

\section{الامثب الثاني

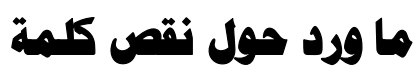

قال تعالى

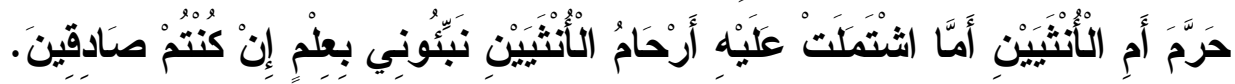

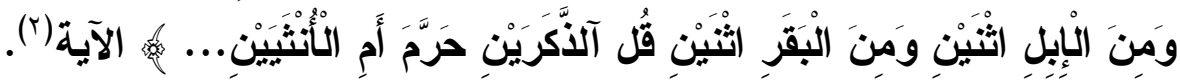

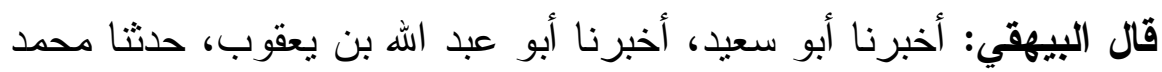
بن نصر ، حدثنا الحسن بن علي الحلواني، حدثنا يحيى بن آدم، حدثنا عبد

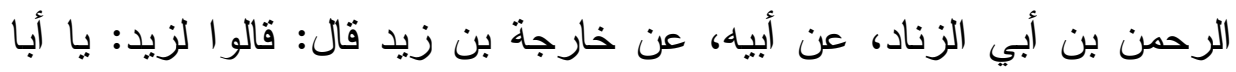

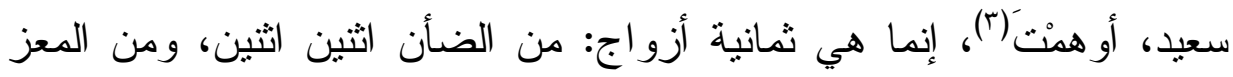

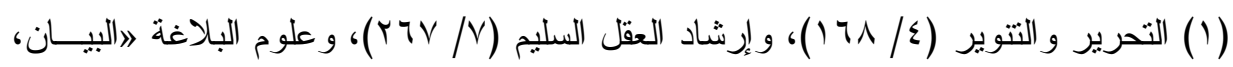

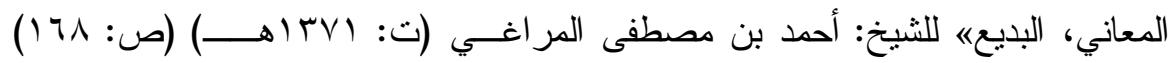

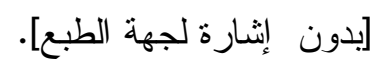

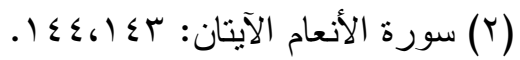

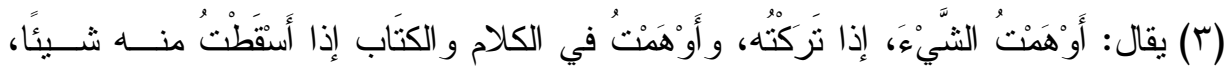

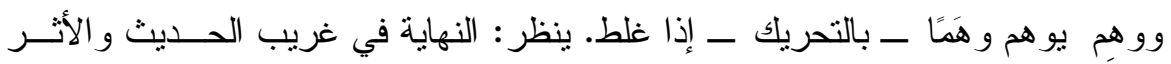
(rTr/0) 
اثثين اثثين، ومن الإبل اثثين اثثين، ومن البقر اثثين اثثين، فقال: 》لا، إن اله

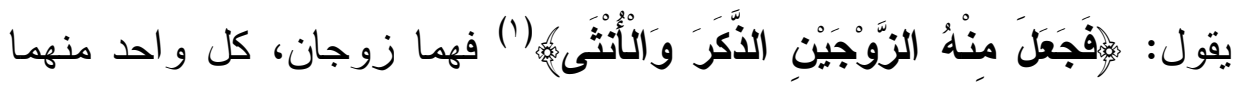

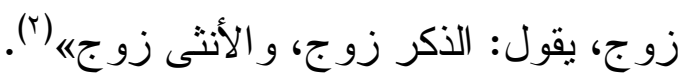

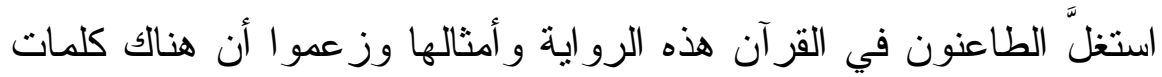

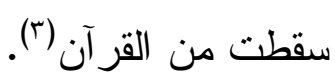

\section{دراسة الزمعم والمكم عليه}

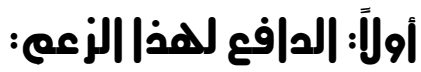

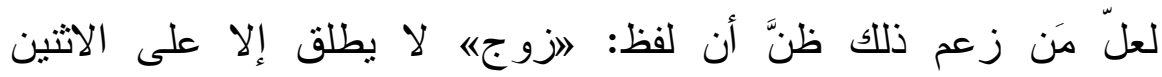

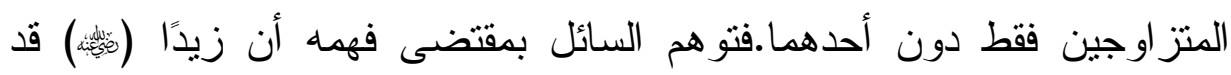

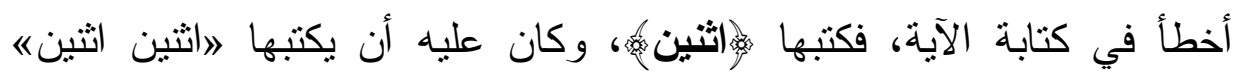

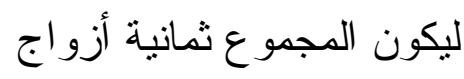

وهذا الظن مردود: لأن لفظ ازوجيهكما يطلق على الاثثين المتزاوجين،

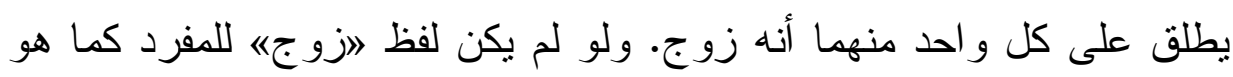
للمثنى لماصح قوله:

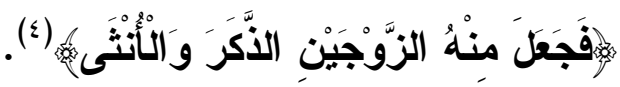

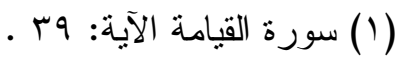

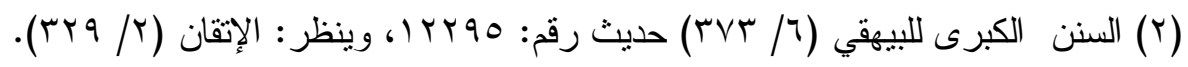

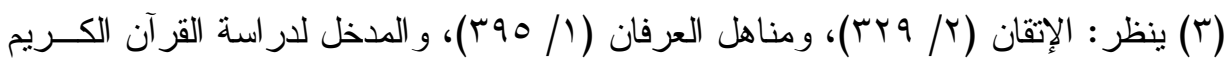

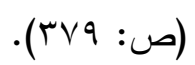

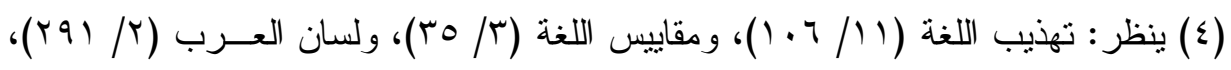
وبيان الإسلام للرد على شبهات حول الإسلام. [ شبكة الإنترنت]. 
فالأزواج جمع زوج، والزوج يطلق على كل فرد يقابله فرد آخر، ويقال

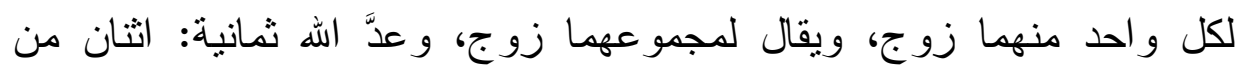

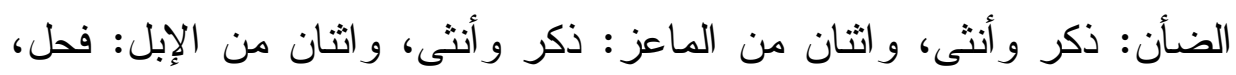

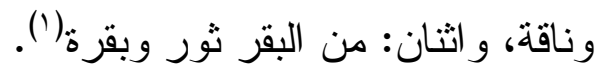
ولغة العرب تؤيد ما ذهب إليه زيد (ئبية)، ففي لسان العرب:

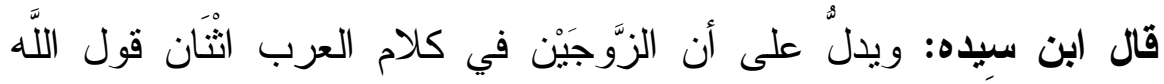

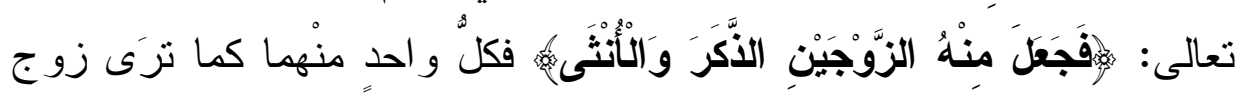

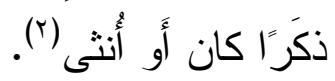

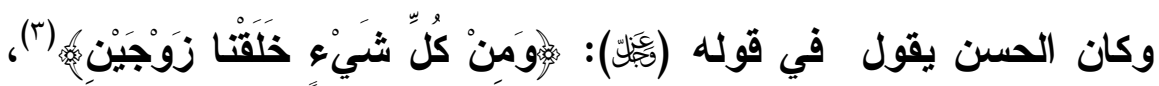

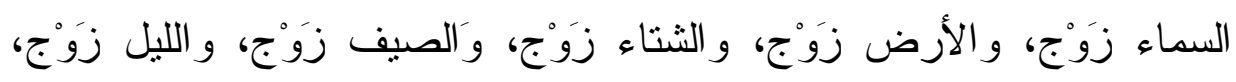

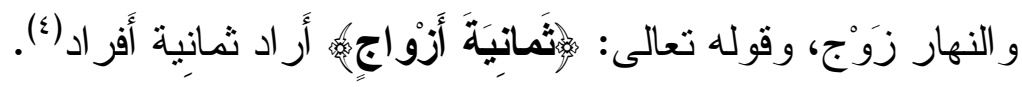

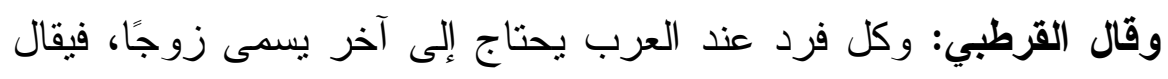

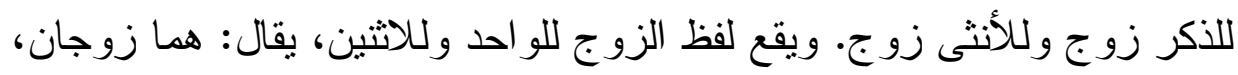

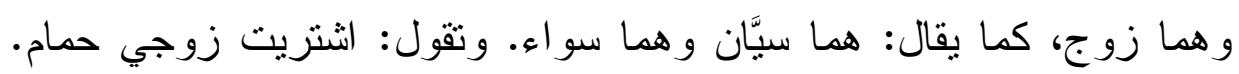

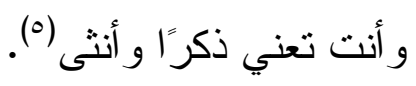

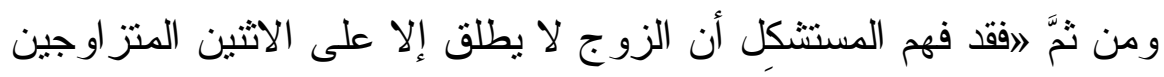

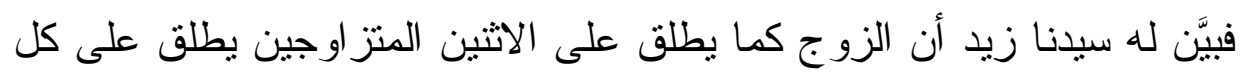

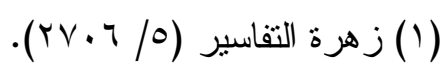

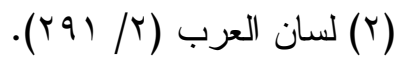

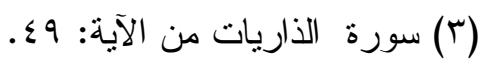

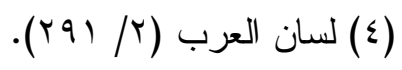

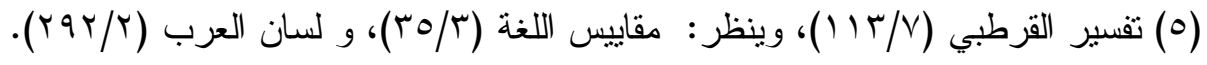


و احد منهما أنه زوج، واستدل له بالقرآن الذي هو الحجة البالغة،وقد اقتتع السائل وسكت، و الصحابة الذين كتبو ا القرآن، و الذين حملوه، وبلغوه لمن بعدهم كانو ا الغاية في الضبط، و التثبت و الأمانة الفائقة، وفي الذروة منهم زيد بن

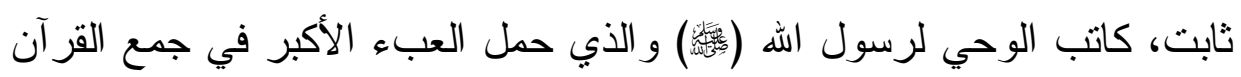
في عهد الصديق، وعهد عثمانه (').

\section{ثانيًا: الحكم على الرواية من جهة الإسناد:}

هذه الرواية لم يخرجها أحد من أهل الحديث غير البيهقي - فيما اطلعتُ عليه- ولم أقف على حكمٍ لإسنادها، ولم أجد من المفسرين من نقلها في تقسيره، سوى السيوطي الذي ذكرها في الاتقان(؟)، و الآلوسي الذي أثنار إلى هن وضعها في تقسيره(r).

و إسناد البيهقي هذا ضعيف، فيه عبد الرحمن بن أبي الزناد: قال يحيى بن

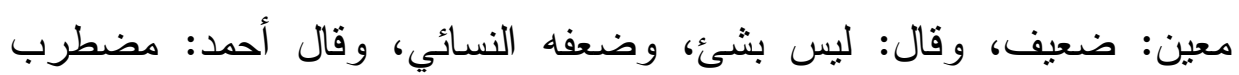

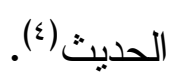

وقال ابن حجر : صدوق تغير حفظه لما قدم بغداد(0).

(1) المدخل لدراسة القرآن (ص: بV9)، وبيان الإسلام للرد على شبهات حـول الإســلام [نبكة الإنترنت].

$$
\begin{aligned}
& \text {. }(r q / r)(r)
\end{aligned}
$$

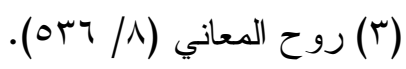

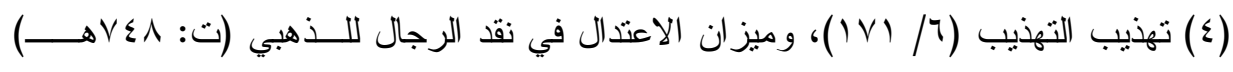

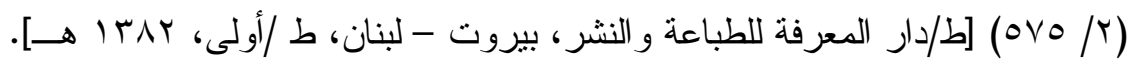

$$
\text { (0) تقريب التهذيب (ص: • ؟r). }
$$


وعلى فرض صحة إسنادها: فهي رواية آحاد، ولا ترقي لمعارضة المتو اتر بأي حال. كما أن الو اهم هو السائل، وليس زيد بن ثابت، وقد قام زيد بن ثابت بالرد عليه، و استدلَّل له بالقر آن، وقد اقتنع السائل، وسكت (').

\section{ثالثا: روها من جهة الهتن:}

يكفي في ردّ هذه الرواية أنها مخالفة للمتواتر الثابت القطعي، ومخالفة لإجماع الأمة، وأي رواية تخالف المتو اتر وتطعن في القرآن فهي مردودة لا لانها شك في ذلك 》افالذي يجنح إليه تضعيف جميع ما ورد مما فيه طعن بالمتو اتر ، و إن صححه مَن صححه، و الطعن في الرواة أهون بكثثر من الطعن بالأئمة الذين تلقو القرآن العظيم الذي وصل إلينا بالتو اتر، ولم يألو إنهاً في إنقانه

وحفظهه (r).

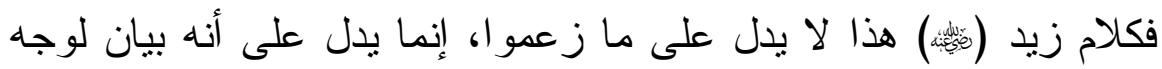

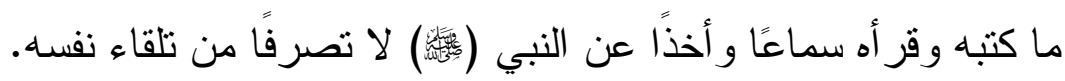
وكيف يتصور هذا من الصحابة في القرآن وهم مضرب الأمثنال في كمال ضبطهم وتثبتهم في الكتاب، لا سيّما زيد بن ثابت المعروف بحفظه،وأمانته

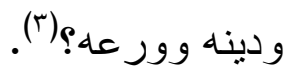

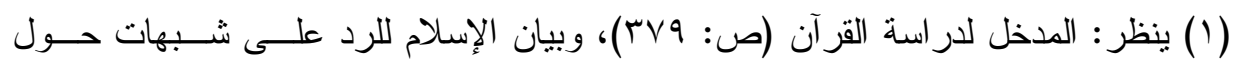

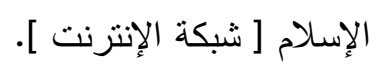

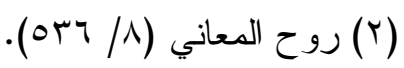

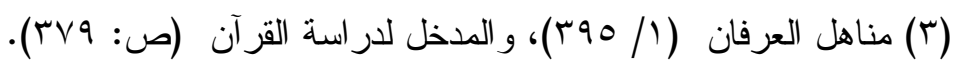




\section{المبحث الرابع}

\section{ها ورد حول خطأ الكاتب هن الناحية النموية(')}

استغلَّ الز اعمون و الطاعنون في القرآن بعض روايات نشير إلى وجود أخطاء نحوية في القرآن، ومنها ما أخرجه الطبري قال: حدثا ابن حميد قال

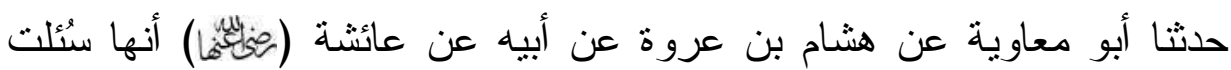

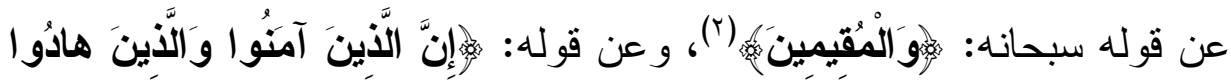

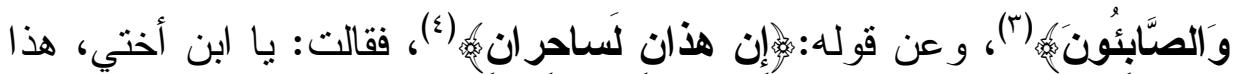

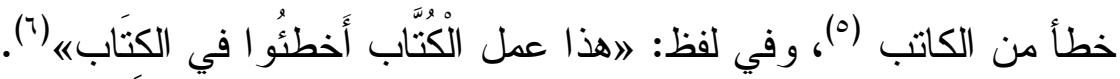

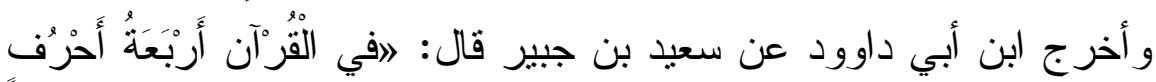

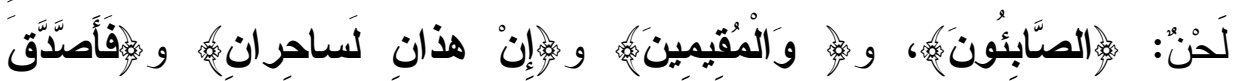

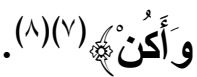

(1) هناك مز اعم وشبهات تحوم حول إعراب القر آن غير هذه، ولكن لا تــــخل معنـــا فـي موضوع البحث حسبما قيدته في خطة البحث سابقًا.

(Y) سورة النساء من الآية: بال ا.

(T) سورة المائدة من الآية: 79 .

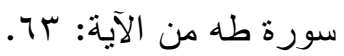

(0) التفسير من سنن سعيد بن منصور ( \&/0.V (1))، وذكره ابن أبي داود في المــصاحف

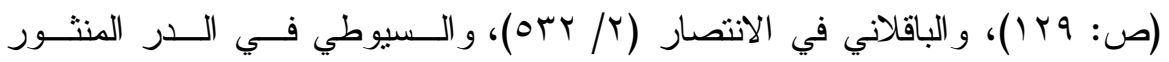
$\cdot(v \leq 0 / T)$

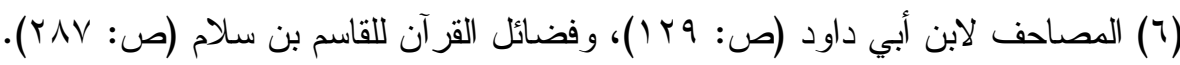
(V)

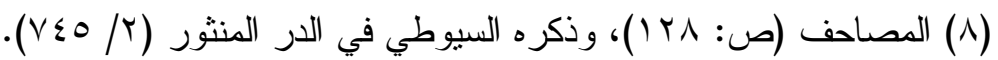




\section{دراسة الزعم والمكم عاليه}

\section{أولاً : الد|فع لهذ|الزعم:}

الأي دفع هؤلاء إلى ترديد هذا الزعم: جهلهم بلغة العربهوقواعدها

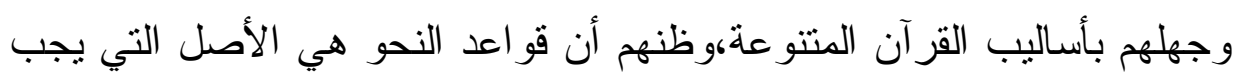
أن يُكتب عليها القر آن، و اعتمادهم على بعض ما قر أوه من رو ايات شاذّة، ظنّو ال أن وجودها في بعض الكتب دليل على صحتها، وأن سكوت بعض العلماء عليها دليل على تصديقهم لها.

اوكل هذا كلام باطل: فالقرآن فوق النحو، إذ النحو يستقى منه، وهو لا

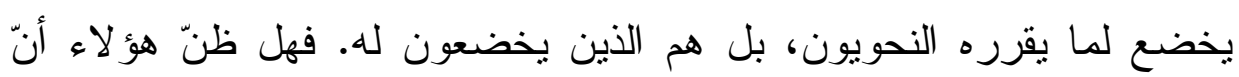

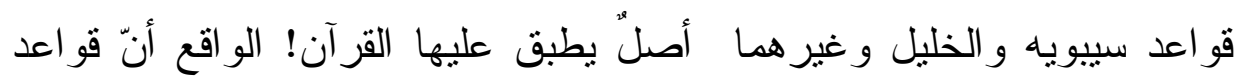
الخليل وسييويه وغيرهما مِنْ و اضعي العلوم العربيّة إنَّما تكون صحيحة إذا إنا و افقت القرآن الكريم، أمّا إذا خالفته في شيء لا يمكن تأويله، فإنّه يكون خطاً بلا نز اعه (')

• كما أن العرب الذين نزل فيهم القرآن كانو ا أفصح الناس، ولم يستشكل

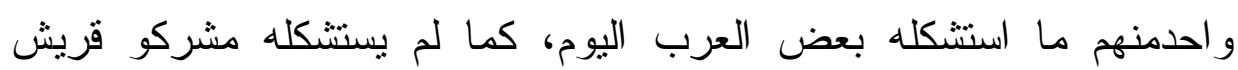

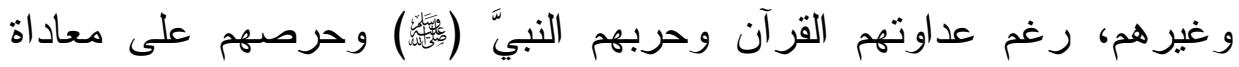

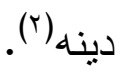

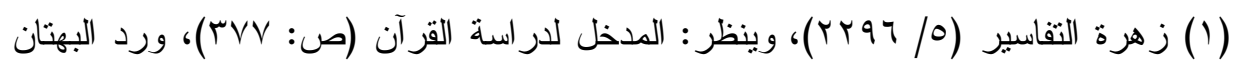

$$
\text { (ص: }
$$

(Y) تنزيه القرآن الكريم عن دعاوى المبطلين للثيخ/منقذ الـسقار (ص: • (Y) بتـصرف.

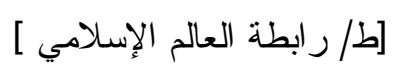


• لقد نسى هؤلاء أن الذين وضعو ا قواعد النحو هم أهل الإسلام وحفظة

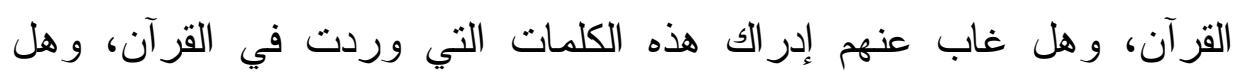
رضوا لأنفسهم أن يضعوا قو اعد نحوية تخالف ما ورد في كتاب ربهم وهم أحرص الناس عليه.. و إذا جوزنا النسيان على واحد منهم، فهل يجوز النسيان على الجميع؟

\section{ثانيًا: الحكم علىه الرواية من جهة الإسناد:}

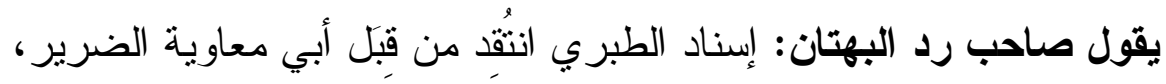
وهشام بن عروة: أمّا أبو معاوية الضرير، فهو محمد بن خازم الكوفيّ، قال

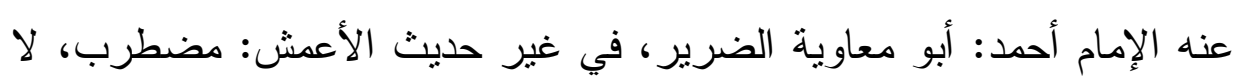
يحفظها حفظًا جيّدًا ('). وقال الحافظ ابن حجر: قال أبو داود قلت لأحمد كيف حديث أبي معاوية عن هشام بن عروة قال فيها أحاديث مضطربة يرفع منها أحاديث إلى دئ

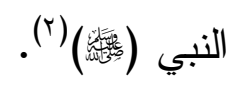

وهنالك مَن ذهب إلى أن الخطأ من قبِّل هشام بن عروة فقال: لاوليس

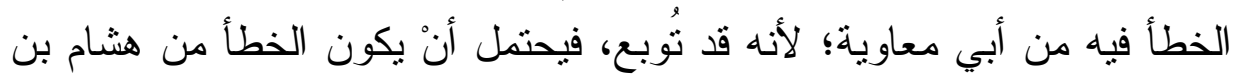

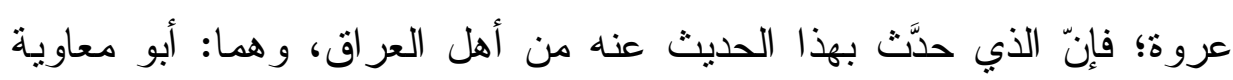
هنا، و عليّ بن مُنهر، وكلاهما كوفي، ورواية العر اقيين عن هشام بن عروة

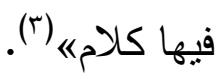

$$
\begin{aligned}
& \text { (1) رد البهتان (ص: 9؛)، وينظر : تهذيب التهذيب (9/ ^ـ (1). }
\end{aligned}
$$

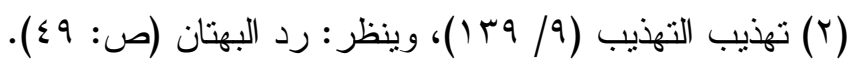

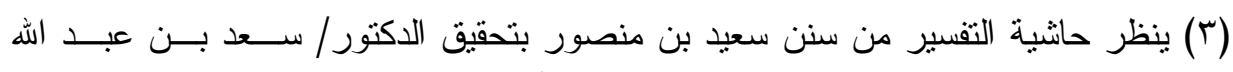

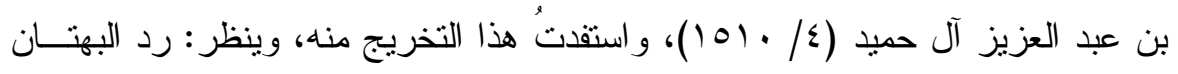

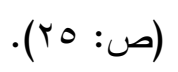


قال أبو حيان: وذُكر عن عائشة و أَبَان بن عثمان: إنَّ كَتْبَهَا بالباء من خطأ

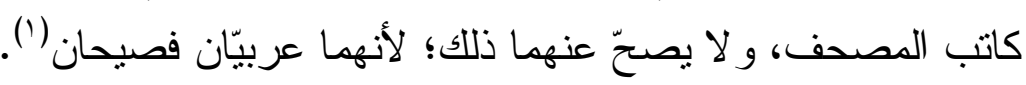

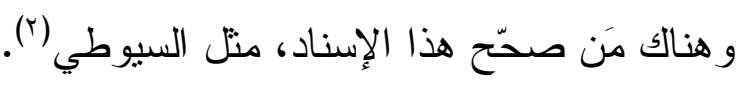

\section{وعلى فرض صحة إسنادها:}

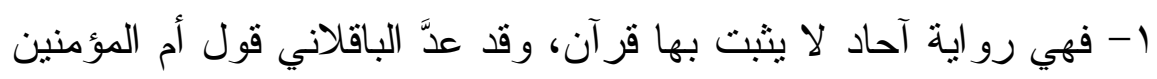

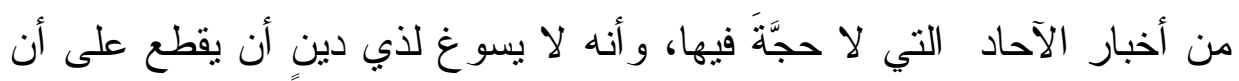
عائشة لحَّت الصنَّابة وخطأت الكَّبة (؟).

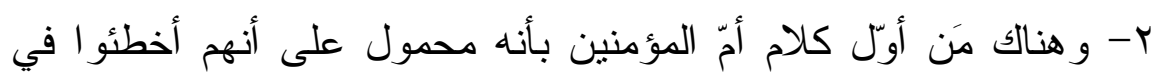

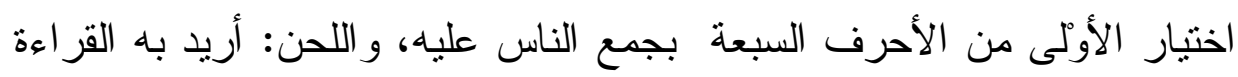

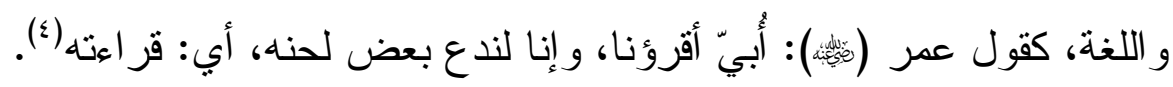

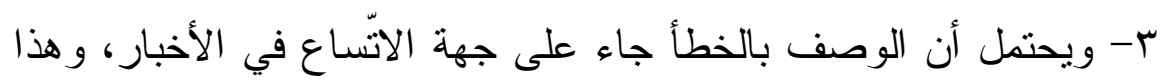

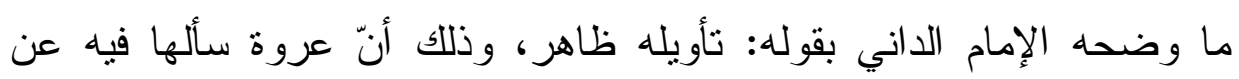

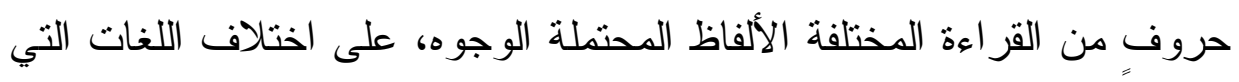

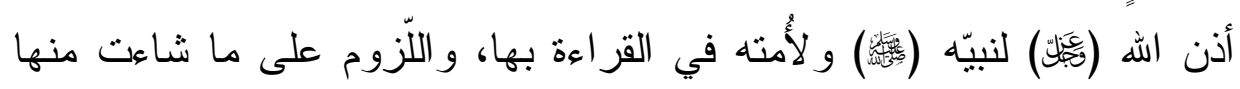

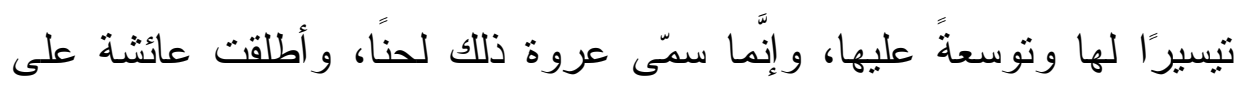

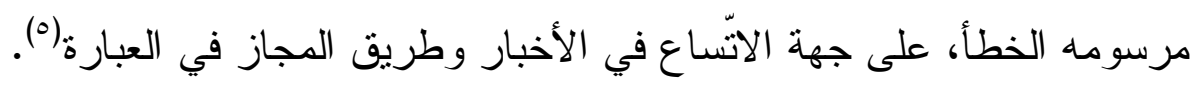

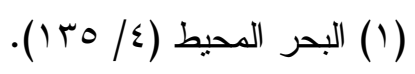

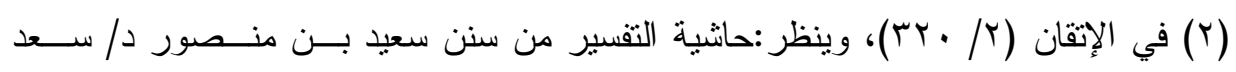

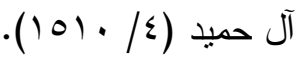

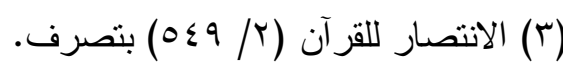

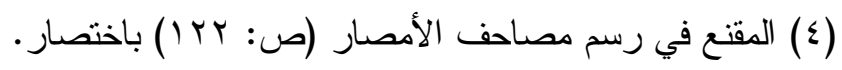

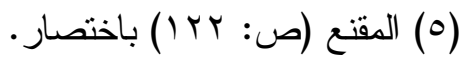


وما روي عن سعبد بن جيبر، فعلى فرض صحته: فهو خبر آحاد، و لا يقوى على معارضة الثابت. كما أن قول التابعي ليس بحجة، لا سيما في مثل هذه المسائل.

أقول: ويحتمل أن يكون المقصود بقول ابن جبير : "أَرَبْعَةُ أَحْرُفٍ لَحْنهُ،

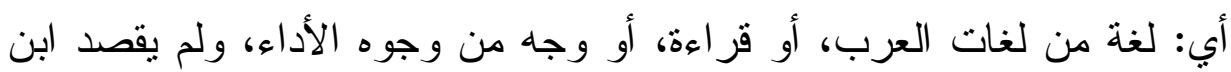
جبير اللحن بمعنى الخطأ، فمن معاني اللحن في اللغة: القر اعة، و اللغة - كما أنشار إلى ذلك الباقلاني ('). فلعلّ ابن جبير - إن صحّ ذلك عنه - أر اد أن في القرآن كلمات فيها من لغات العرب. وعلى كل:ٍ فهاتان الروايتان مهما يكن سندهما صحيحًا فإنهما مخالفتان للمتو اتر القاطع ومعارض القاطع ساقط مردود، فلا يلتفت إليهما ولا يعمل

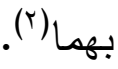

\section{ثالثا: رد الرواية من جهة المتن:}

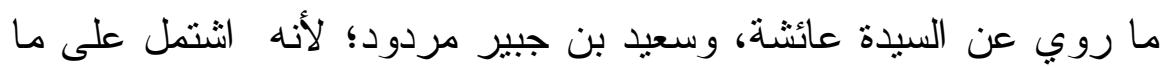
بطعن في القر آن، وما ثبت بالتو اتر .

• كما أنه من المحال أن يكون عثمان بن عفان والصحابة قد نركو ا في القر آن شيئًا فاسدًا فيأتي مَن بعدهم وهم أقرب إلى العُجمة فيكتشفونه (َ).

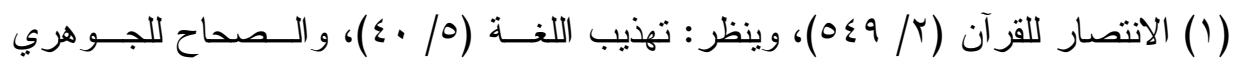

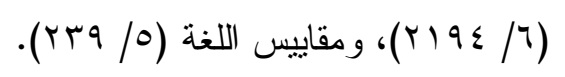

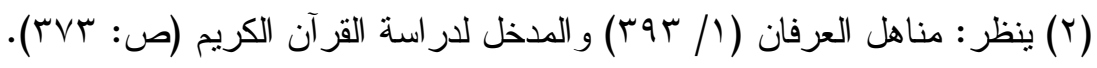

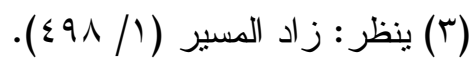




\section{رابعًا: رد الرواية من جهة|العقل:}

1- هذه الرواية مردودة عقلاً: فكيف يغيب عن الصحابة منل هذا؟ وهم أهل الفصاحة و المعرفة بوجوه العربية وضروب الردودة الخطاب،و اللغة لغتهم، و أُنزل

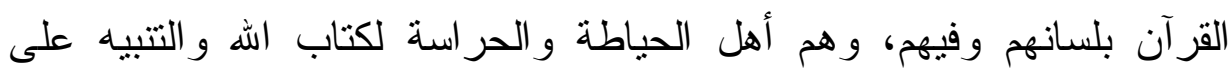
الواجب له وفيه، وما يجب أن نعتقد في صحيح ما ثبت فيه، و وغلط من أدخل فيه ما لبس منه (') ץ- ثم هل يعقل أن السيدة عائشة مع جليل قدرها ومعرفتها بلغة قومها أن

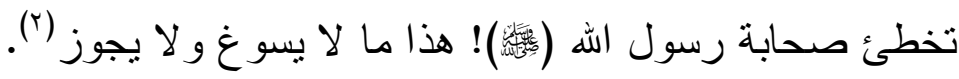

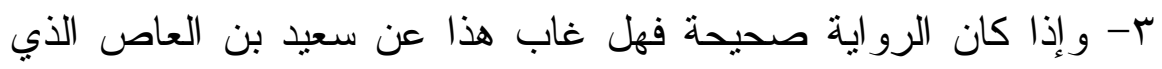

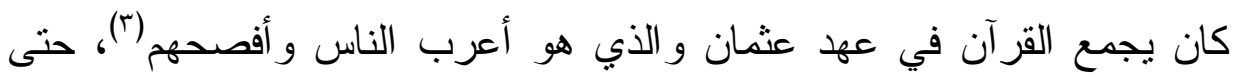

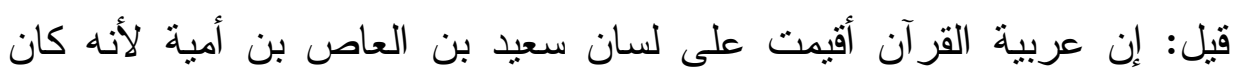

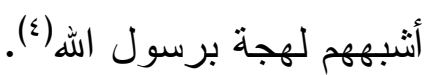
ع- وهل السيدة عائشة هي التي اكتثفت هذا وحدها؟ و إذا كانت قد لد اكتثفت هذا وحكمت عليه بأنه من خطأ الكاتب - فلماذا لم تعرض الأمر على العى

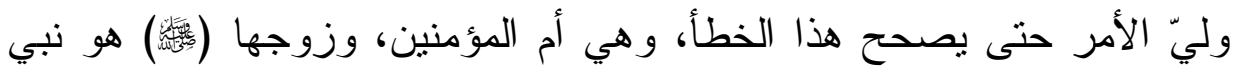

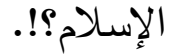

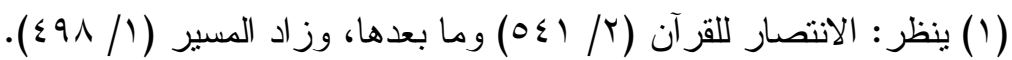

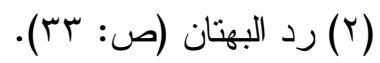

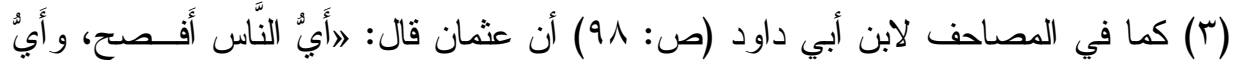

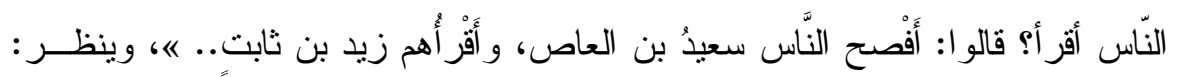

$$
\begin{aligned}
& \text { فتح الباري (9/9/9) (19). } \\
& \text { (£) المصاحف لابن أبي داود (ص: ؟ +1)، وفتح الباري (9/9 19). }
\end{aligned}
$$




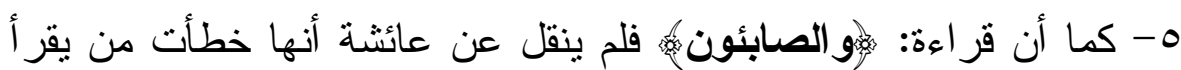
بها، ولم ينقل أنها كانت تقر أ بالياء دون الواو، فلا يعقل أن تكون خطأت من كتب بالو او (') - (1)

وقد علَّق الإمام الطبري على ذلك فقال: لو كان ذلك خطأ من جهة الخطّة

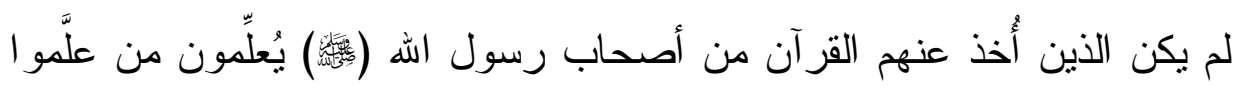
ذللك من المسلمين على وجه اللحن، و لأصلحوه بألسنتهم، ولقَّوه الأمة تعليمًا

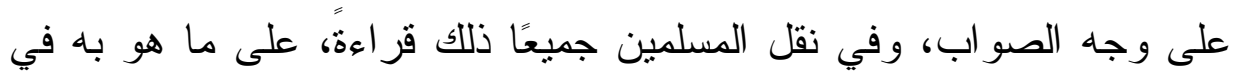

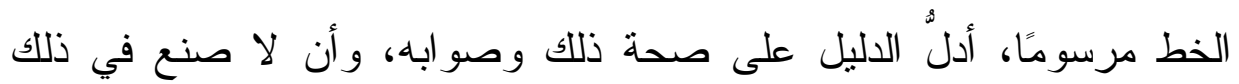

للكاتب (r) (ب).

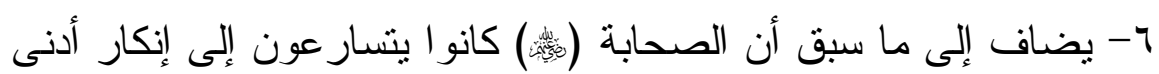
المنكر ات، فكيف يقرّون اللَّحن في القر آن الكريم، بل ويسكتون عنه؟ فلم يوجد حرف أو قر اءة - ثابتة - في كتاب الله إلَّا ولها وجه حسن في اللغة فئ العربية؛ كيف لا وهو الذي نزل بلسان عربي مبين؟(؟).

\section{خامسًا: موقفع المفسرين من هذه المزاعم:}

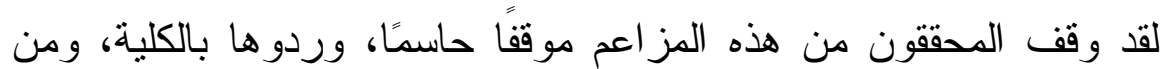
أقو الهم: قال الزمخشري: ولا يلتقت إلى ما زعموا من وقوع اللحن في خط هـ المصحف، وربما التقت إليه من لم ينظر في الكتاب ولم يعرف مذاهب العرب.. و غبي عليه أنّ السابقين الأوّلين كانوا أبعد همة في الغيرة على الإسلام وذبّ

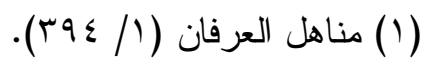

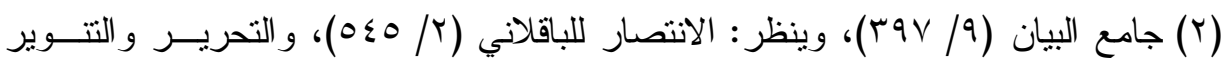

$$
\begin{aligned}
& \text {. (ros/17) } \\
& \text { (ז) رد البهنان (ص: سז). }
\end{aligned}
$$


المطاعن عنه، من أن يتركو ا في كتاب اللَّه ثلمة ليسدّها من بعدهم وخرقا برفوه

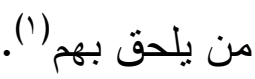
وقال الكرماتي: العجيب قول من قال: هذا غلط من الكاتب، لأن كتاب الله

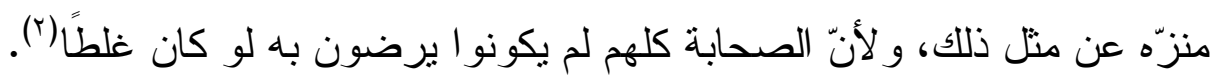
وقال السيوطي: وهذه الآثار مشكلة جدًا، وكيف يظن بالصحابة أنهم يلحنون في الكلام فضلا عن القرآ! ثم كيف يظن بهم في القرآن الذي تلقوه من النبي (ئس كما أنزل وحفظوه وضبطوه و اتقوه! ثم كيف يظن بهم اجتماعهم كلهم على الخطإ وكتابته!ثم كيف يظن بهم عدم تتبههم ورجوعهم عنه! ثم كيف يظن بـ»عثمانه أنه ينهى عن تغييره! ثم كيف يظن أن القراءة استمرت على مقتضى ذلك الخطإ وهو مروي بالتوانر خلفا عن سلف! هذا مما يستحيل عقلاً

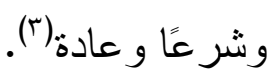

\section{سادسًا: نُوجيه المواضع الأربعة:}

بداية نقول: كل ما ذكره المشككون من أمتلة له وجه صحيح، بل وجوه في اللغة العربية، غاب عنهم معرفتها، وسنذكر بعضًا منها، وذللك من خلال توجيه

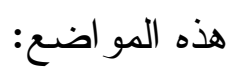

الموضع الأول: قوله:

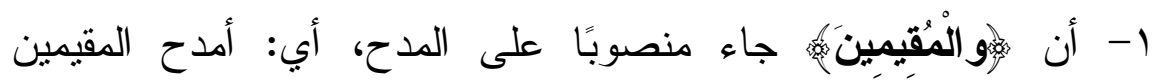

الصلاة.

$$
\begin{aligned}
& \text { (1) الكثاف (1/ (1/ • (1) باختصار • }
\end{aligned}
$$

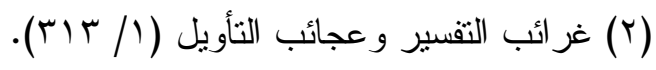

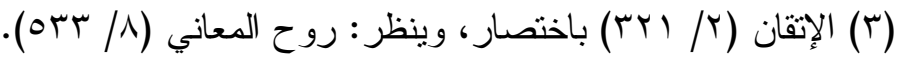


قال مكي: وخبر

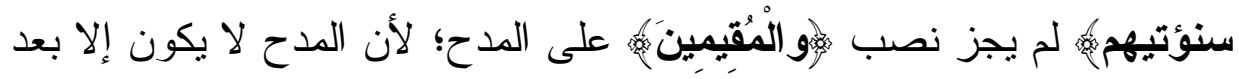

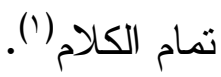
و النصب على المدح وجه من سنن العربية؛ وذلك لأن العرب نتصب على المدح عند تكرار العطف و الوصف، فإذا جرى صفات شتى على موصوف واحد،يجوز الرفع على المدح أو النصب(؟). وقد أيّّ الزجاج هذا الوجه وقال: ولسيبويه و الخليل وجميع النحويين في

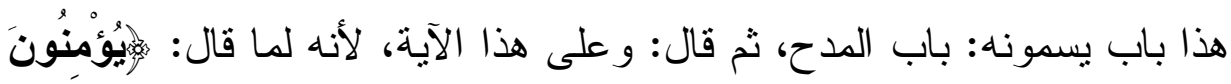

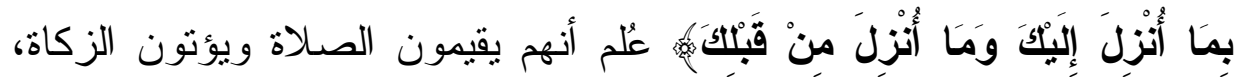

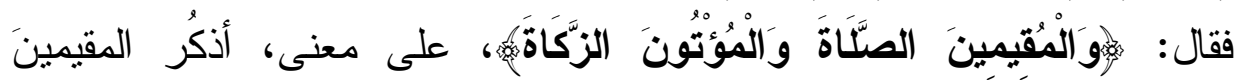

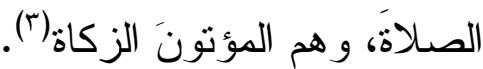

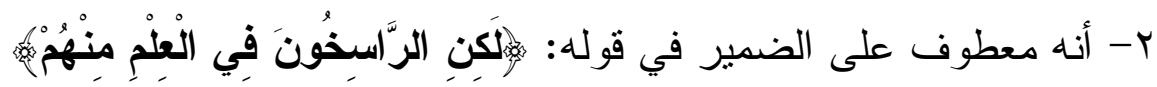
أي: لكن الر اسخون في العلمِ منهم ومن المقيمين الصلاة.

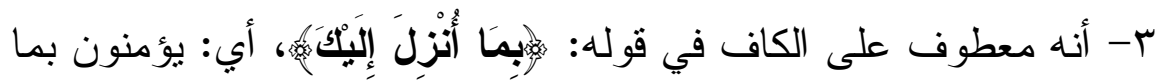

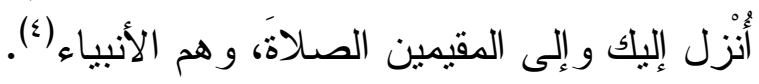

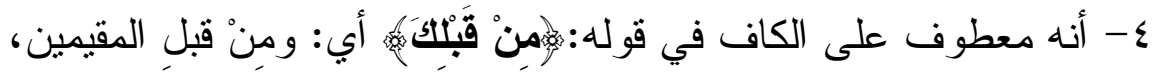

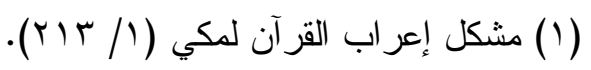

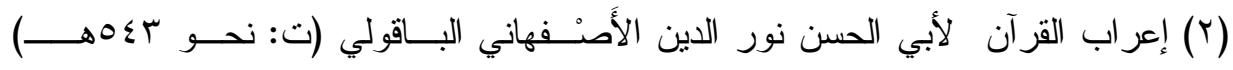

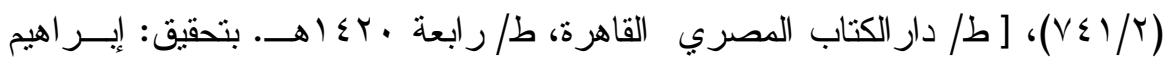
الإبياري].

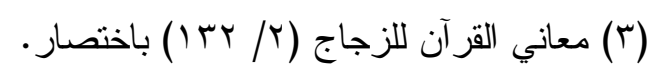

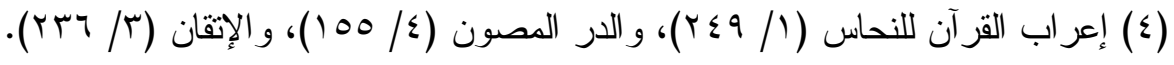


ويعني بهم الأنبياء أيضًا.

0- أنه معطوف على نفس الظرف، ويكون على حَذْف مضاف، أبي: ومن

قبل المقيمين، فحُّف المضاف و أقيم المضاف إليه مقامه ('). وعلى كل : فَّد غاير في الأسلوب ولم يأت على نسق ما سبقه:

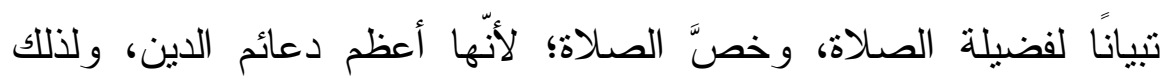

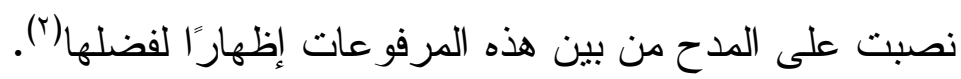

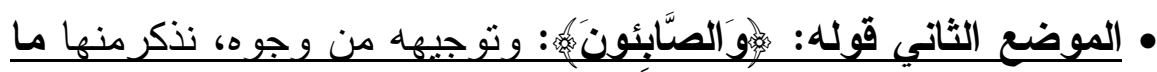

1- أنه مرفوع عطفًا على محل اسم "إنَّه؛ لأنه قبل دخولها كان مرفوعًا

بالابتداء، فلما دخلت عليه لم تغيّر معناه، بل أكدته(؟).

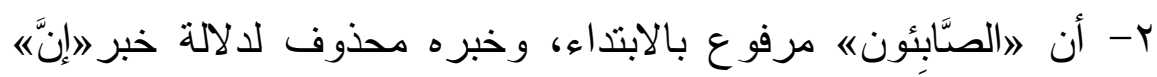

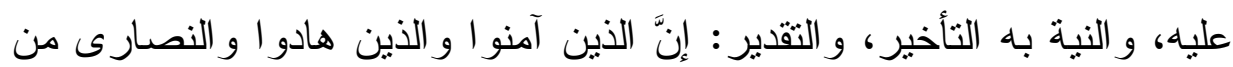
آمن بالله واليوم الآخر وعمل صالحًا فلا خوف عليهم ولا هم يحزنون

و الصابئون كذللك، وهو قول جمهور البصريين الخليل وسييويه وغيرهما(ئ).

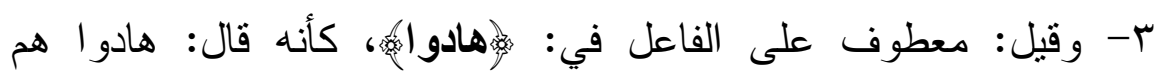

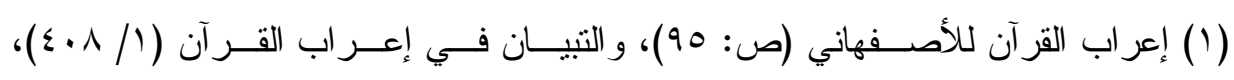

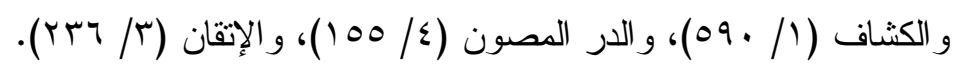

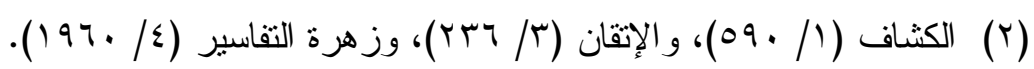

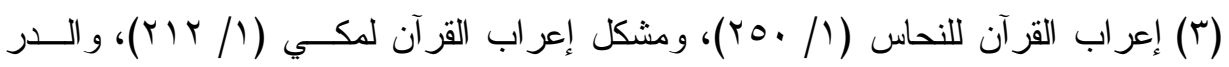

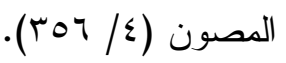

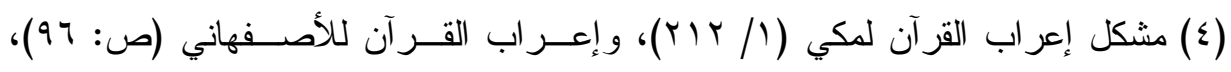

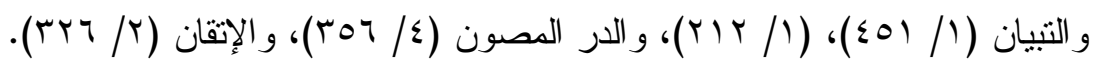


و الصابئون قاله الكسائي (').

ع- أو أنّ "إنَّه" بمعنى نَعم، فهي حرف جواب، و لا محلَّ لها حينئذ،

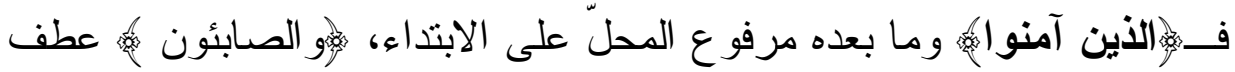

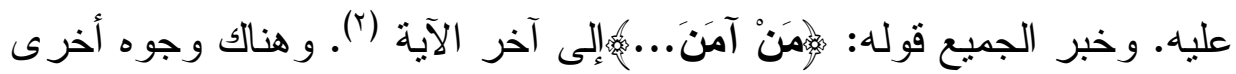
تز اجع في مظانها ().

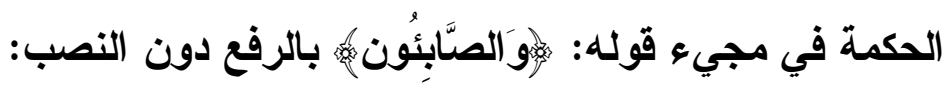

جاء قوله: مع ظهور ضلالهم وزيغهم عن الأديان كلها تقبل توبتهم إن صح منهم الإيمان و العمل الصالح، فغيرهم من أهل الأديان أولى (ء).

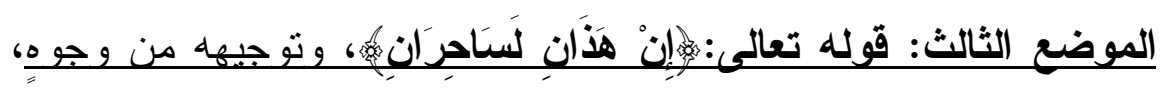
منهـا:

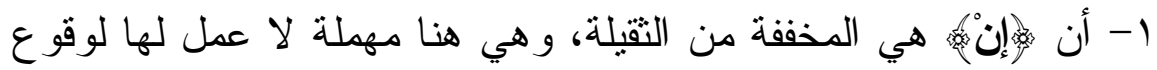
اسم بعدها، و اقترن خبر ها بالام للفرق بينها وبين 》إننه النافية. قال ابن عادل: لما أهملت كما هو الأفصح من وجهها خيف التباسها بالنافية (1) قيل هو خطأ، فالصابئ على هذا القول يشارك اليهودي في اليهودية، وليس كذلك، فــإن

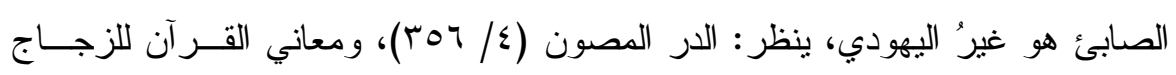

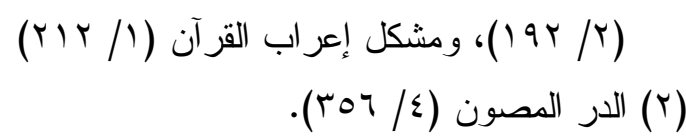

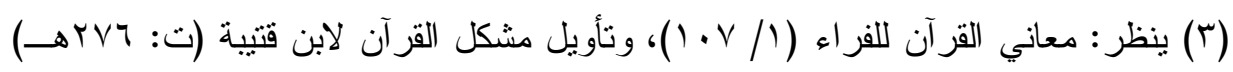

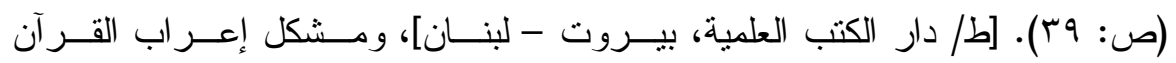

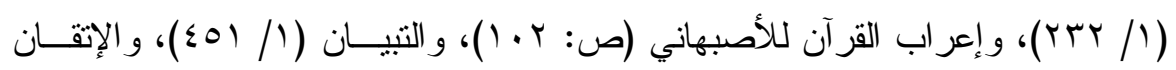
(rrT/r)

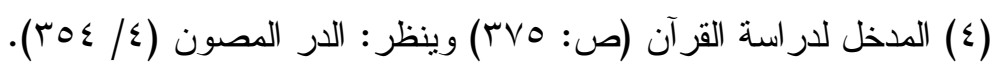




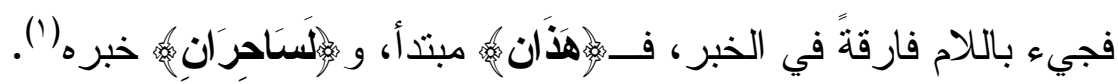
r- أنها جاءت على بعض لغات العرب: بني الحارث وبني الهُجَيْم وبني

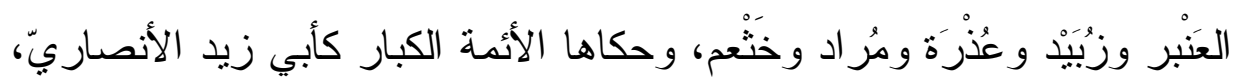
و الكسائي، ولها شو اهد كثيرة، مثل قول الثناعر :

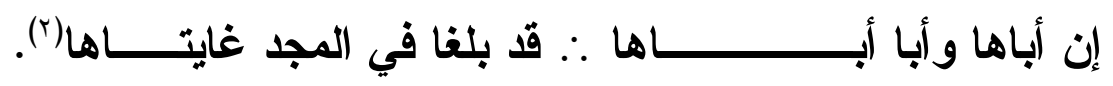
وهم الذين يُلزمون المثثى الألف كالمقصور في أحواله الثلاث، ويقدرون إعر ابه بالحركات وهي لغة مشهورة، يقولون: مررت برجلان، وقبضت منه در همان.

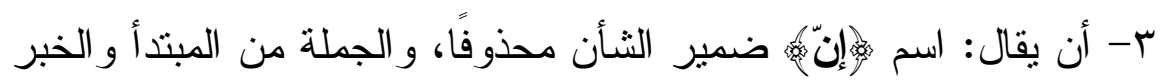

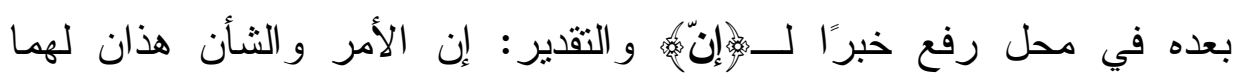
ساحر ان.

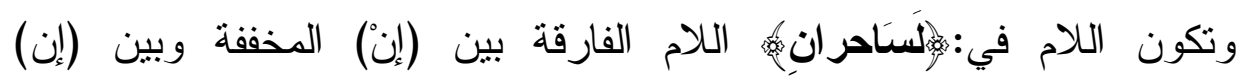

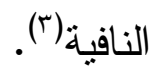

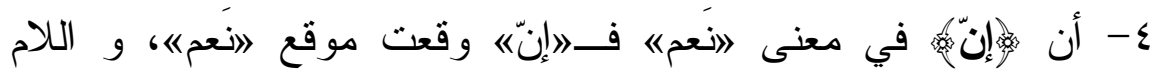
وقعت موقعها، و المعنى: نعَم هذانِ لهُما ساحرِان، وذللك أن خطباء الجاهلية

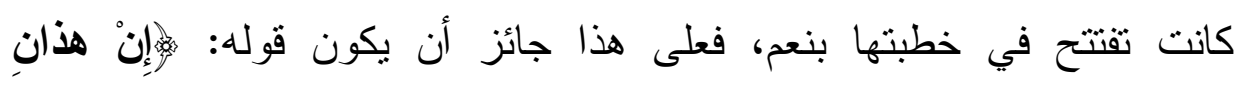

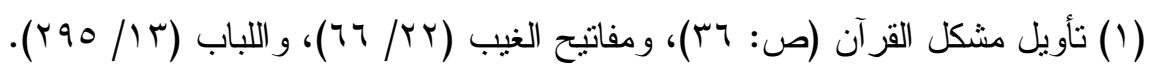

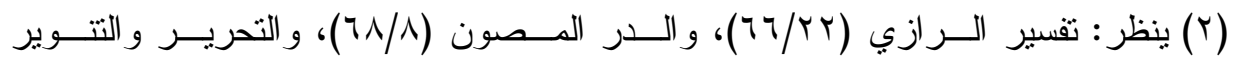
(YOr/ T T)

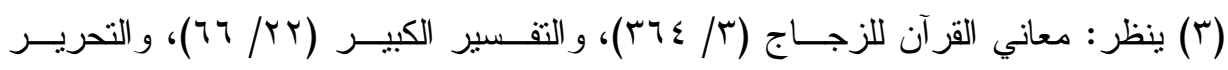

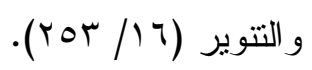




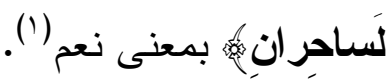

وقد استحسن هذا الوجه بعض اللغويين، ومنهم الزجاج، و المبرد(؟).

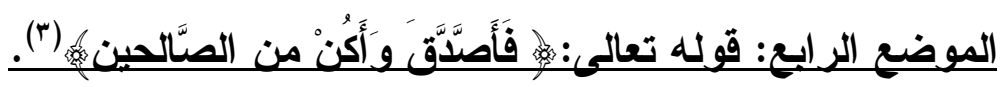

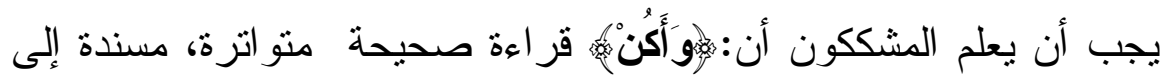

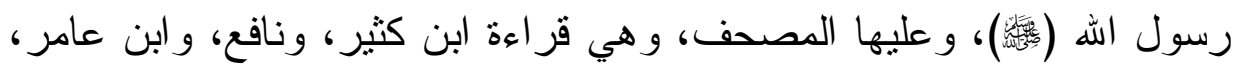

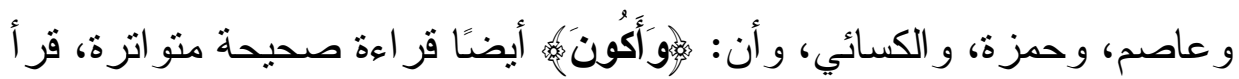

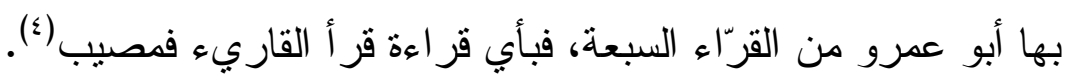

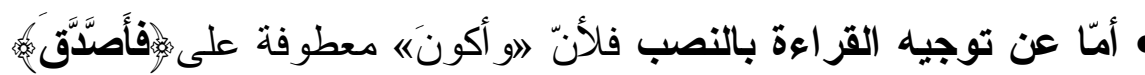

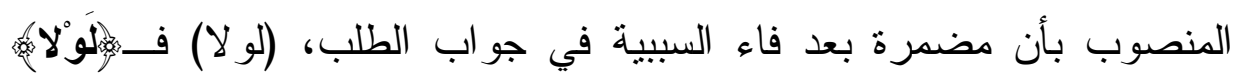
حرف تحضيض بمعنى هلاً.

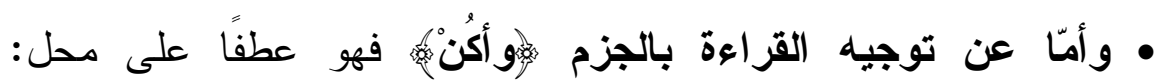

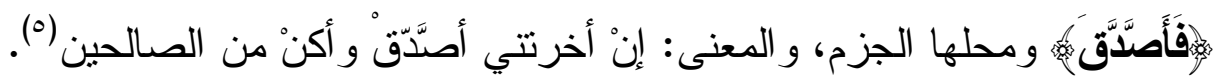

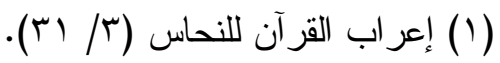

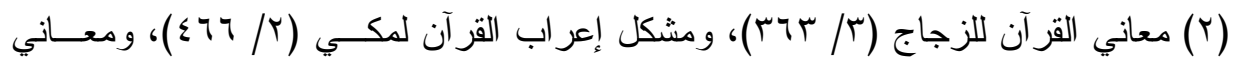

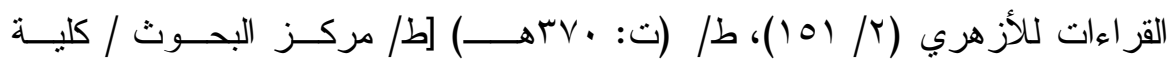

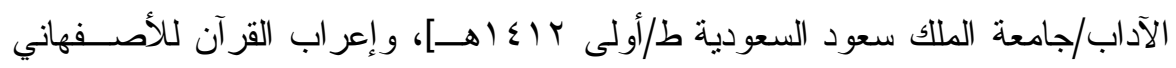

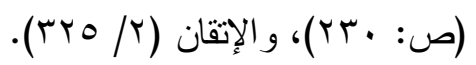

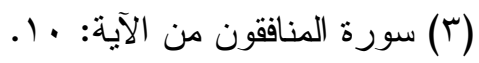

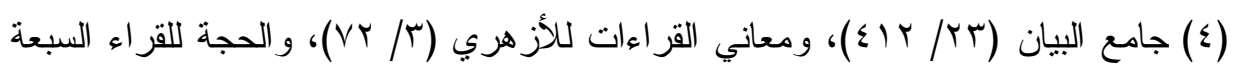

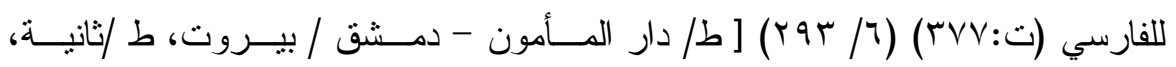

$$
\text { [) }
$$

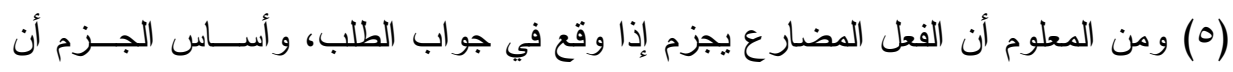

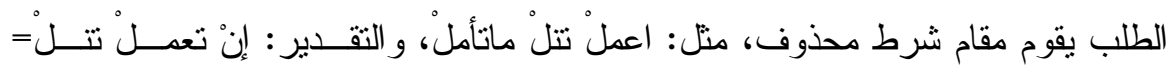


ومن خلال ما سبق: تبين لنا أن كل ما ذكره المشككون من أمثلة له وجه

صحيح، بل وجوه في اللغة العربية، غاب عنهم معرفتها، لجهلهم بأساليب القر آن البديعة.

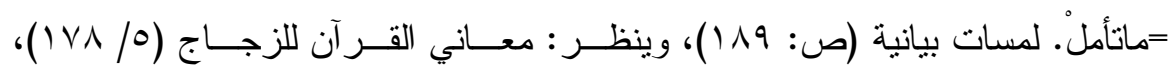

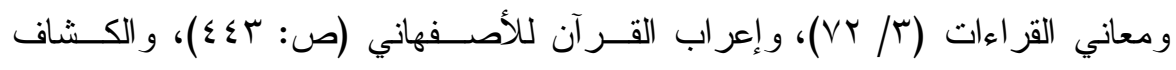

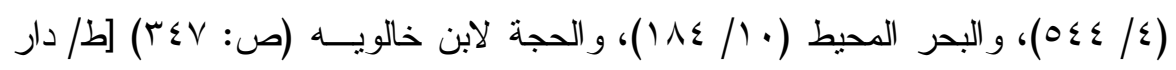

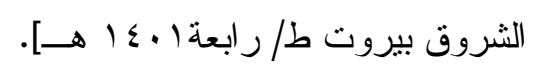




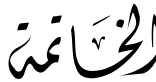

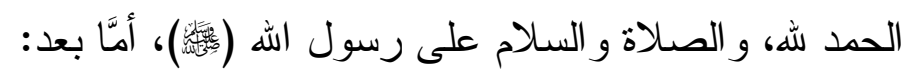

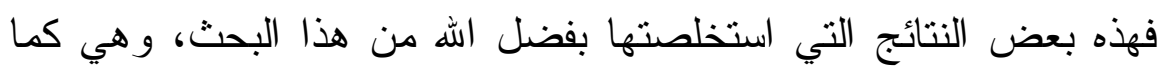

1- أن كل المز اعم التي تمَّ دراستها في هذا البحث مردودة، و لا يعوّل

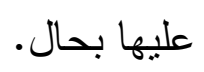

r- أن هذه المز اعم و الثبهات تعدُّ خيطًا من الخيوط الضعيفة التي نسج

بها الطاعنون في القر آن شبههم و افتز اءاتهم.

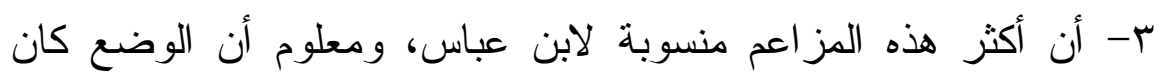

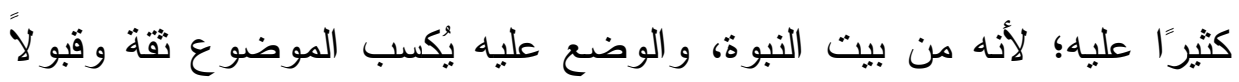

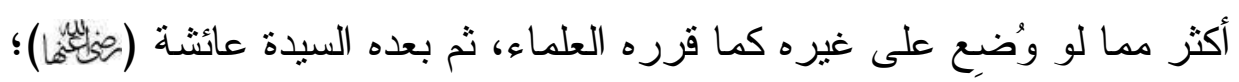
لأنها زوجة النبي (الئلمنّ).

ـ - أن سبب وضع هذه الفي المرويات هو الحقد و الكر اهية للإسلام.

ه- أن الهدف من إثارة هذه المز اعم من حين لآخر هو لتشكيك المسلمين

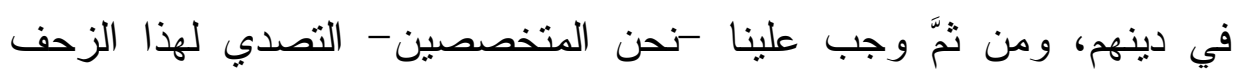
الخبيث.

1- أنّ كثيرًا مما غاب فهمه عن هؤلاء الز اعمين - في إعراب القرآن -

$$
\text { يدركه بعض الطلاب في المعاهد الأزهرية، و المدارس. }
$$

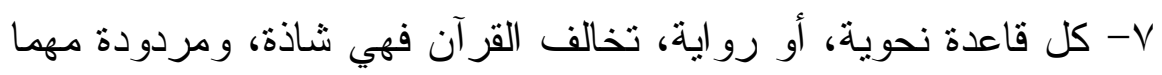

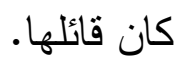

1- أن هذه المزاعم و الثبه ليست وليدة اليوم ولكنها قديمة منذ زمن

الصحابة، ولكنها فيكل فترة تلبس ثُبًا جديدًا. 
9- أن من مناهج المشككين في القرآن اعتمادهم على الر اويات الضعيفة، و الآثار الواهية التي ذكِرت في بعض الكتب بحسن نية، فاستغلوها لتحقيق مآربهم و أهد افهم. • 1- أن المحققين من المفسرين لم يغفلو ا عن كثير من هذه الروايات، بل ذكرو ها و نقدو ها و علقو ا عليها، وبيَّنو ا حالها. 11- أن هناك روايات متعددة تطعن في القرآن تحتاج إلى أن تدرس ولى در اسة حديثية علمية تجمع كل طرق الرو ايات، و الحكم عليها مفصّلًا حتى يعلم الجميع حالها. 


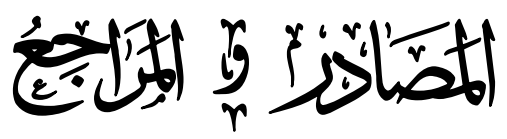

\section{أولاً: القرآن|لكريع.}

\section{ثانيًا: الكتب الأخرى.}

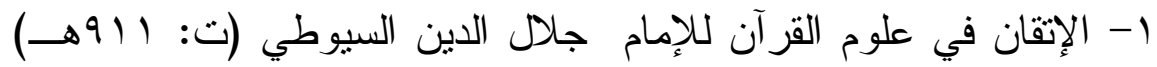

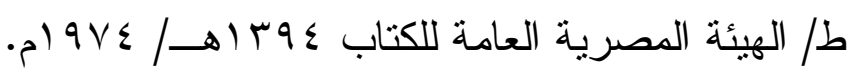

r- أحكام القرآن للقاضي للإمام أبي بكر بن العربي المالكي

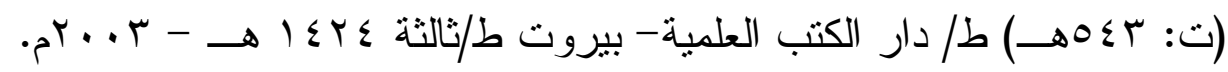
ب- إرشاد العقل السليم إلى مزايا الكتاب الكريم لأبي السعود محمد

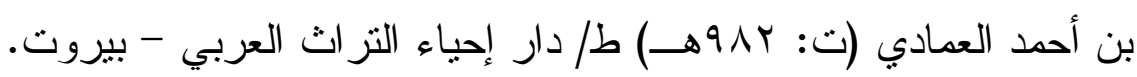
ع- أضواء البيان في إيضاح القرآن بالقرآن لمحمد الأمين الثنقيطي

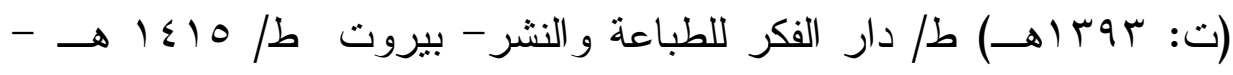
. $) 990$

0- إعر اب القرآن لأبي جعفر النحاس (ت: ^بrهـ) طا منشور ات محمد

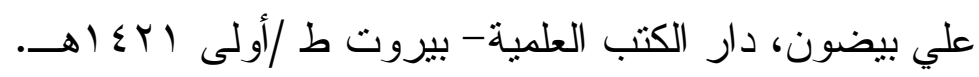

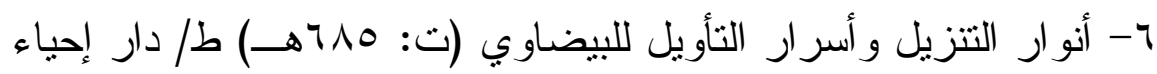

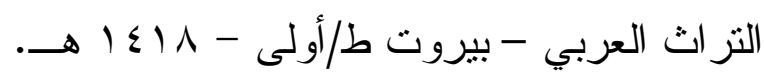

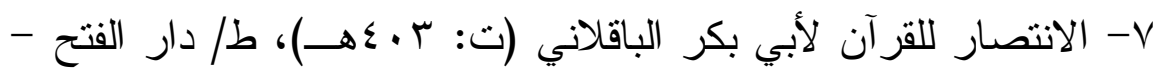

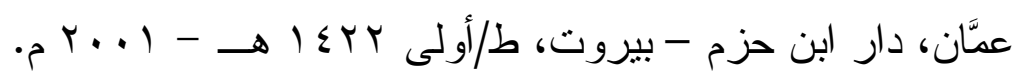

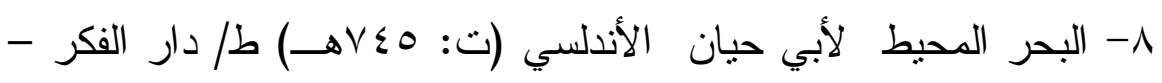
بيروت · ب أ هـــ 
9- البحر المحيط في أصول الفقه،لإمام بدر الدين محمد الزركثي

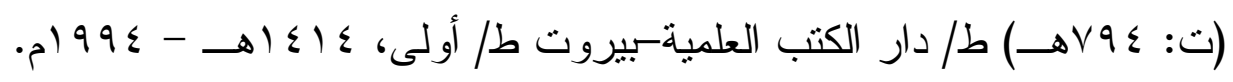
• 1- تاريخ الإسلام ووفيات المشاهير والأعلام لشمس الدين بن قَايْماز

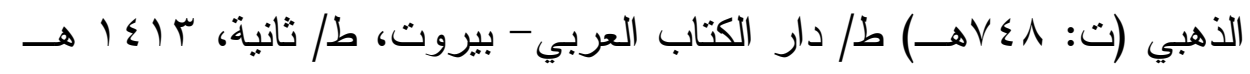
. $1994-$

11 - تأويلات أهل السنة لأبي منصور الماتريدي (ت:سبسهـ) طا دار

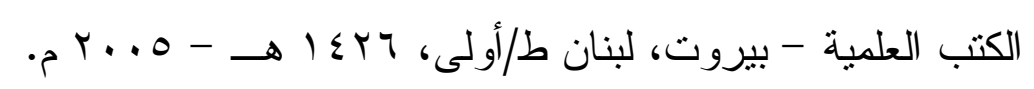

r ا - التبيان في آداب حملة القرآن للإمام محيي الدين يحيى بن شرف له النووي (ت: TVT هـ) ط/دار ابن حزم للطباعة و النشر - بيروت، لبنان

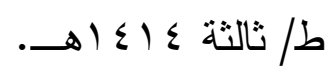

با- التبيان في إعراب القرآن لأبي البقاء عبد الله بن الحسين العكبري (ت: 7 (77هـ) المحقق: علي محمد البجاوي طاعيسى البابي الحلبي وشركاه. ع ا- التحرير والتتوير لسماحة الثيخ /محمد الطاهر ابن عانثور التونسي

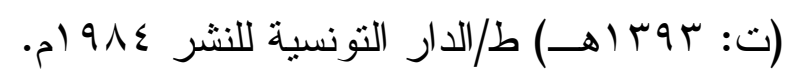
10

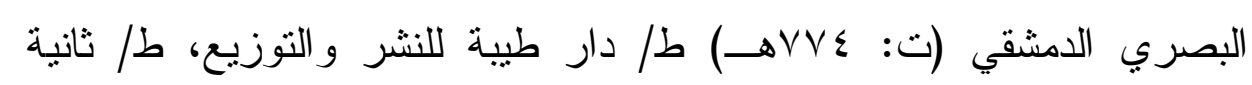
. $1999-\rightarrow 1 \leq r$.

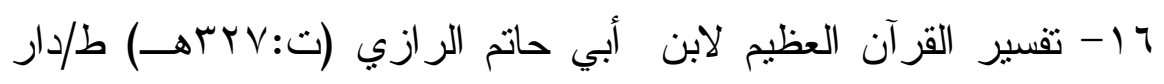

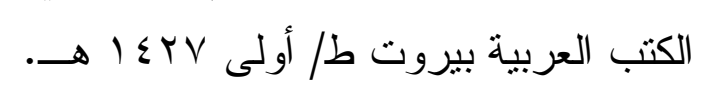

V ا- التفسير القر آني للقرآن للأستاذ/عبد الكريم الخطيب طا دار دار الفكر

$$
\text { العربي - القاهرة. }
$$


1 ا - التفسير من سنن سعيد بن منصور لسعيد بن منصور (ت TrVAه)،

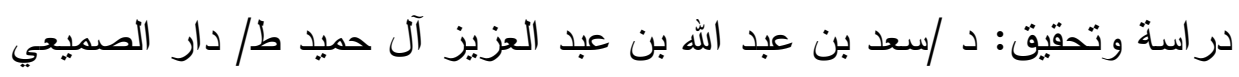

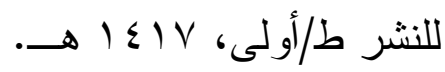

9 19 تقريب التهذيب لابن حجر(ت: 10rهــ) ط/دار الرشيد سوريا

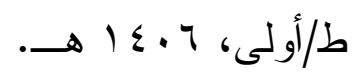

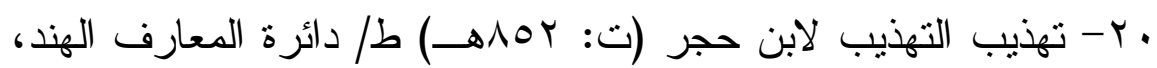

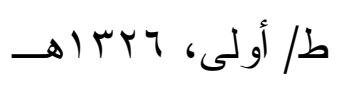

اץ- تهذيب اللغة لأبي منصور الأزهري (ت: • Vrهـ) ط/ دار إحياء

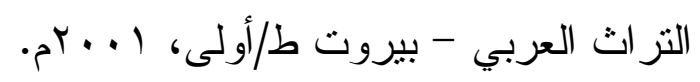

r ب- جامع البيان في تأويل آي القرآن للإمام الطبري (ت: · • اسهــ)

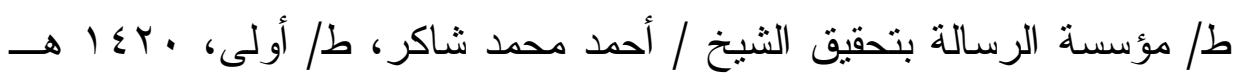

$$
\text { . } r \text {...- }
$$

بr- جامع المسانيد و الستُنْ الهادي لأقوم سَنن للحافظ ابن كثير

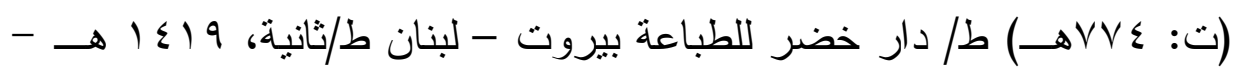

$$
\text { - }) 991
$$

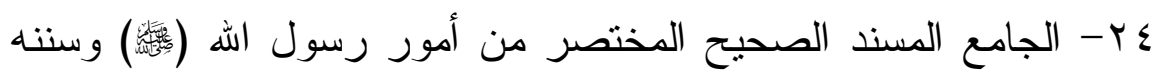

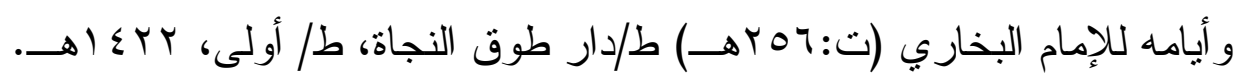

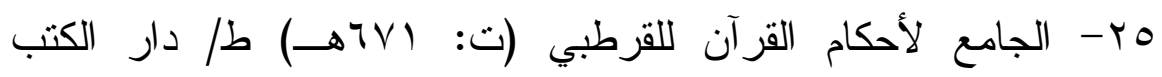

$$
\text { المصرية - القاهرة. }
$$

جr- جمال القراء وكمال الإقراء لأبي الحسن علم الدين عليّ بن محمد

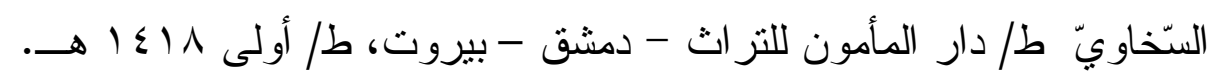


لrV بن يوسف المعروف بالسمين الحلبي (ت:187هـ) ط/دار القلم -دمشق /ط/

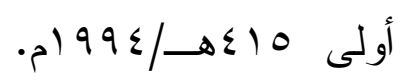

^ץ- الدر المنثور في التفسير بالمأتور لجلال الدين السيوطي

$$
\text { (ت: 1) }
$$

qץ- ديوان الضعفاء و المتروكين وخلق من المجهولين ونقات فيهم لين،

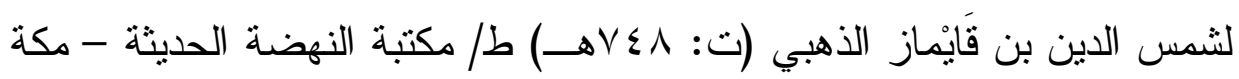

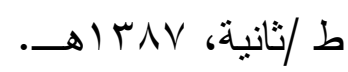
• ب- رسم المصحف دراسة لغوية تاريخية لغانم قدوري الحمد ط/ دار

$$
\text { عمار ، عمان، طا أولى. (رسم. }
$$

اس - رسم المصحف ونقطه ا.د/عبد الحي الفرماوي طم/ المكتبة المكية، مكة

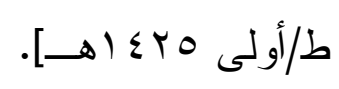

rr- روح المعاني في تقسير القرآن العظيم و السبع المثاني للإمام شهاب الدين الآلوسي (ت: • • إهـ) ط/دار الكتب العلمية - بيروت ط/أولى $\rightarrow 10$

بr-ز اد المسير في علم التفسير لأبي الفرج ابن الجوزي (ت:09هــ):

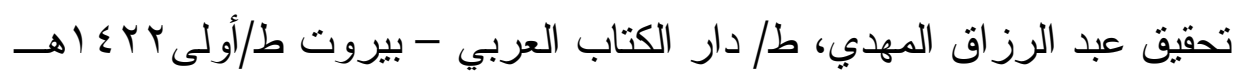

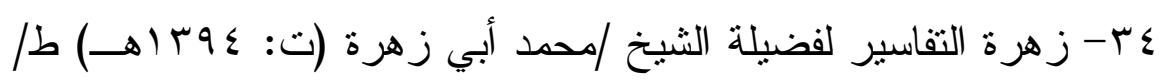

$$
\text { دار الفكر العربي. }
$$

هب- السر اج المنير في الإعانة على معرفة بعض معاني كلام ربنا الحكيم الخبير لمحمد بن أحمد الخطيب الثربيني (ت: 9VVهـ) طا مطبعة بولاق

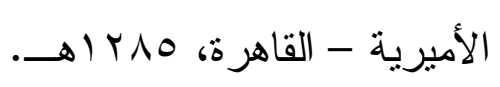


جس- سنن أبي داوود للإمام أبي داوود سليمان بن الأشعث الأزدي

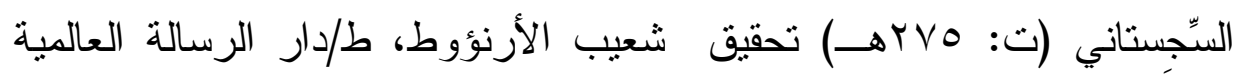

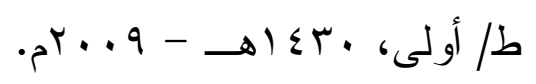

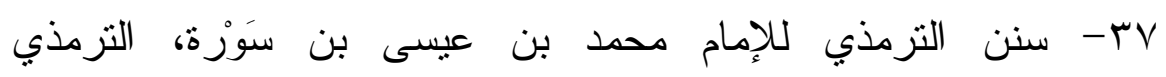

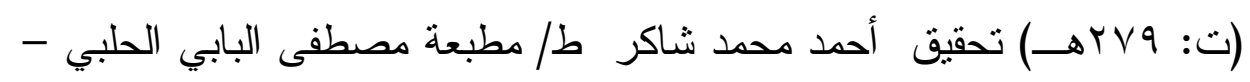

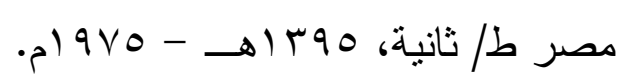

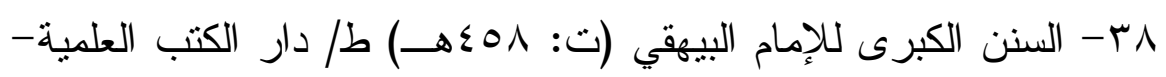

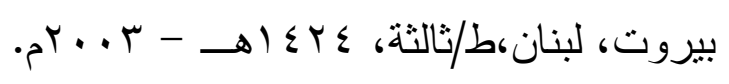

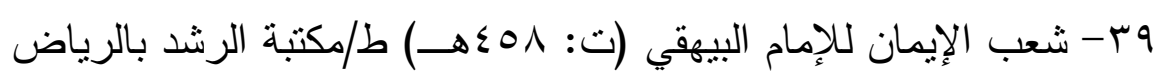

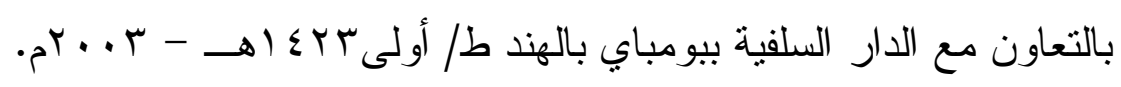

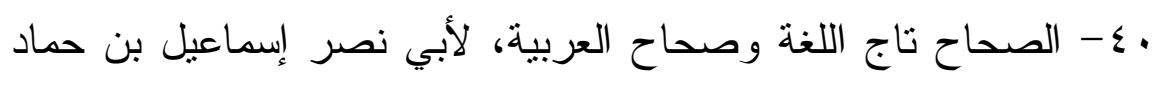

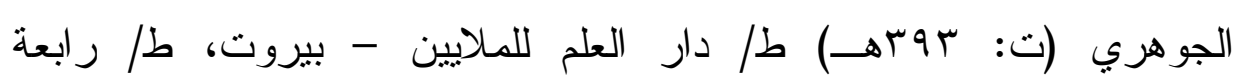
. $19 \wedge v-\rightarrow \Sigma \cdot v$

اء- صحيح مسلم للإمام مسلم (ت: آبهـ) طادار إحياء التزاثبيروت.

r r غاية النهاية في طبقات القراء لأبي الخير محمد بن يوسف ابن الجزري، (ت: سبرهــ) طا مكتبة ابن تيمية. بـ - غر ائب التفسير وعجائب التأويل لمحمود بن حمزة الكَرْماني طا دار لئه القبلة للتقافة الإسلامية - جدة مؤسسة علوم القر آن - بيروت. ع - فتح الباري للحافظ/ ابن حجر العسقلاني الثافعي، ط/دار المعرفة -

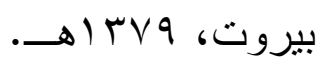


0ـ- فتح البيان في مقاصد القرآن، لأبي الطيب محمد صديق خان

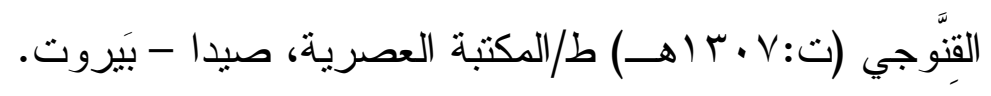

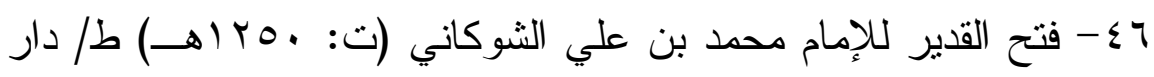

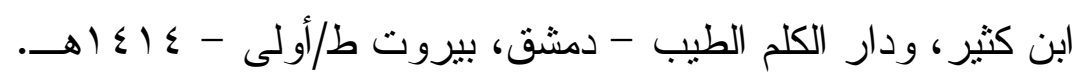

צ V

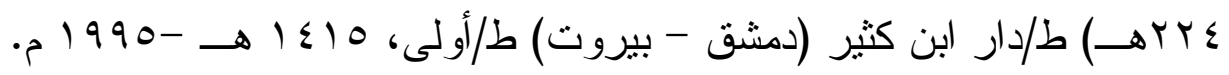

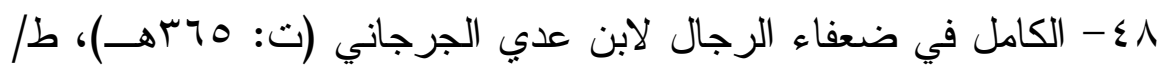

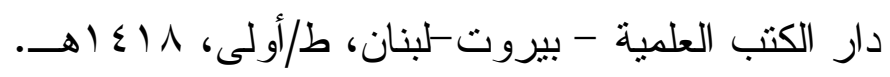

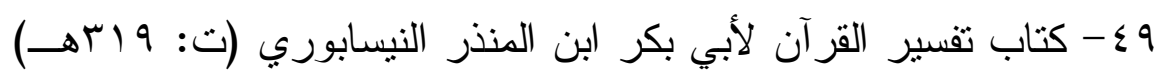

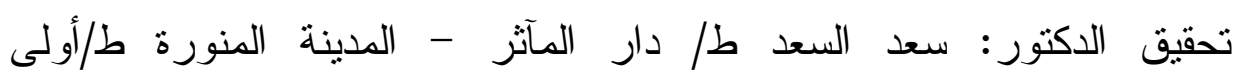

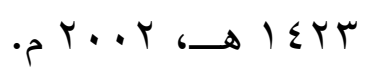

•- الكثاف عن حقائق غوامض التنزيل وعيون الأقاويل في وجوه التأويل للزمخشري (ت: ^مهـــ طـ/ دار الكتاب العربي - بيروت طا ثالثة $\rightarrow 1 \leqslant \cdot V$

10- لباب التأويل في معاني التنزيل للخازن (ت: إعهـ) طا دار

$$
\text { الكتب العلمية - بيروت طأولى. }
$$

ror- اللباب في علوم الكتاب لابن عادل الحنبلي (ت:

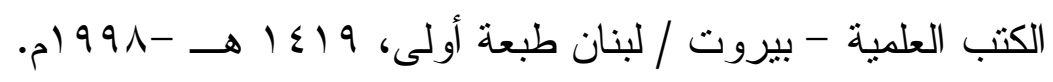

rه- لسان العرب لابن منظور (ت: I1 الهـ ) طادار صادر - بيروت-

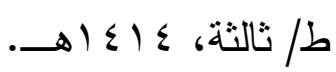

ع - لمسات بيانية في نصوص من التنزيل، د/ فاضل السامر ائي ط ط/ دار

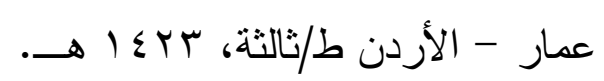




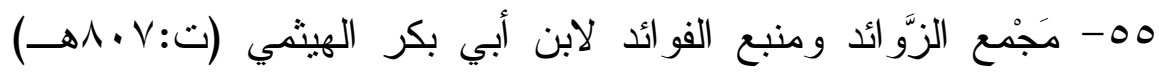
ط/دار المأمون للتر اث. 7ه- المحتسب في تبيين وجوه شو اذ القراءات و الإيضاح عنها لأبي الفتح عثمان بن جني (ت: rوسهـ)، ط/ وزارة الأوقاف-المجلس الأعلى للشئون

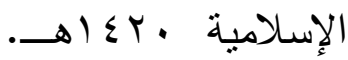

- المحرر الوجيز في تقسير الكتاب العزيز، لأبي محمد عبد الحق بن غالب بن عطية الأندلسي المحاربي (ت: rی\&هــ) طا دار الكتب العلمية -

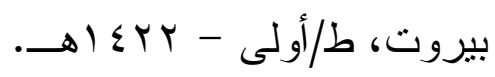

1ه- المدخل لار اسة القرآن الكريم للشيخ /محمد بن محمد بن سويلم أبي

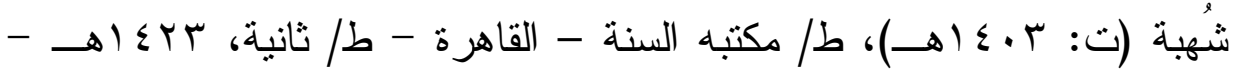

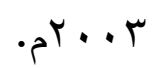

9ه- مرقاة المفاتيح شرح مشكاة المصابيح لأبي الحسن نور الدين الملا

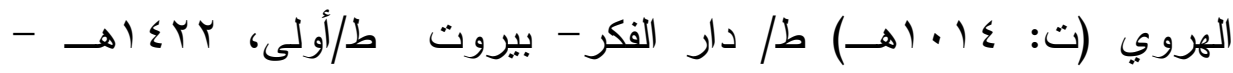
$\cdot r \cdot r$

• ؟- المستدرك على الصحيحين للحاكم (ت: 0 . عهـ) ط/دار الكتب

$$
\text { العلمية بيروت طأولى. }
$$

اج-المسند، للإِمام أحمد بن حنبل الثيباني (ت: (

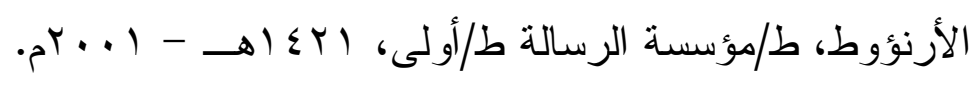

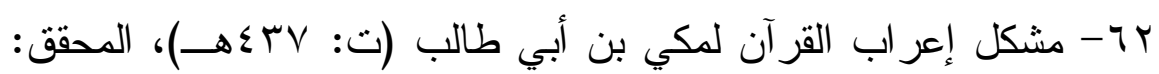

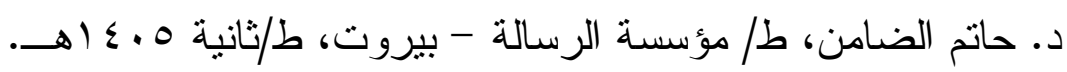


با7- المصاحف لأبي بكر بن أبي داود، عبد الله بن سليمان بن الأشعث

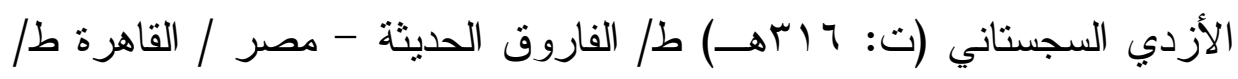

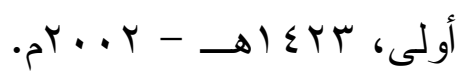

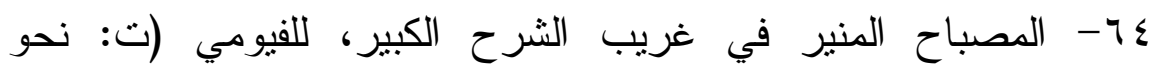
طـ طا المكتبة العلمية - بيروت.

ه7- معالم التنزيل في تفسير القرآن لأبي محمد الحسين بن مسعود

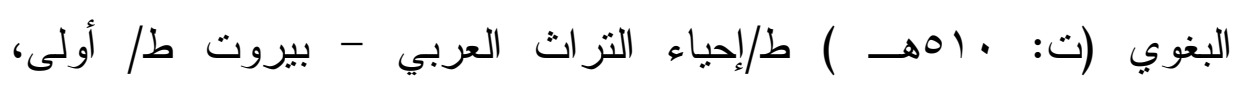
$\rightarrow$. $1 \leqslant r$.

ד - معاني القرآن لأبي جعفر النحاس (ت: ^سזهــ) تحقيق /محمد علي

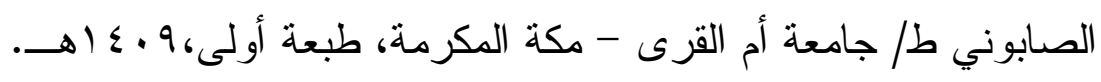

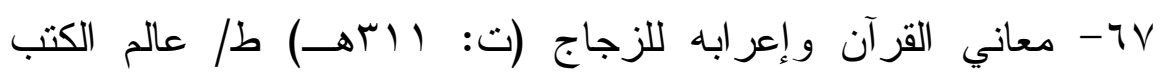
بيروت ط/ أولى 1 ·ـ اهــ.

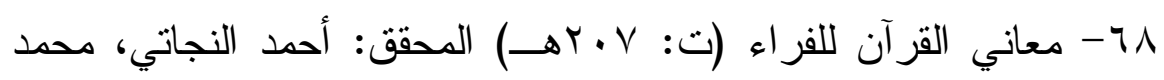
علي النجار، عبد الفتاح الثلبي ط/الدار المصرية للتأليف والتزجمة - مصر

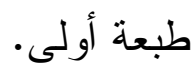

9 79- المعجم الكبير للطبر اني (ت: • بسهـ) ط/مكنبة ابن تيمية، القاهرة طا ثانية.

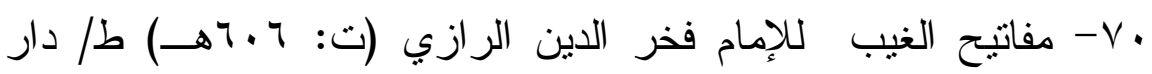

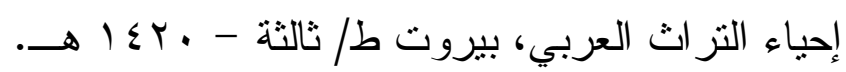

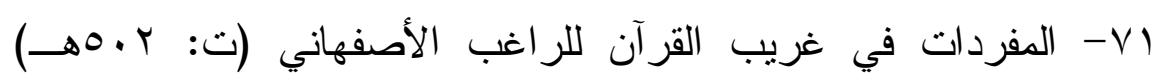

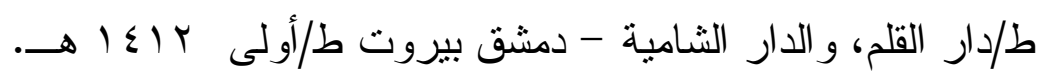




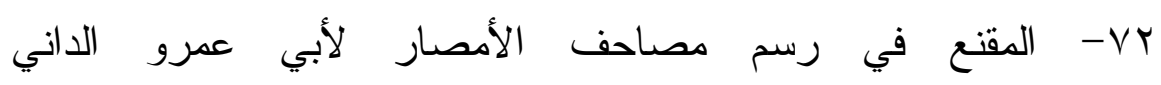

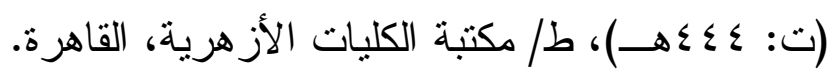

r . $\rightarrow$ I

ع - مناهل العرفان في علوم القرآن للشيخ / محمد عبد العظيم الزُرْقاني

(ت: جب ا هــ) ط/ مطبعة عيسى البابي الحلبي وشركاه، ط/ ثالثة.

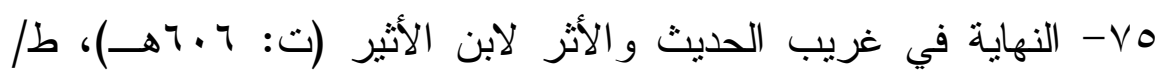

$$
\text { المكتبة العلمية - بيروت. }
$$

TV- و العيون لأبي الحسن الماوردي (ت: •.0ءـــ طادار الكتب العلمية 
فهرس الموضوعات

\begin{tabular}{|c|c|}
\hline |لصفحة & الموضوع \\
\hline r & (المقدمة \\
\hline$\varepsilon$ & أسباب اختيار الموضوع وأهميته \\
\hline ○ & حدود البحث \\
\hline$\checkmark$ & تمهيخ \\
\hline $\mathrm{v}$ & مسائل متعلقة بالبحث \\
\hline V & المسألة الأولى: مصطلحات البحث \\
\hline 9 & المسألنة الثانية: حجّ بـة قول الصحابيّ، وقول التابعى \\
\hline 11 & المسألثة الثالثة: هل يلزم من صحة الستَّد صحة المتْن؟ \\
\hline Ir & المبحث الأول: كُّاب المصحف و عنايتهم بالقر آن \\
\hline rr & المبحث الثاني: ما ورد حول خطأ الكاتــب فــي تبــديل كلمــات \\
\hline rr & المطلب الأول: ما ورد في تبديل كلمات بكلمة \\
\hline$\mu^{\prime}$ & المطلب الثاني: ما ورد حول خطأ الكاتب في تبــديل كلمـــة \\
\hline 01 & المطلب الثالث: ما ورد حول تبديل كلمة بحرف \\
\hline
\end{tabular}




\begin{tabular}{|c|c|}
\hline$\Delta V$ & المطلب الر ابع: ما ورد حول خطأ الكاتب في تبديل بعـض \\
\hline v. & المبحث الثالث: ما ورد حول الزيادة أو النقص \\
\hline v. & المطلب الأول: ما ورد حول زيادة حرف \\
\hline$V_{7}$ & المطلب الثاني: ما ورد حول نقص كلمة \\
\hline$\wedge 1$ & المبحث الر ابع: ما ورد حول خطأ الكاتب من الناحية النحوية \\
\hline 90 & 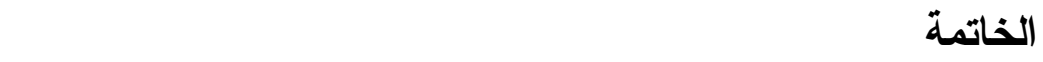 \\
\hline $9 V$ & المصادر والمر اجع \\
\hline $1 \cdot 7$ & فهرس الموضوعات \\
\hline
\end{tabular}

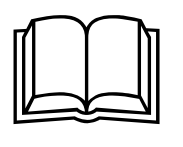

